(NASA-CR-174709) ADVANCED ON-STTE PONER

PLANT DEVELOEMENT TECHNCLOGY FFCGAM Annual

Report,: 19.83: (United. Technologies Corp.).

155 P HC AO8/ME LO1
CSCL $10 \mathrm{~B}$
DOE/NASA/0289-1

NASA CR-1.747.09

PSD FCR-5715

N86-25040

\title{
Advanced On-Site Power Plant Development Technology Program
}

\section{Annual Report}

United Technologies Corporation UW Wh3 4588
Power Systems Division

Fuel Cell Operations

South Windsor, Connecticut

June 1984

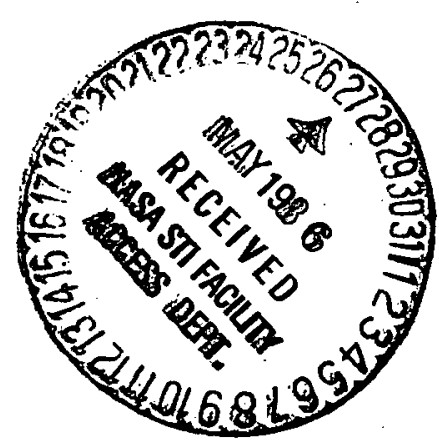

Prepared for

National Aeronautics and Space Administration

Lewis Research Center

Cleveland, Ohio 44135

Under Contract DEN3-289

for

U.S. DEPARTMENT OF ENERGY

OFFICE OF FOSSIL ENERGY

MORGANTOWN ENERGY TECHNOLOGY CENTER

Under Interagency Agreement DE-Al-21-80ET17088 
DOE/NASA/0289-1

NASA CR-174709

PSD FCR-5715

\section{Advanced On-Site Power Plant Development Technology Program}

\section{Annual Report}

United Technologies Corporation

Power Systems Division

Fuel Cell Operations

June 1984

Prepared for

National Aeronautics and Space Administration

Lewis Research Center

Under Contract DEN3-289

for

U. S. DEPARTMENT OF ENERGY

Morgantown Energy Technology Center 


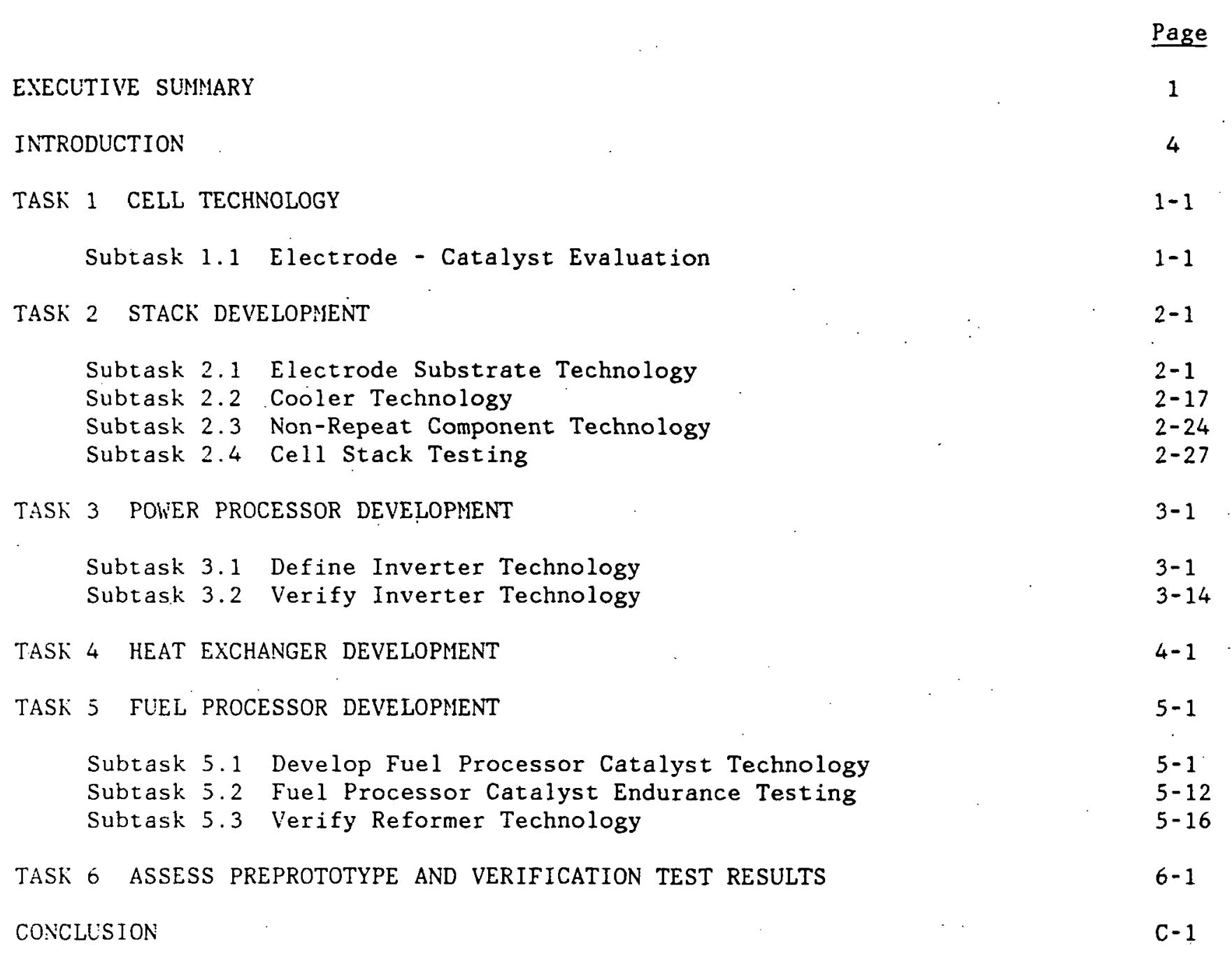




\section{ILLUSTRATIONS}

1-1

1-2

$1-3$

$1-4$

$1-5$

$1-6$

$1-7$

$1-8$

$1-9$

2. 1-1

2. $1-2$

$2.1-3$

$2.1-4$

$2.1-5$

$2.1-6$

$2.2-1$

$2.3-1$.

$2.4-1$

$2.4-2$

$2.4-3$

$2.4-4$

$2.4-5$

$2.4-6$

$2.4-7$

$2.4-8$

$2.4-9$

$2.4-10$

3. $1-1$

3. $1-2$

3. $1-3$

3. $2-1$

3. $2-2$

3. $2-3$

$4-1$

$4-2$

$4-3$

$4-4$

$4-5$
Components of Subscale Cell Excluding Gaskets and Seals

View of Stand Used to Test Subscale Cells

Performance History of Series I Platinum Catalyst Cells

Performance History of Series I "6" Alloy Catalyst Cells

Performance History of Series I "18" Alloy Catalyst Cells

Performance History of Series II Cells

Performance History of Series II Cells

Performance History of Cell 3638

Stack Cell Performance Compared to Subscale Cell Performance

Pore Distribution of Dual Porosity Substrates

Schematic of Diffusion Apparatus

Effective Diffusion Coefficient vs. Percent Electrolyte Fill for

Dual Porosity and Single Porosity Substrates

Median Pore Size vs. Weighted Fiber Diameter

Breadth of Pore Distribution vs. Weighted Fiber Diameter

Low Cost Substrate Properties Compared to Properties of

Substrates Used in Power Plants

Test Stand Schematic

Acid Replenishment Test Rig

Stack Assembly Prior to Thermal Insulation

Average Cell Voltage vs. Current Density

Cell Stack Performance History

Cell Performance vs. Cell Position

Reactant Gas Utilization vs. Average Cell Voltage

Anode and Cathode Performance Gain for Pure Reactants

Reactant Gas Cross-Leakage Test

iR vs. Cell Position

Cel1 Temperature Distribution

Axial Load vs. Test Time

$1-4$

$1-5$

$1-6$

$1-7$

$1-8$

$1-13$

$1-15$

$1-16$

$1-19$

2-3

$2-5$

2-6

2-10

$2-11$

$2-15$

$2-22$

$2-28$

$2-31$

$2-33$

$2-34$

$2-35$

$2-36$

$2-37$

$2-39$

$2-40$

$2-41$

$2-42$

$200-\mathrm{kW}$ Inverter System $3-3$

Output Transformer Outline

$3-7$

$3-9$

$3-17$

$3-21$

$3-22$

Schematic of Bridge Logic Control

hirewrap Waveform Processor Board

$4-6$

$4-7$

$4-11$

$4-12$

$4-13$ 


\section{ILLUSTRATIONS (Cont' d)}

\section{Figure}

$\underline{\text { Page }}$

5.1-1 Subscale Reactor Schematic

$5 \cdot 1-2$ Subscale Reactor and Furnace

$5.1-3$

$5.1-4$

$5.1-5$ Low $\triangle P$ Catalysts Reform Conversion

Reform Conversion with Reduced $\Delta P$ Catalysts

Performance of Catalysts at $2 x$ Design Mass Flux

Subscale HDS Test Reactor Schematic

$5-13$

Catalyst Endurance Train for On-Site Fuel Processor

$5-15$ 200-kW Development Reformer Performance Estimate

$5-18$

Test Set-Up Used for Evaluating Commercial Burner

$5-20$

Commercial Reformer Burner Candidate

$5-21$

$5 \cdot 3-3$

Water Flow Table with Burner Model Set Up for Test

5-23 


\section{TABLES}

Table

$\underline{\text { Page }}$

$1-1$

Series I Cells - Peak Performance Data

$1-10$

$1-2$

Series I Cells $-\mathrm{H}_{2} / \mathrm{O}_{2}$ Performance with Time

$1-11$

$1-3$

Identification of Series II Cells

$1-12$

$1-4$

Subscale Cell Tests of Electrodes of the Types Used in the 30-Cell

$1-17$

Stack

$2.1-1$

$2.1-2$

$2.1-3$

$2.3-1$

$3.1-1$

$3.1-2$

$3.1-3$

3. $1-4$

$3.2-1$

3. $2-2$

$3.2-3$

$4-1$

$+-2$

$4-3$

$5.1-1$

$5.1-2$

$5.1-3$

$6-1$

$0-2$

$0-3$

$0-4$

$0-5$
Fiber Length-Diameter Test Matrix

Effect of Thermal Conductivity on Power Section Cost

Variation of Stack Cost with Electrical Conductivity

Comparison of Electrolyte Addition Approaches

Calculated Inverter Efficiency

Auxiliary Commutation for Surge Effect on Efficiency

Thyristor Performance Projections

Bridge Cooling Summary

Brassboard Inverter Half Pole Thermal Test Results

Series Reactors Specification

Bridge Logic Status Summary

Acid Condenser Heat Exchanger Test Results

Water Spray. Acid Condenser Test Results

Comparison of Acid Removal Candidates

Wall Temperature Profiles

Performance of Low $\triangle \mathrm{P}$ Catalysts

Experimental Data on Activity Screening of Low $\Delta \mathrm{P}$ Catalysts

Percent Failures by Cause

Power Plant Shutdowns Due to Process Failures

Power Plant Shutdowns Due to Inadequate Components

Power Plant Shutdowns Due to Component Failures

Power Plant Shutdowns Due to Human Errors
$2-8$

$2-12$

$2-13$

$2-26$

$3-5$

$3-8$

$3-11$

$3-13$

$3-16$

$3-18$

3-23

4-8

4-15

4-17

5-8

5-10

5-11

6-6

6-6

6-7

6-7

6-8 


\section{EXECUTIVE SUMMARY}

This document reports the activity of DOE/NASA Contract DEN3-289 for the first portion of the effort carried out in time period September 1982 through November 1983. The purpose of this 57 -month contract is to develop phosphoric acid fuel cell component technology for on-site power plant use. All evaluation is done at atmospheric pressure using hardware consistent with a 200-kW size power plant. This effort is being conducted in parallel with a Gas Research Institute (GRI) On-Site Fuel Cell Power Plant Technology Development Program, GRI Contract 5080-344-0405, and with a field test of a number of $40-\mathrm{kW}$ power plants under Contract 5080-3440308 .

In this first phase of the program, efforts were concentrated on subscale component technology development and screening, with the goal of selecting candidates for scale-up and long-term endurance testing. The next phase of the program (1984-1985) will be devoted to component development and scale-up evaluation. In the final phase, full-scale component evaluation and interaction technology will be the major activity.

In the period covered by this report, major development activity occurred in stack, inverter, reformer, and ancillary equipment technologies. In addition, an analysis of early $40-\mathrm{kW}$ field test power plant data was conducted to determine if this technology development program should respond to any field test problems.

A cell stack was fabricated and is being tested over a 5000 hour period to evaluate several advanced cell and stack features. Advanced features in this stack include totally encapsulated serpentine coolers at 10 cells per cooler, electrodes containing an acid condensation zone and acid refill provisions, and dry mix type electrode processing. This stack has run 2700 hours with stable performance. An acid addition scheme will be evaluated at the end of the 5000 hour test period.

An inverter bridge electrical design was established that results in a calculated full load efficiency of $94.8 \%$. Asymmetrical silicon controlled rectifiers (ASCR's) 
W'ere selected for use in the brassboard inverter, however, several gate turnoff (GTO) devices were selected for laboratory evaluation. Subcontracts were placed to fabricate the brassboard bridges, series reactors, and bridge control units. Evaluation of this equipment is planned in the 1984 effort of this contract. An output transformer with $99 \%$ full load efficiency was ordered and will be evaluated in the 1984 effort as part of the brassboard inverter test program.

A test program was conducted to evaluate two direct cooling approaches and one heat exchanger approach in an effort to obtain a low cost acid removal device. The spray cooling and contact saturator approaches were found to be slightly less expensive (on a $\$ / k W$ basis) than the baseline $40-\mathrm{kW}$ field test heat exchanger, but added significant complexity to the system. The preferred approach is a modified Teflon ${ }^{3}$ covered commercial heat exchanger. This commercial unit is simpler and is one-fifth the cost per kilowatt of the bare metal heat exchanger used in the 40-kW power plant.

Reformer catalysts were screened in order to obtain a candidate with lower pressure drop and performance equivalent to that of the $40-\mathrm{kW}$ field test catalyst. Several catalysts were found to have acceptable performance, with 10 to $40 \%$ of the pressure drop of the $40-\mathrm{kW}$ catalyst. Alternative shift converter catalysts were evaluated, and one candidate was selected for further evaluation. Testing of a hydrodesulfurization catalyst that does not require a costly presulfide treatment was initiated during this test period. An endurance test rig was prepared for evaluation of a process train with candidate catalysts from the above screening program: This train consists of beds containing the hydrodesulfurizer, reformer, and shift catalyst candidates, and also contains the necessary heat exchangers and controls to operate the catalyst beds at design conditions. The endurance test is planned for the 1984 effort. A six to seven tube reformer configuration was selected for the development reformer, and an industrial burner was evaluated for incorporation into the design. This evaluation included water table testing to establish the burner arrangement. Also, an infrared pyrometer was purchased for evaluation as an improved temperature control approach. 
Operational data from several early $40-\mathrm{kW}$ power plants were reviewed to determine the need for technology development interaction with the field test efforts. The purpose of the effort was to assure that the necessary adjustments were made to the Technology Development Program to address chronic failure modes. The Technology Development Program was adjusted to expand the effort in the cooling system, inverter logic card processing, and system reliability tasks. 


\section{INTRODUCTION}

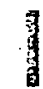

3

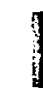

1

竞

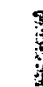

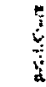

.

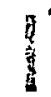

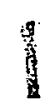

3

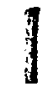

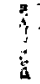




\section{ISTRODLCTION}

This report covers the work plan period September 1, 1982 through November 30, 1983 of the On-Site Technology Development Program (DEN3-289). The effort during this work period was divided into the following tasks:

Cel1 Technology (Task 1) - Evaluate fuel cell electrodes at on-site conditions in bench scale cells.

Cell Stack Development (Task 2) - Develop and evaluate electrode substrates, cell coolers, and acid replenishment techniques to improve performance and reliability and reduce costs of these components.

Power Processor Development (Task 3) - Develop inverter components and circuitry and fabricate a brassboard model for subsequent evaluation.

Heat Exchanger Development (Task 4) - Develop and evaluate alternative approaches to the condensate preheater/acid condenser heat exchanger.

Fuel Processor Development (Task 5) - Screen and select fuel processor catalyst for subsequent evaluation in a development reformer and a subscale fuel processing train.

Preprototype Power Plant Data Review (Task 6) - Assess data from verification and early field test power plants (DE-ACO1-80ET-17109) to identify any additional technology development program activities.

A parallel Gas Research Institute (GRI) On-Site Technology Development Program (Contract No. 5080-344-0405) with complementary tasks was conducted in 1983. The GRI effort will be reported separately. 
TASK 1 - CELL TECHNOLOGY

Subtask 1.1 Electrode-Catalyst Evaluation

\section{Objective}

The objective of this task is to demonstrate that cell performance and endurance goals can be met. These goals are defined in terms of a projected cell performance, referred to as E $+20 \mathrm{mV}$, and a projected decay of $63 \mathrm{mV}$ at 200 ASF in 40,000 hours, referred to as E-line decay. The goal performance is equivalent to $682 \mathrm{mV} / \mathrm{cell}$ at 200 amps per square foot at time zero. An additional objective is to determine the cell's ability to tolerate stressful operating conditions and hence to define an acceptable operating envelope consistent with the decay goal.

\section{$\underline{\text { Summary }}$}

Nine subscale cells with three different cathode catalysts on three different supports were evaluated under on-site conditions to select the best cathode catalyst/support combination for further testing. These cells are referred to as Series I cells in the discussion. This test series was initiated in the GRI on-Site Technology Development Program, as discussed in FCR-4991A. The GSB-18 cathode, modified to increase its hydrophobicity, was determined the best candidate.

Four subscale cells with different versions of the GSB-18 cathode were next run for 3000 hours under on-site conditions. Cells from these tests are referred to as Series II cells in this discussion. The two cells that showed the greatest stability were subjected to further tests to determine their tolerance to electrolyte volume swings and to shutdowns. After 8000 hours of operation one cell remains, running at $0.625 \mathrm{~V}, 200 \mathrm{ASF}, 400 \%, 80 \%: 50 \%$ fuel:air utilization, and 29 $\mathrm{mV}$ below the program goal performance. Three cells containing GSB-18 cathodes representative of those in the 30 -cell stack are also being tested to provide a subscale versus full-scale performance comparison. 


\section{Highlights}

- The HYCAN anode, manufactured by production methods, has shown excellent performance and stability in all of the subscale cell tests.

- Two cells with laboratory-made GSB-18 cathodes were within $7 \mathrm{mV}$ of the on-site performance goal of $E+20 \mathrm{mV}$ after 2000 hours of operation. Subsequent losses in performance occurred following diagnostic test procedures.

- The better of the above cells is $29 \mathrm{mV}$ below the on-site goal after 8000 hours of operation, during which time it has been subjected to three electrolyte dilution cycles and eighteen shutdowns.

- Further development is required to meet performance goals over long operating periods.

- Catalyst scaleup work is required to match the performance level of the production catalysts/electrodes to that of the laboratory version.

\section{Discussion}

Series I Cells

Nine subscale cells were started under' the GRI Technology Development Program to compare the performances of three different cathode catalysts on three different supports. The purpose of this test was to select the best cathode catalyst/support combination for the on-site power plant. The supports were designated GSA, GSB, and GSC. Tests in the laboratory conducted in an earlier UTC-funded program showed that the GSB and GSC supports are more resistant to oxidstion than GSA at high cathode potentials. This statement is based on direct measurements of the corrosion currents obtained from different support materials. The catalysts were 
platinum and two alloys of platinum. The alloys are proprietary UTC electrocatalysts identified by the numbers " $6 "$ and " 18 ".

The supported catalysts were fabricated into electrodes on porous, ribbed, carbon substrates. The platinum loading was $0.5 \mathrm{mg} / \mathrm{cm}^{2}$ of electrode. Portions of these laboratory-made electrodes, having an active area of 2 inches by 2 inches, were paired with HYCAN anodes prepared in the electrode production shop.

The HYCAN anode used in all of the tests is a UTC-developed electrode that has been adopted for general use. The platinum loading on the HYCAN anodes was $0.25 \mathrm{mg} / \mathrm{cm}^{2}$. The electrode pairs were built into subscale phosphoric acid fuel cells with silicon carbide matrices. Figure 1-1 shows the components of a typical subscale cell excluding the gaskets and seals. Figure 1-2 is a photograph of the test stand in which the cells were run.

The cells were operated at the following conditions:

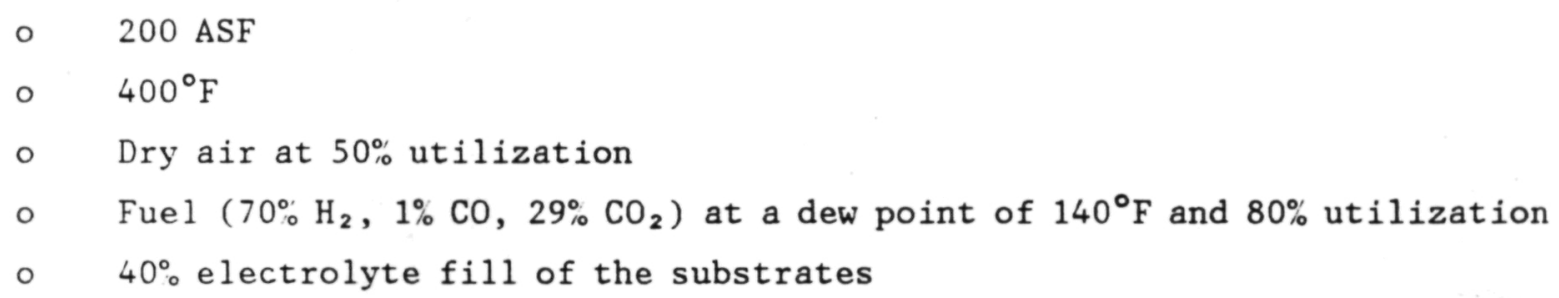

Diagnostic tests were run on the cells when they attained their maximum performances (at approximately 200 hours) and after each 1000 hours of load time.

In September 1982 the five cells with alloy cathode catalysts that were still on test and had accumulated 1600 hours on load under the GRI effort were transferred to this program. Figures 1-3, 1-4, and 1-5 are voltage versus time plots showing the entire performance histories of the nine original cells, including the period prior to the change of sponsorship. The solid line indicates the performance/ endurance goal for the program. Results and conclusions from the Series I tests are summarized in the following sections. 
ORIGINAL PAGE IS OF POOR QUALTTY

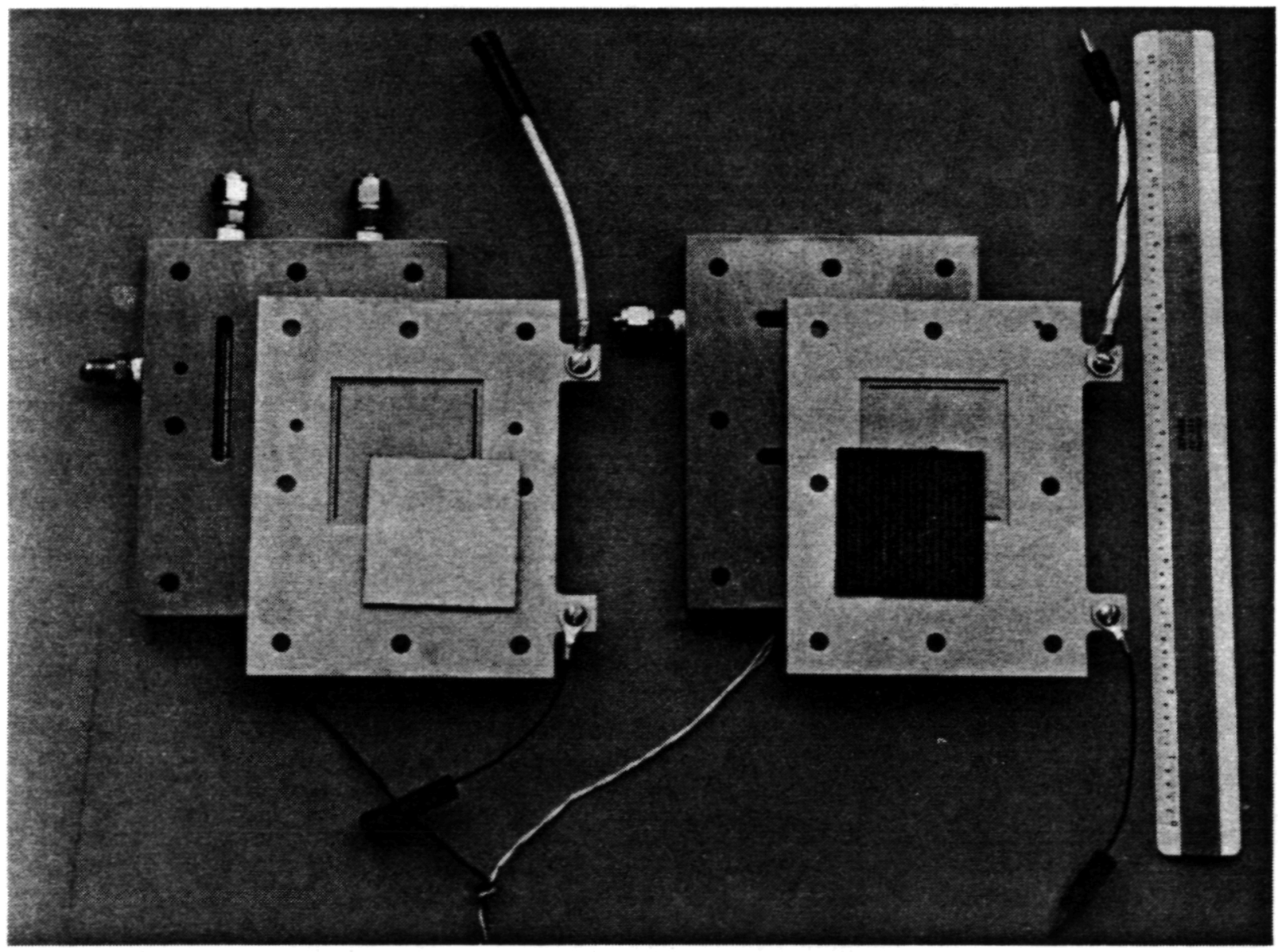

WCN-6515

Figure 1-1. Components of a Subscale Cell Excluding Gaskets and Seals 


\section{ORIGINAL PAGE IS
OF POOR QUALITY}

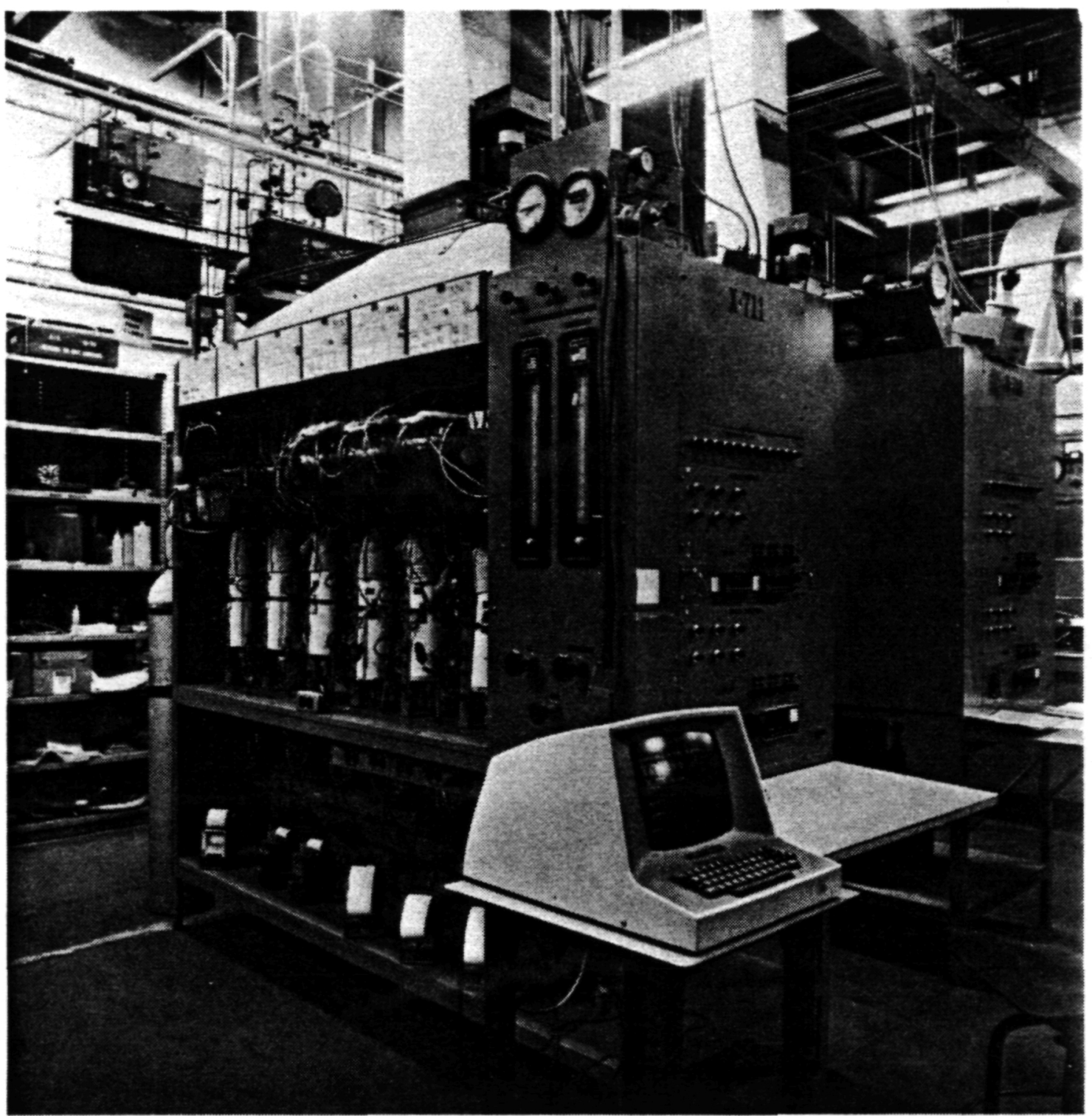

Figure 1-2. View of Stand Used to Test Subscale Cells 


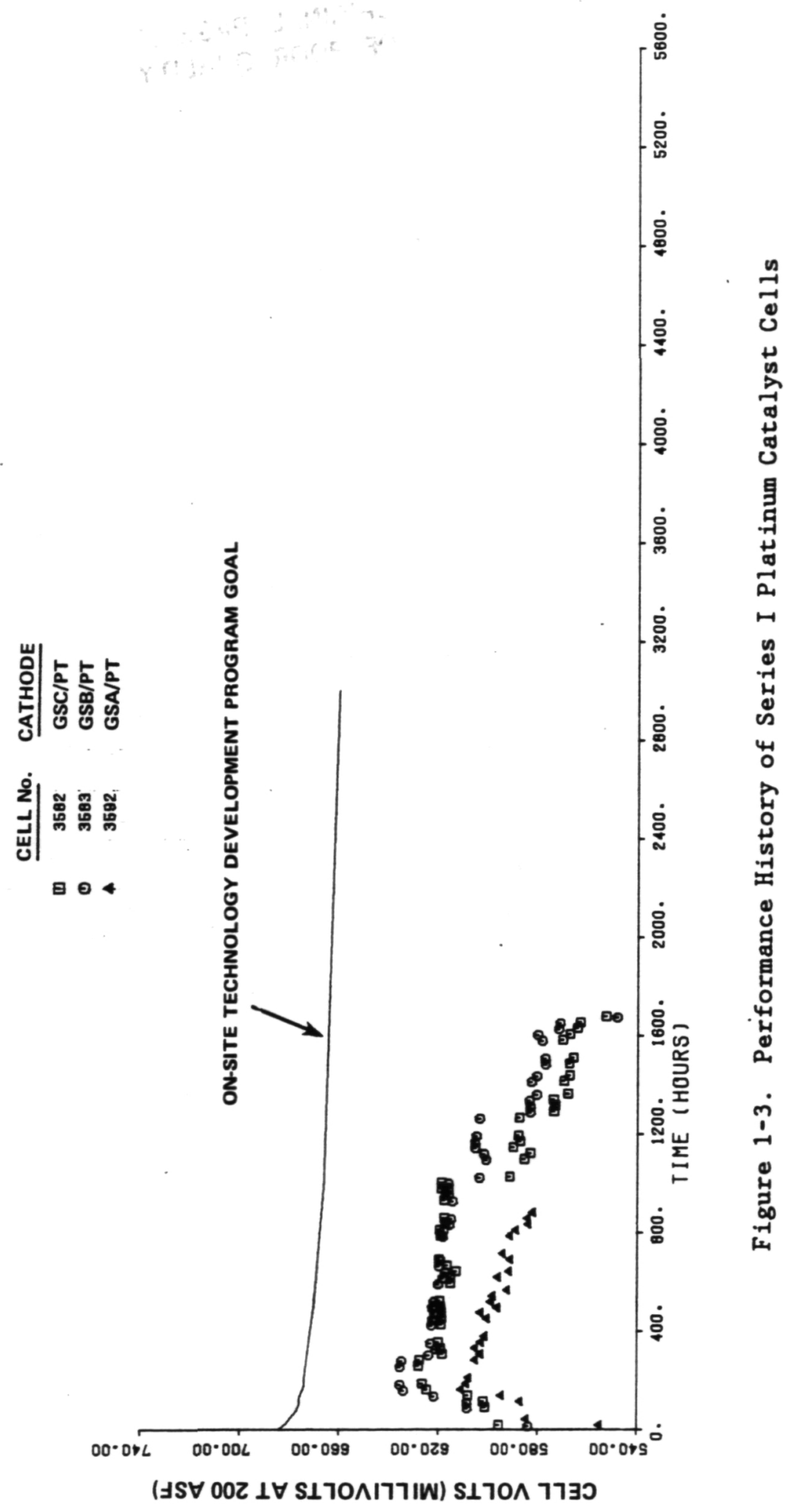



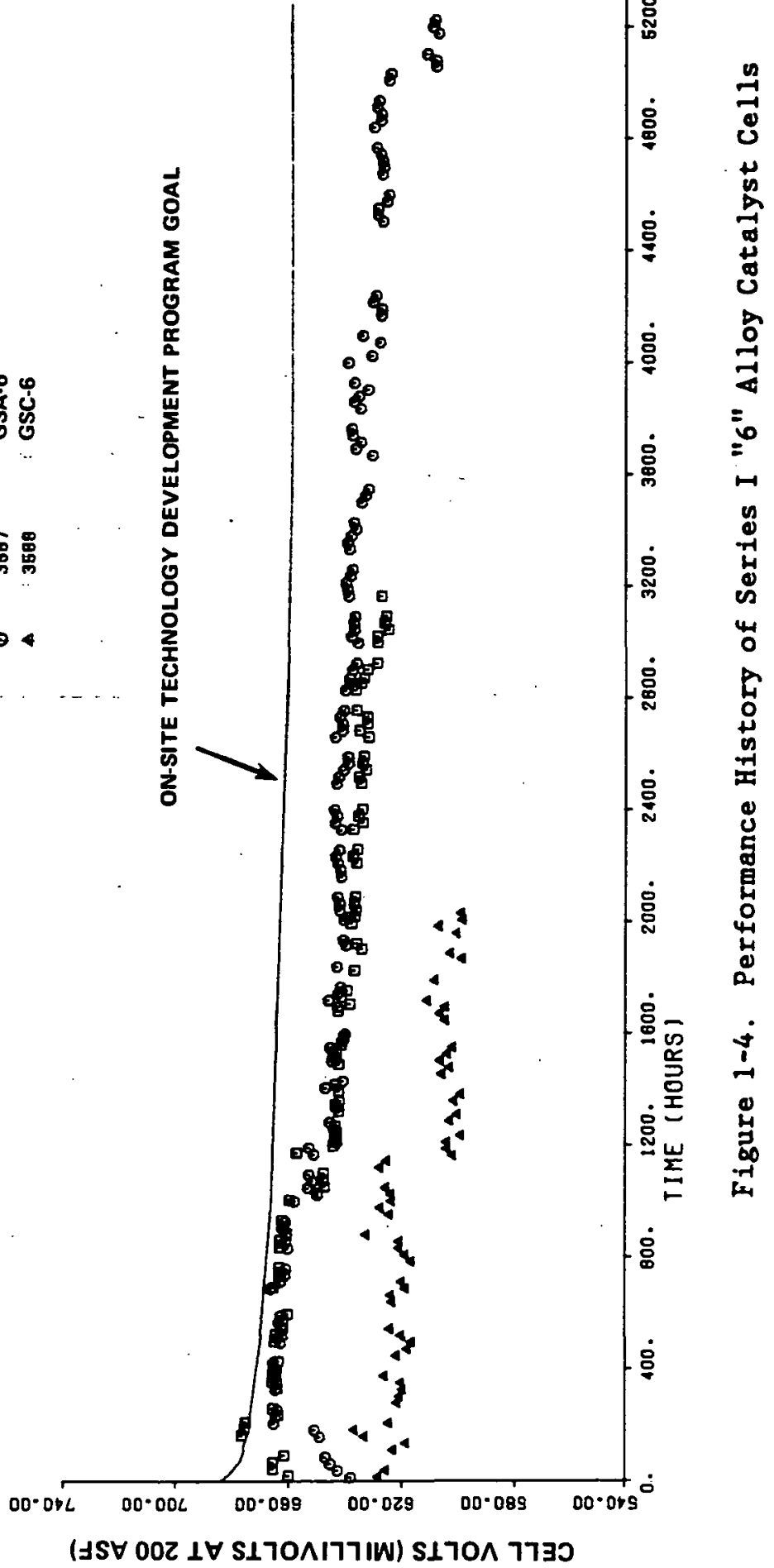


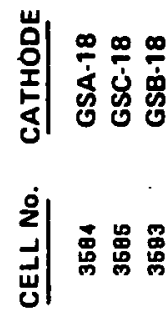

घe

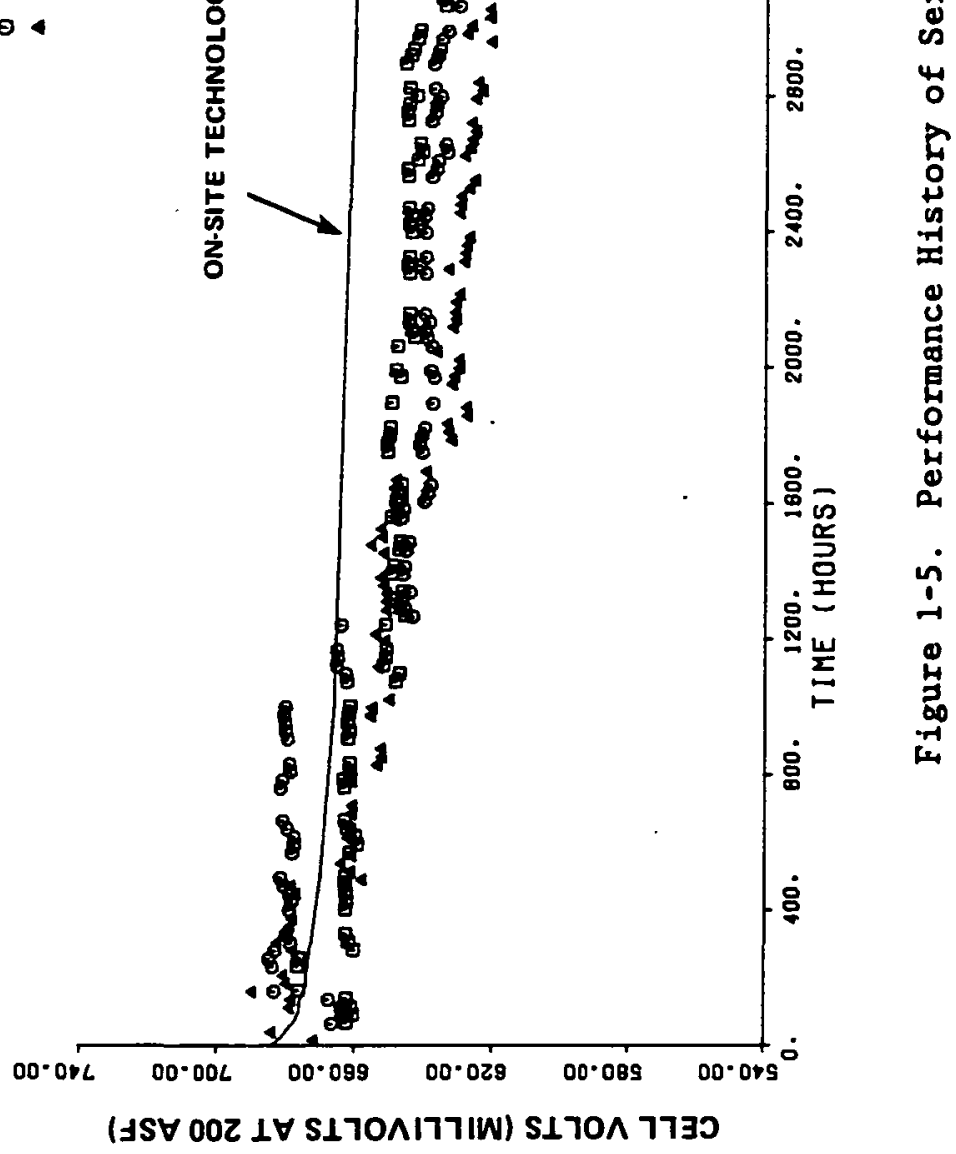


Anodes - Hydrogen gain is the principal diagnostic used to measure the performance and endurance of an anode. It is the increase in cell voltage that occurs when pure hydrogen is substituted for the normal fuel mixture, all other conditions being held constant.

The HYCAN anodes in the Series I tests performed very we11. With the exception of Cel1 3588 (GSC-6 cathode), the hydrogen gains were all within the range of $21 \pm 3 \mathrm{mV}$ at $200 \mathrm{ASF}$ and remained constant throughout the test program. The hydrogen gain for Cell 3588 was $35 \mathrm{mV}$, which is atypical for this type of anode. It is concluded that the HYCAN anode can meet the performance and stability requirements of the On-Site Program.

Matrix - The internal resistance of all the cells was $22 \pm 2 \mathrm{mV}$ at 200 ASF, and remained constant throughout the test. At no time were there any signs of shorting or crossover. It is concluded that the silicon carbide matrix has the requisite integrity and stability for use in the on-site power plant.

Cathodes - The invariance of the anodes and of the cell internal resistance leads to the conclusion that the differences in cell performance levels and decay characteristics (shown in Figures 1-3, 1-4, and 1-5) reflect differences in the cathodes. Oxygen gain, as discussed below, is the increase in voltage of a cell when oxygen is substituted for air on the cathode and all other conditions are held constant.

(a) GS/Pt Cathodes: The cells with unalloyed, supported platinum as their cathode catalyst performed poorly and decayed rapidly (Figure 1-3). All three GS/Pt cells had large oxygen gains $(\sim 110 \mathrm{mV}$ at $200 \mathrm{ASF})$ at the beginning of the test, and three increased to $\sim 155 \mathrm{mV}$ at $200 \mathrm{ASF}$ by the time the tests were concluded. The desired value for this parameter is $80 \mathrm{mV}$ at $200 \mathrm{ASF}$. 
(b) Alloy Cathodes - Performance: The cathodes with the "6" and "18" platinum alloys as electrocatalysts also had increased oxygen gains with time. Not only were the oxygen gains high initially, but they also increased appreciably at around 1000 hours following diagnostic tests. This caused a sharp drop in cell performance in the 1000-1200 hour time period (Figures 1-4 and 1-5).

Peak performance data taken early in life are given in Table 1-1. The data show that the "18" alloy is more active initially than the " 6 " alloy.

TABLE 1-1. SERIES I CELLS - PEAK PERFORMANCE DATA

\begin{tabular}{|c|c|c|c|}
\hline Cel1 非 & Cathode & $\begin{array}{l}\text { Peak Pe } \\
\text { (iR-fre }\end{array}$ & $\begin{array}{l}\mathrm{H}_{2} / \mathrm{O}_{2} \\
0 \mathrm{ASF})\end{array}$ \\
\hline $\begin{array}{l}3592 \\
3583 \\
3582\end{array}$ & $\begin{array}{l}\mathrm{GSA} / \mathrm{Pt} \\
\mathrm{GSB} / \mathrm{Pt} \\
\mathrm{GSC} / \mathrm{Pt}\end{array}$ & $\begin{array}{l}0.775 \\
0.777 \\
0.775\end{array}$ & $\begin{array}{c}\text { Average } \\
0.776\end{array}$ \\
\hline $\begin{array}{l}3587 \\
3586 \\
3588\end{array}$ & $\begin{array}{l}\text { GSA - } 6 \\
\text { GSB }-6 \\
\text { GSC - } 6\end{array}$ & $\begin{array}{l}0.795 \\
0.802 \\
0.791\end{array}$ & $\begin{array}{c}\text { Average } \\
0.796\end{array}$ \\
\hline $\begin{array}{l}3584 \\
3593 \\
3585\end{array}$ & $\begin{array}{l}\text { GSA - } 18 \\
\text { GSB }-18 \\
\text { GSC }-18\end{array}$ & $\begin{array}{l}0.803 \\
0.808 \\
0.809\end{array}$ & $\begin{array}{c}\text { Average } \\
0.807 \\
.\end{array}$ \\
\hline
\end{tabular}

(c) Alloy Cathodes - Decay: Some of the cells were run for extended periods to obtain data regarding electrode stability. Data from diagnostic tests at 3000,4000 , and 5000 hours are shown in Table 1-2. At these times the oxygen gains of all the cathodes were in excess of $100 \mathrm{mV}$. 
TABLE 1-2. SERIES I CELIS - $\mathrm{H}_{2} / \mathrm{O}_{2}$ PERFORMANCE WITH TIME

\begin{tabular}{|c|c|c|c|c|}
\hline \multirow[b]{2}{*}{ Ce11 非 } & \multirow[b]{2}{*}{ Cathode } & \multicolumn{3}{|c|}{ Performance on $\mathrm{H}_{2} / \mathrm{O}_{2}$} \\
\hline & & $\begin{array}{l}\text { (iR-fre } \\
3000 \mathrm{Hr} .\end{array}$ & $\begin{array}{r}\text { volts at } \\
4000 \mathrm{Hr}\end{array}$ & $\begin{array}{l}00 \text { ASF) } \\
5000 \mathrm{Hr}\end{array}$ \\
\hline 3587 & GSA -6 & 0.775 & 0.779 & 0.773 \\
\hline 3586 & GSB -6 & 0.772 & - & - \\
\hline 3584 & GSA-18 & 0.780 & 0.777 & 0.775 \\
\hline 3593 & $G S B-18$ & 0.776 & 0.780 & - \\
\hline 3585 & GSC-18 & 0.784 & - & - \\
\hline
\end{tabular}

\section{Conclusions}

- The on-site performance goal can be met, at least initially, with cells containing the "18" alloy as cathode catalyst.

- GSB is the preferred support for the cathode catalyst because of its high resistance to oxidation.

- The Series I cathodes were inadequately wet-proofed, as indicated by the rapidly decaying cell performance and associated increases in oxygen gain.

Series II Cèlls.

The Series II cells all contained HYCAN anodes paired with GSB-18 cathodes (Table $1-3)$. 
TABLE 1-3. IDENTIFICATION OF SERIES II CELLS

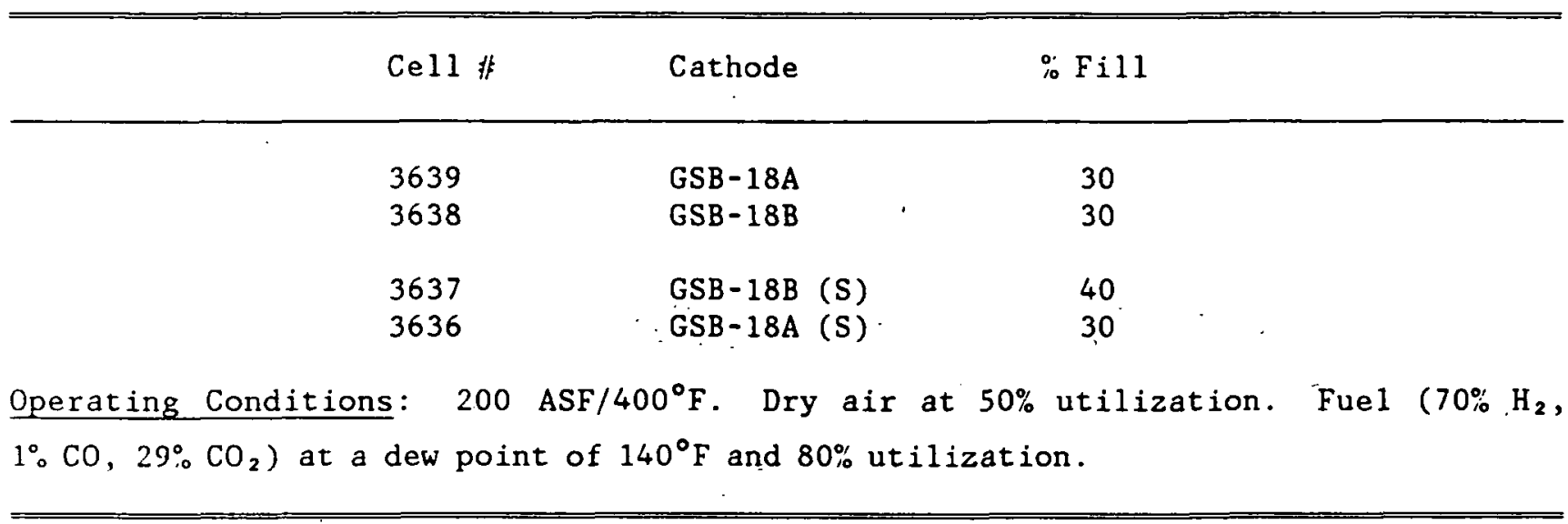

These cathodes were all more hydrophobic than those in the Series I cells, the 18B cathodes being the most hydrophobic. In two of the Series II cells (indicated by "S"), the cathode catalyst layers were structurally modified to improve the transfer of electrolyte across the cell.

The performance histories of the cells out to 3000 hours are shown in Figure 1-6. The cells did not attain their maximum voltages until 200-600 hours into the test. only one cell attained the performance goal, and then only for a brief period. By 3000 hours, differences in performance had disappeared, and all four cells were clustered around E-1ine. Diagnostic tests showed that the oxygen gains for Series II cells were appreciably lower than for Series I cells $(\sim 85 \mathrm{mV}$ at 200 ASF, as compared to $120 \mathrm{mV}$ at $200 \mathrm{ASF}$ for Series I cathodes), confirming that the tendency of the catalyst layers to flood was greatly reduced.

Following the diagnostic tests, at 3000 hours the two cells containing cathodes of the " $S$ " variety (builds 3636 and 3637) showed unacceptably large losses in performance accompanied by erratic behavior, and were terminated. It was concluded that the modification made to improve electrolyte transfer through the cathode catalyst layer caused other electrolyte management problems.

The two remaining cells (builds 3638 and 3639 ) were then subjected to the stress tests of electrolyte dilution and shutdowns. 
ORIGINAR PAGE IS

OF POOR QUALTTY

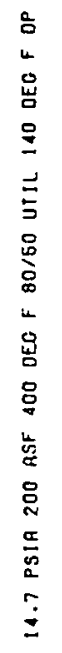

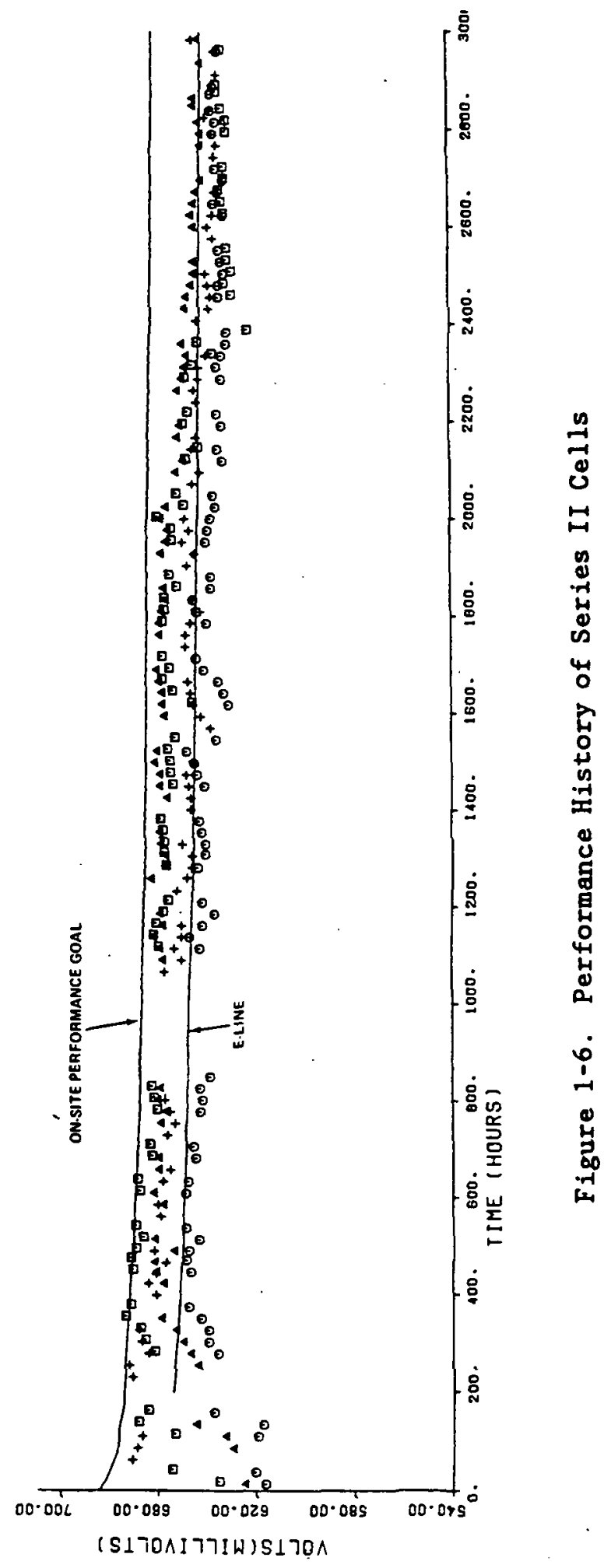


Electrolyte Dilution Tests - Electrolyte dilution of cells 3638 and 3639 was established by lowering the cells' temperatures to $156^{\circ} \mathrm{F}$ while maintaining the dew point of the fuel. In this way, the electrolyte in the cells became diluted (from $99 \%$ to $50 \% \mathrm{H}_{3} \mathrm{PO}_{4}$ ), and its volume expanded to fill $80 \%$ of the available capacity of the substrates. The electrolyte dilution cycle (i.e., wet-up followed by dry-out) was run three times on each cell. Cell 3638 with the GSB-18B cathode showed a small loss in performance, whereas Cell 3639 with the GSB-18A catalyst layer showed a substantial loss (Figure 1-7).

Tolerance to Shutdown/Restart - Following the completion of the electrolyte dilution tests, the two remaining Series II cells with GSB-18 cathodes and HYCAN anodes were subjected to shutdown trials. In the period from 4885 hours to 5794 hours Cell 3638 was subjected to a series of 11 three-day shutdowns to room temperature. The cell was removed from load and a semiconducting diode was placed across it to keep cathode potential at around .5V. It was allowed to cool to room temperature (about one hour) on a trickle flow of dry $\mathrm{H}_{2}$ and stagnant air. At room temperature the cell was capped. There was no protection from solidification of electrolyte. The cell was restarted on the third day. Measurements of conductivity show that the electrolyte does not solidify in that time. This resulted in a net loss in performance of about $5 \mathrm{mV}$ at $200 \mathrm{ASF}$. Between 4860 hours and 5340 hours, Cell 3639 was shutdown six times and suffered a net loss of $18 \mathrm{mV}$. Cell 3639 was terminated. The catalyst layer in Cell 3638 is more hydrophobic than that in Cell 3639 .

The only surviving Series II cell (Build 3638) has now been on test for over 8000 hours (Figure 1-8) and has experienced a total of eighteen shutdowns. Its present performance is $0.629 \mathrm{~V} / 200 \mathrm{ASF}$-- $5 \mathrm{mV}$ below E-line -- and it will continue running at on-site conditions to 10,000 hours. 


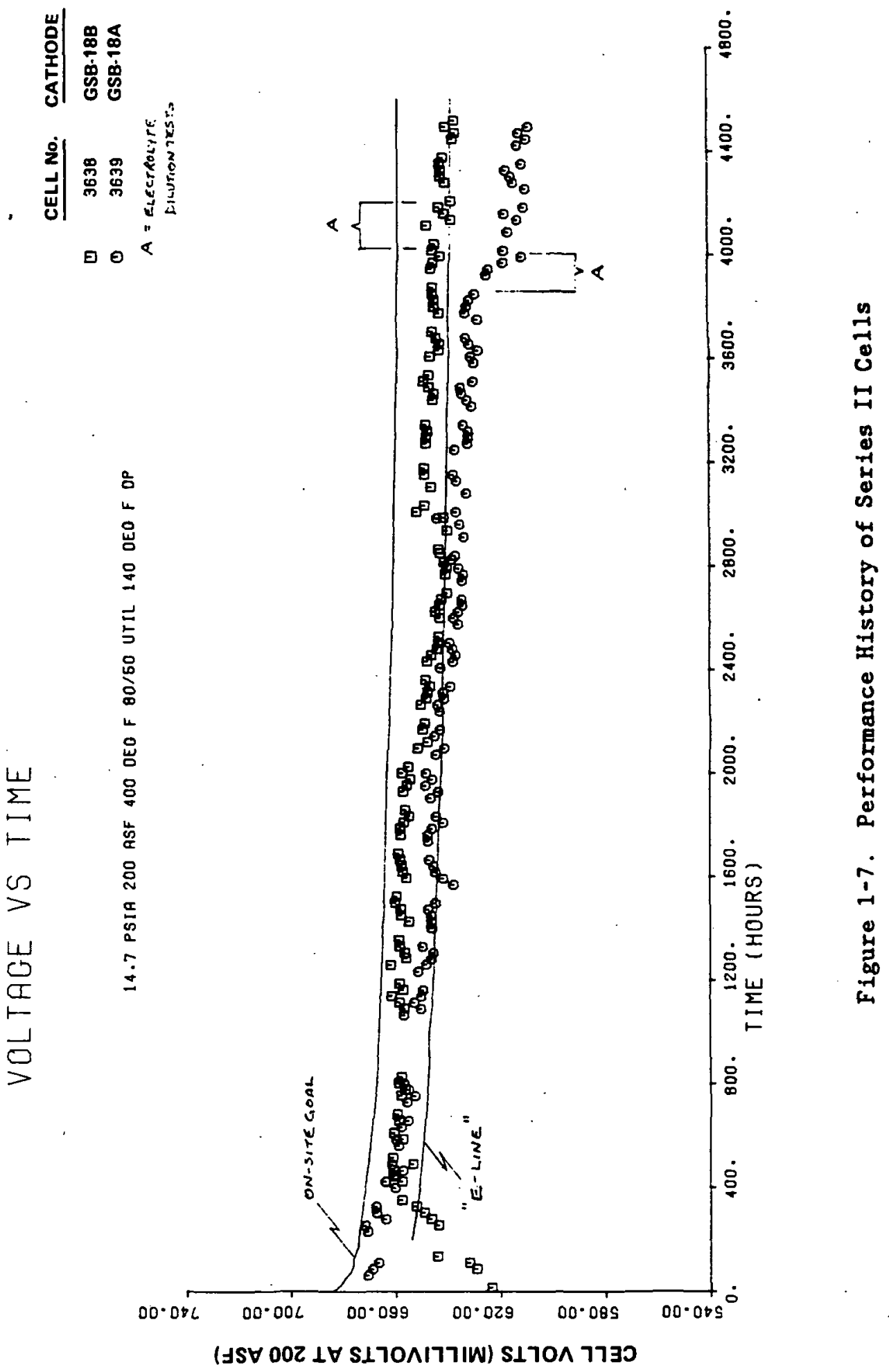




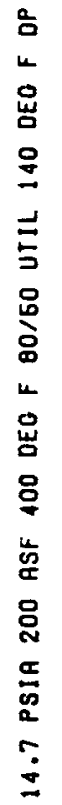

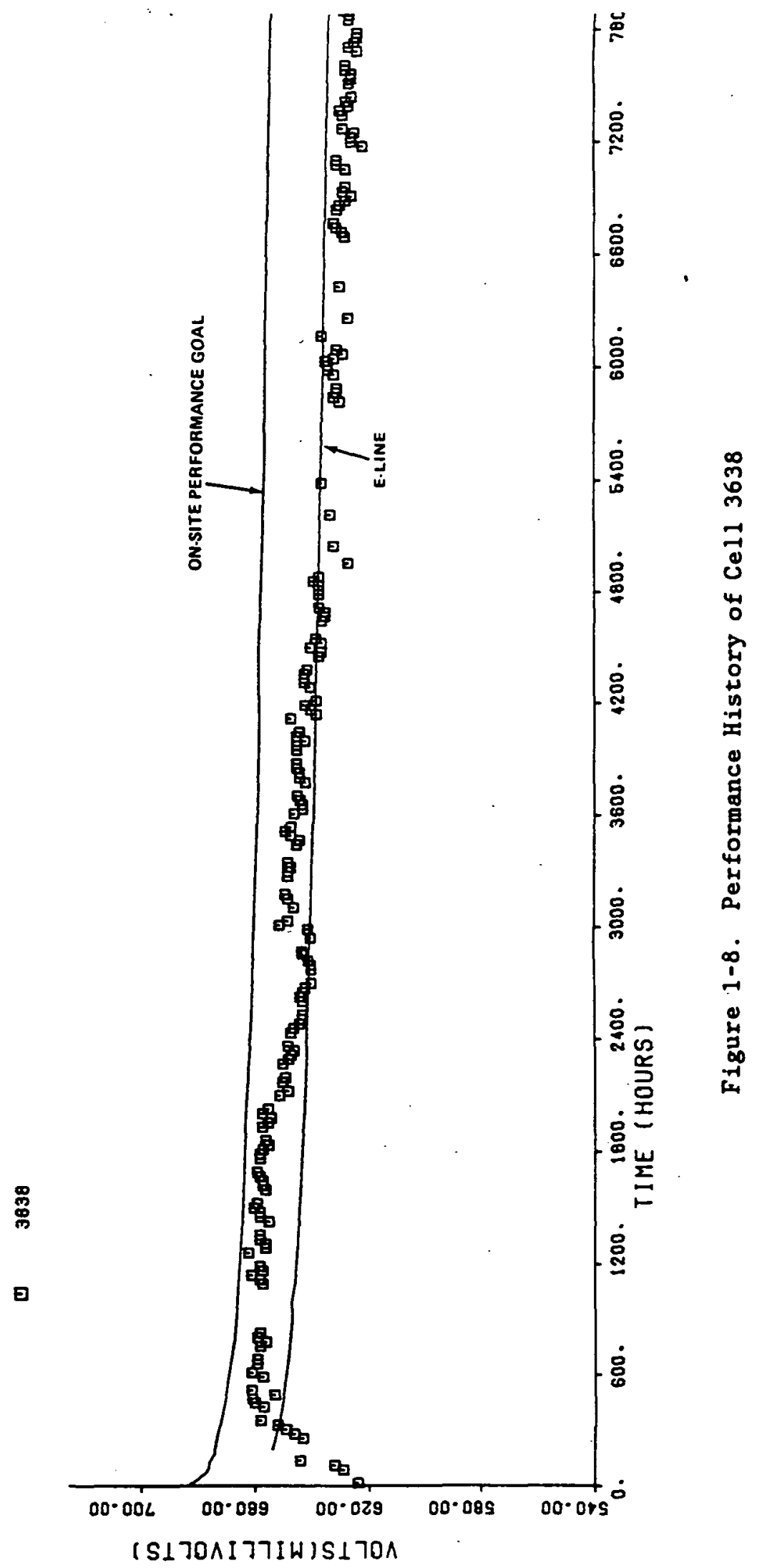




\section{Evaluation of Production Catalysts and Electrodes}

Catalysts and electrodes prepared in the laboratory that have shown acceptable performance and stability in subscale cell tests are subsequently evaluated in full size stacks. This involves increasing the catalyst batch sizes from grams to kilograms in order to provide sufficient catalyst for the larger electrodes. To evaluate the scaleup trials, sections cut from experimental fabrication runs of full size electrodes are tested in subscale cells. Electrodes that are finally selected for stack testing are also pre-tested in subscale cells to obtain a preview of their behavior and operating characteristics.

Subscale Tests of 30 -Cell Stack Electrodes - Both wet mix and dry mix procedures were used to make catalyst layers for the $3.2-\mathrm{ft}^{2}$ electrodes in the 30 -cell stack, as described in subtask 2.4. The dry mix electrode procedures were developed in the associated GRI On-Site Technology Development Program.

To obtain a preview of the stack performance, pieces cut from 3.2-ft ${ }^{2}$ electrodes were built into 2 -inch by 2 -inch cells. Descriptions of these cells and their short-term performance are given in Table 1-4.

TABLE 1-4. SUBSCALE CELL TESTS OF ELECTRODES OF THE TYPES USED IN THE 30-CELL STACK

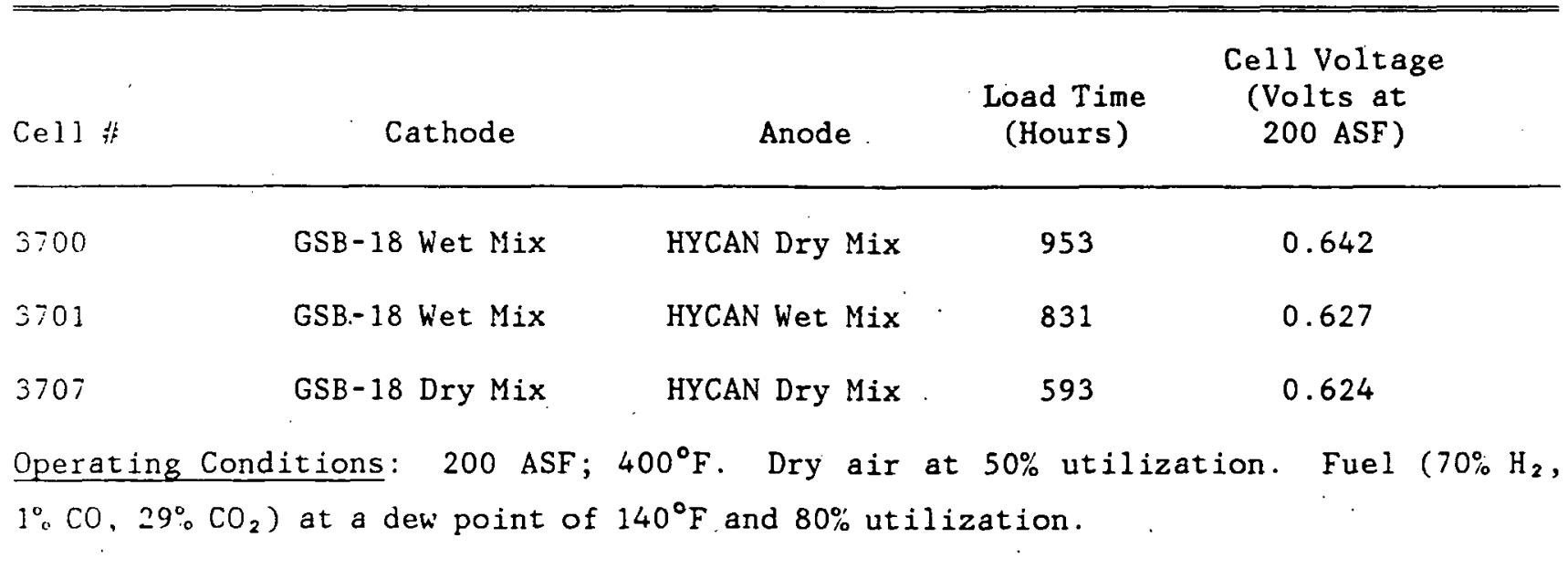


Performance levels of subscale cells containing stack electrodes are lower than the Series II cells, whose average performance was $0.650 \mathrm{~V}$ at $200 \mathrm{ASF}$ at the same load time.

Cel1 3707 was damaged due to a test stand malfunction, the other two cells have now run for over 4000 hours and their performance histories are shown in Figure 1-9. This figure also shows the average performance of cells in the 30-cell stack and confirms the usefulness of subscale cell tests in predicting the performance of full size components. Development work designed to raise the performance level of the production electrode is in progress under the GRI On-Site Technology Development Program.

\section{Evaluation of Production Electrodes}

Two subscale cells with shop-made GSB-18 cathodes (Builds 3739 and 3771 ) and two cells with shop-made GSB-26 cathodes (Builds 3751 and 3772) have been started recently to obtain long-term endurance data on scaled-up catalysts and electrodes. The GSB-26 is a derivative of the GSB-18 and, in laboratory versions, has shown improved performance when tested under the GRI On-Site Program. These tests will be continued through 1984. 


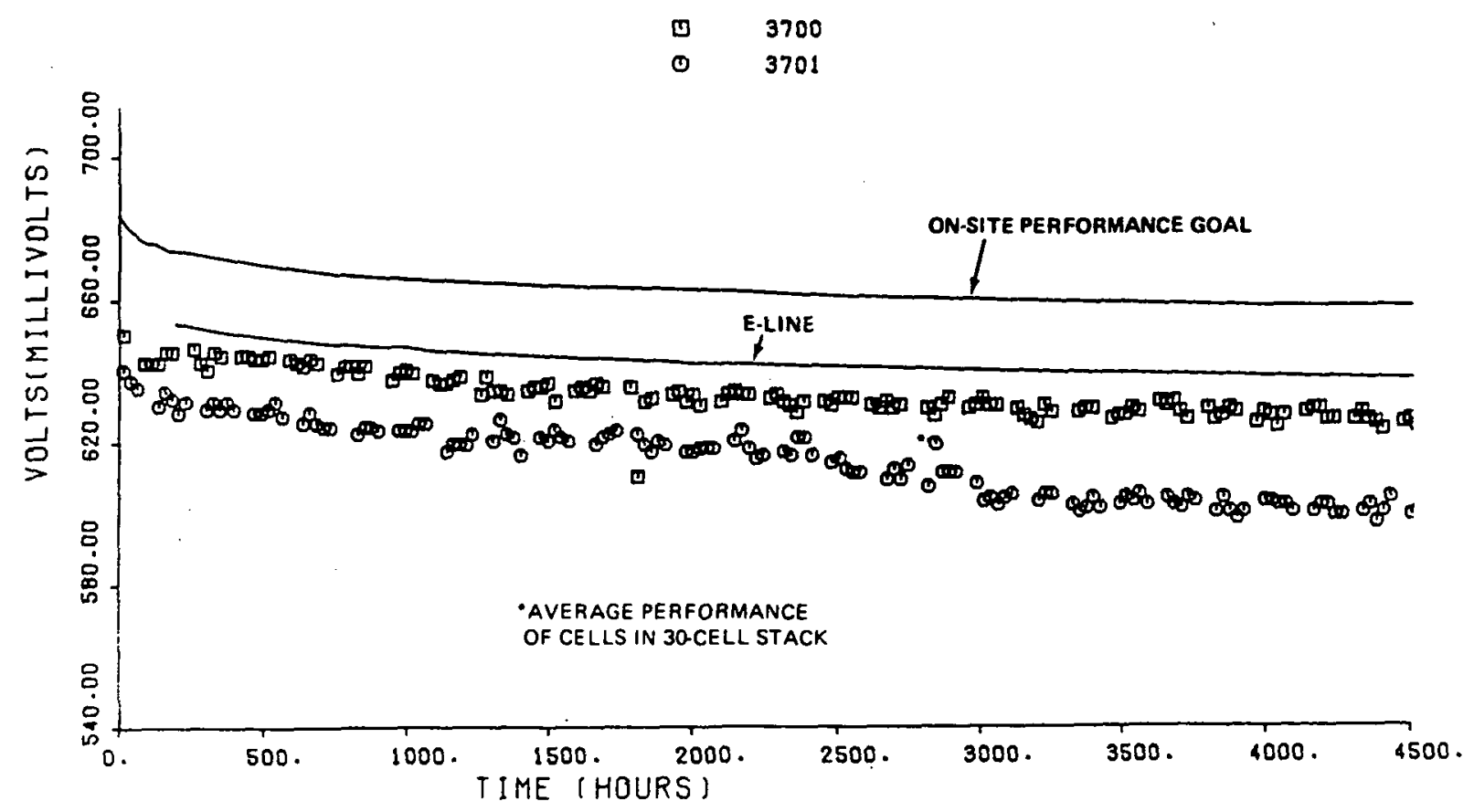

Figure 1-9. Stack Cell Performance Compared to Subscale Cell Performance 
TASK 2 - STACK DEVELOPNENT

\section{Subtask 2.1 - Electrode Substrate Technology}

\section{Objectives}

The objectives of this subtask are to increase the acid storage capacity of the cell by approximately $50 \%$ without compromising performance or cost, and to develop lower cost substrate materials. To increase acid storage, a dual porosity substrate will be formed having finer pores in the rib than in the web, thereby providing the capacity for storing additional acid in the rib. To reduce costs, mass produced precursors are being heat treated to produce fuel cell substrates.

\section{Summary}

Dual porosity substrates were formed on the dual belt substrate machine, developed in the Electric Utility Technical Development Program (DEN3-191), by forming web and substrate layers in separate operations. The effective diffusion coefficient of the dual porosity substrates indicates a lower diffusional resistance than that of a conventional substrate with an equivalent electrolyte fill. Two-inch by two-inch cells containing dual porosity substrates were started at the end of the period and are being performance tested. Performance is good, and will ultimately be determined as a function of electrolyte fill and compared to that of a standard substrate.

The influence of fiber diameter on the substrate's pore spectra was determined through tests using combinations of two and three distinct fiber diameters. It was found that median pore size and the breadth of pore distribution are a function of weighted fiber diameter.

Scaleup of low cost substrates, demonstrated previously at the subscale level, was initiated. Vendors having the potential to produce the requisite precursors were identified. Two production runs of material were made. Parts from both runs were unacceptable after carbonization, due to delamination in one case and cracking in 
another. Minor changes in materials and processing are being made to overcome these problems.

\section{Highlights}

- Dual porosity substrates achieved performance equivalent to conventional substrates.

$\circ$

Dual porosity substrates have lower diffusional resistance than conventional ribbed substrates with an equivalent electrolyte fill.

- The pore spectra of a substrate can be broadened by using combinations of fibers with larger diameters. Median pore size increases as fiber diameter increases.

\section{Discussion}

Dual Porosity (Electrolyte Management) - Initial development of dual porosity substrates under GRI Contract 5080-344-0405 showed that the desired acid distribution could be obtained, but electrode performance was deficient. "Second generation" dual porosity handsheets, with the rib layer containing a combination of standard and short, or "whisker", fibers increased electrolyte storage by shifting the pore spectra between the rib and web components. Typical pore spectra are shown in Figure 2:1-1.

Two-inch by two-inch cells built from handsheet bilayers had marginal performance due to higher-than-normal diffusion losses. The cause of the high diffusion losses was not understood and pointed to the need for a more analytical technique to characterize substrate diffusion resistance. 

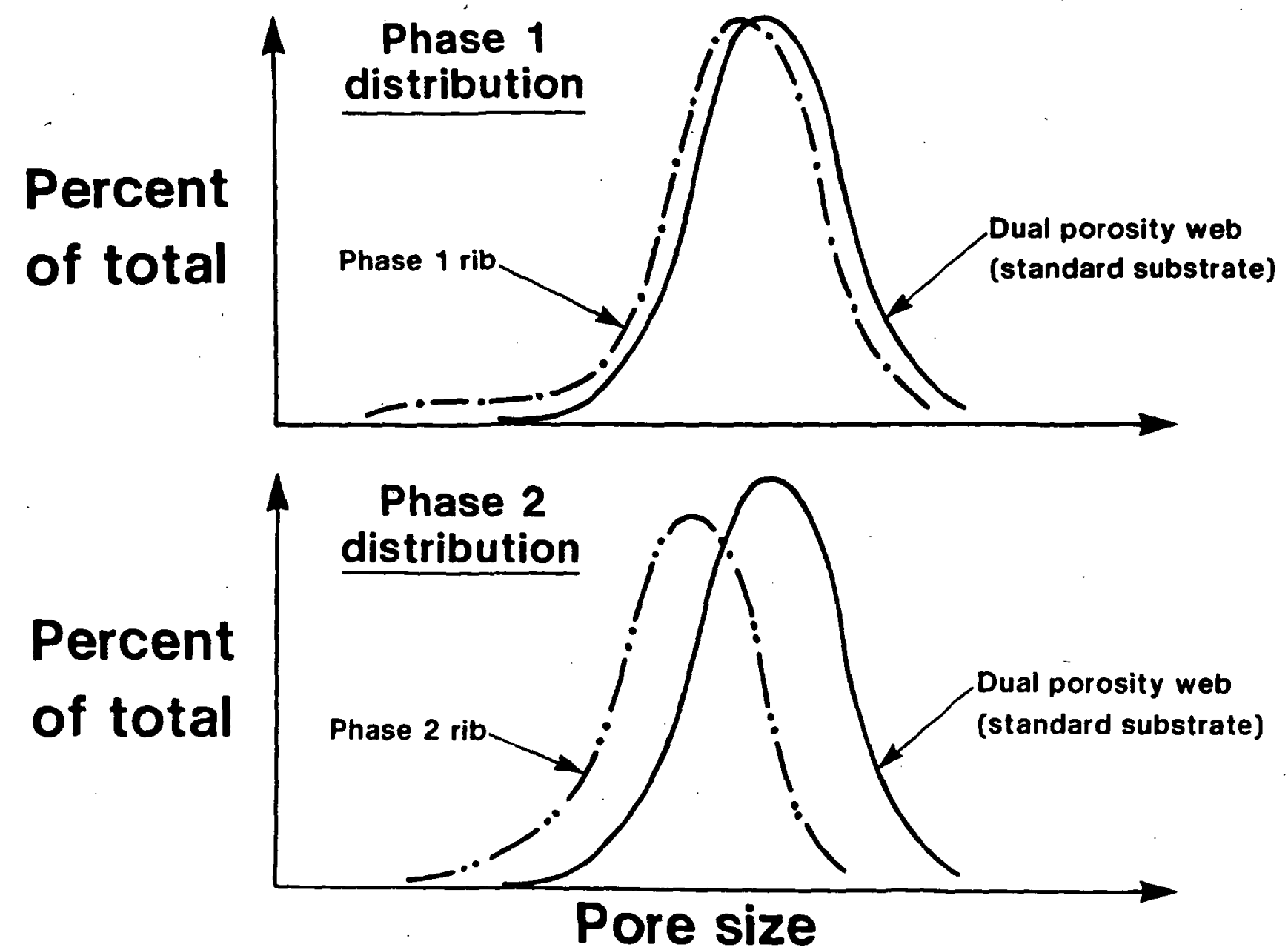

Figure 2.1-1. Pore Distribution of Dual Porosity Substrates 
An apparatus and measurement technique was developed to measure the effective diffusion coefficient of a substrate. A schematic of the apparatus is shown in Figure 2.1-2. Substrate samples 1-1/8 inches by 1-1/8 inches are mounted on Teflon gaskets with an open area of 7/8-inch by 7/8-inch. Three substrate samples are stacked one on top of the other, with rubber-type spacers between the Teflon gaskets to facilitate good sealing. $S F_{6}$ is used as the diffusing gas and $N_{2}$ as the purge gas. A pressure transducer that measures $1 / 10,000^{\prime \prime} \mathrm{H}_{2} \mathrm{O}$ is used to monitor $\Delta \mathrm{P}$ across the sample. The apparatus and technique have been used to measure the effective diffusion coefficient of flat electrode samples, conventional ribbed substrate samples, and dual porosity ribbed substrate samples. Figure 2.1-3 shows how ribbed, dual porosity samples compared with a conventional ribbed sample. It should be noted that the dual porosity samples have a somewhat higher diffusion coefficient at equivalent electrolyte fills. The dual porosity diffusion data is an average of the data obtained on first and second generation components. The dual porosity substrates that exhibited high diffusional losses were made as handsheets. The dual porosity substrates tested this year were made on the double belt substrate machine and did not have a diffusion problem. The difference in behavior between the two groups is attributed to differences in fabrication procedure.

The feasibility of manufacturing dual porosity substrates was investigated by forming full size dual porosity substrates on the double belt substrate machine. Standard length fibers were used to form a low density web $25-30$ mils thick. The desired rib density was achieved with both first generation and second generation handsheet approaches. The first generation approach used an alternate fiber $30 \%$ shorter than the standard fiber. The second generation approach uses a $50 / 50$ combination of regular standard fibers and standard fibers that were chopped to $1 / 10$ of their original length. The rib layer was deposited on the previously cured web layer, and the two layers were joined by hot compaction.

Seventy full size dual porosity substrates were formed, carbonized, and graphitized. Four typical full size parts were used for electrode processing. One anode and one cathode were made for both first and second generation dual porosity substrates. 


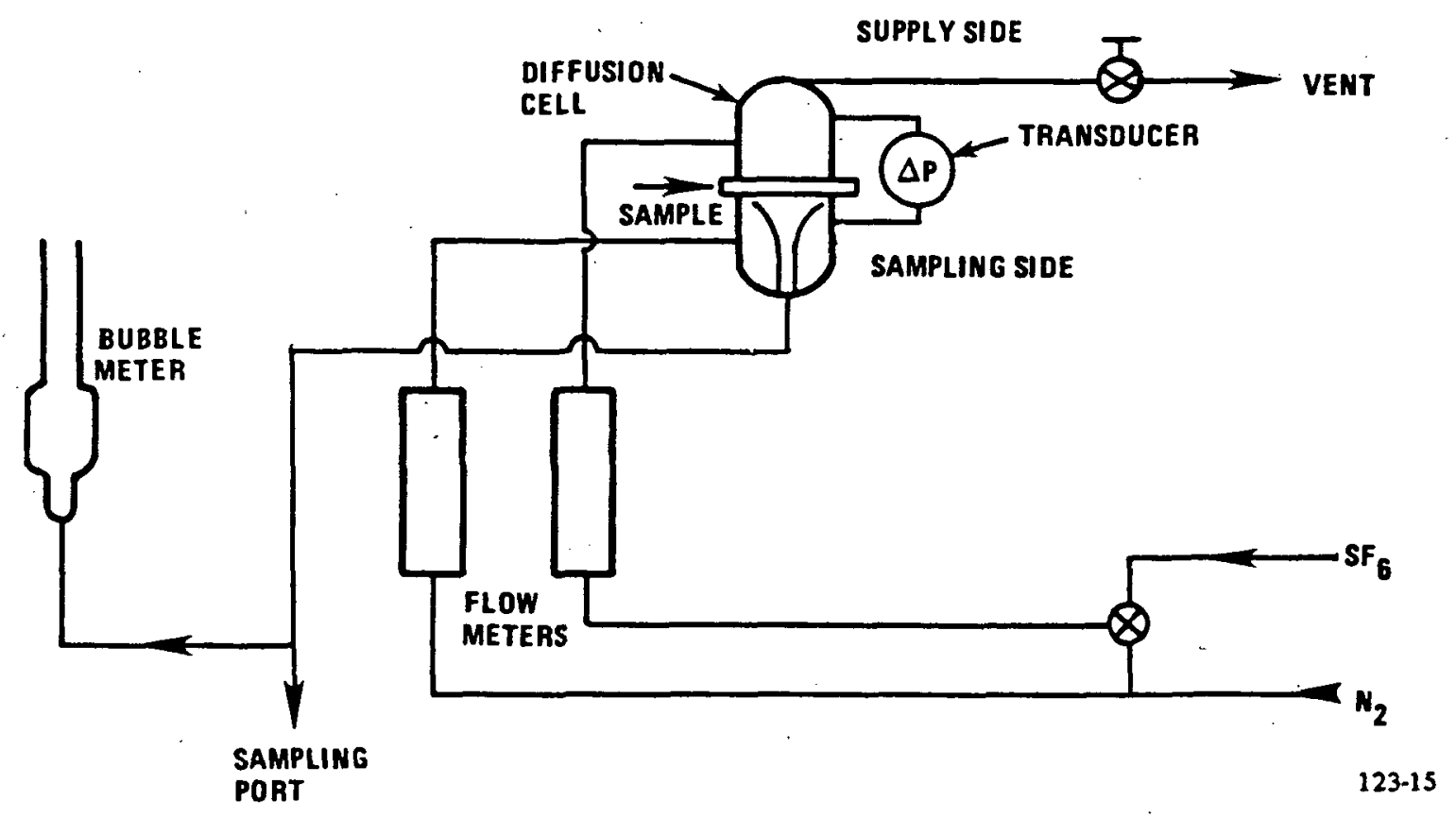

Figure 2.1-2 Schematic of Diffusion Apparatus 


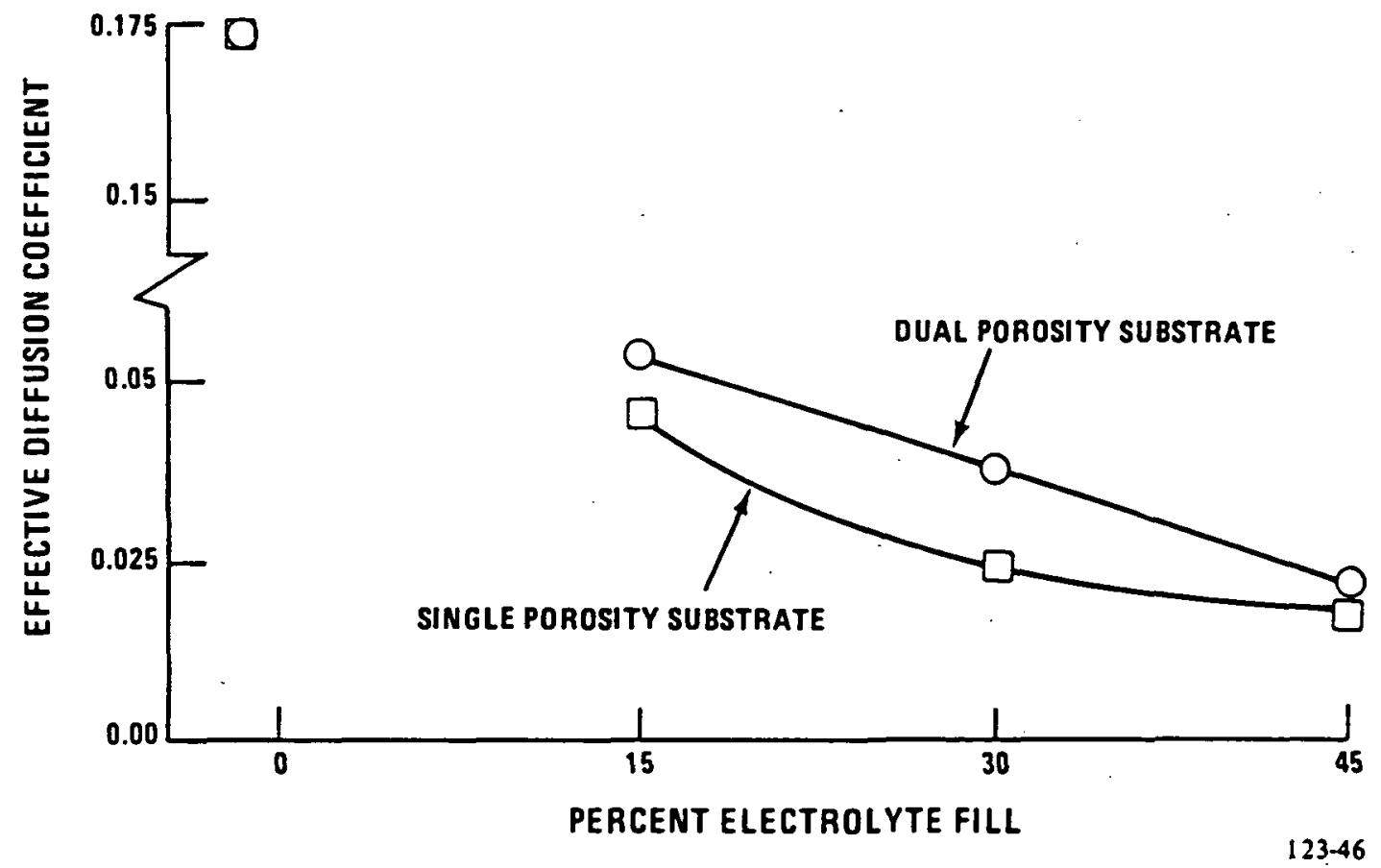

Figure 2.1-3 Effective Diffusion Coefficient vs. Percent Electrolyte Fill for Dual Porosity and Single Porosity Substrates 
Diffusion samples were formed from both types of dual porosity substrates also. Two-inch by two-inch cell performance and diffusion results are reported herein.

Subscale cells containing dual porosity substrates made on the dual belt substrate machine were started near the end of the reporting period. Initial performance of the cells is very good. The initial electrolyte fill is equal to $30 \%$ of the substrate void volume. Additional electrolyte fill will be added in increments and the performance as a function of percent fill will be compared to a conventional ribbed substrate.

\begin{tabular}{|c|c|c|c|c|}
\hline Build & Configuration & Time & Volts/200 ASF & E-Line \\
\hline 3762 & Control (single pore substrate) & 282 & 0.679 & .654 \\
\hline 3784 & 1st Generation (dual pore substrate) & 278 & 0.664 & .654 \\
\hline 3783 & 2nd Generation (dual pore substrate & 278 & 0.674 & .654 \\
\hline
\end{tabular}

Another approach to forming a dual porosity substrate is to vary the pore spectra of the substrate by varying fiber diameter and fiber length. The approach used in the first and. second generation handsheets was to vary density by varying fiber length. Experimental fibers comprised of three fiber diameters and three nominal lengths were obtained for use in evaluating the influence of fiber diameter and of fiber length. A test matrix with 28 elements was developed and subscale substrates were formed. The test matrix is summarized in Table 2.1-1.

The substrates include nine made from the basic fiber diameter with variable length, nine made from combinations of two different diameters holding length constant, and ten made from combinations of three diameters holding length constant. The subscale substrates were heat treated and samples submitted for porosimetry. 


\section{OF POOR QUALTTY}

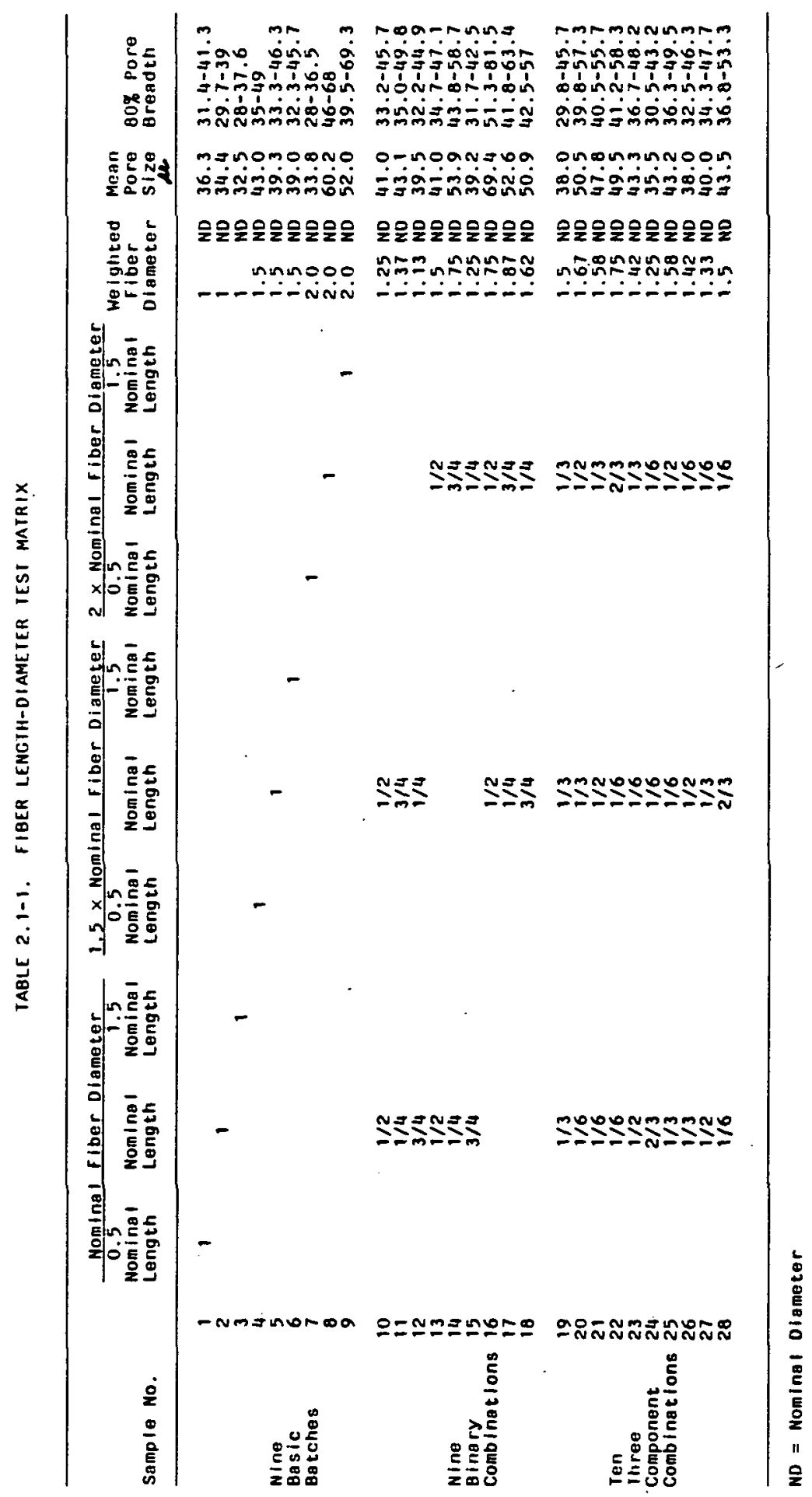


The results of the porosimetry are presented in Figures 2.1-4 and 2.1-5. In these figures pore size is shown as a function of weighted fiber diameter. The attempt to broaden the pore distribution by using combinations of fibers was a qualified success. Figure 2.1-5 shows that the breadth of the pore distribution increases with the weighted fiber diameter. 


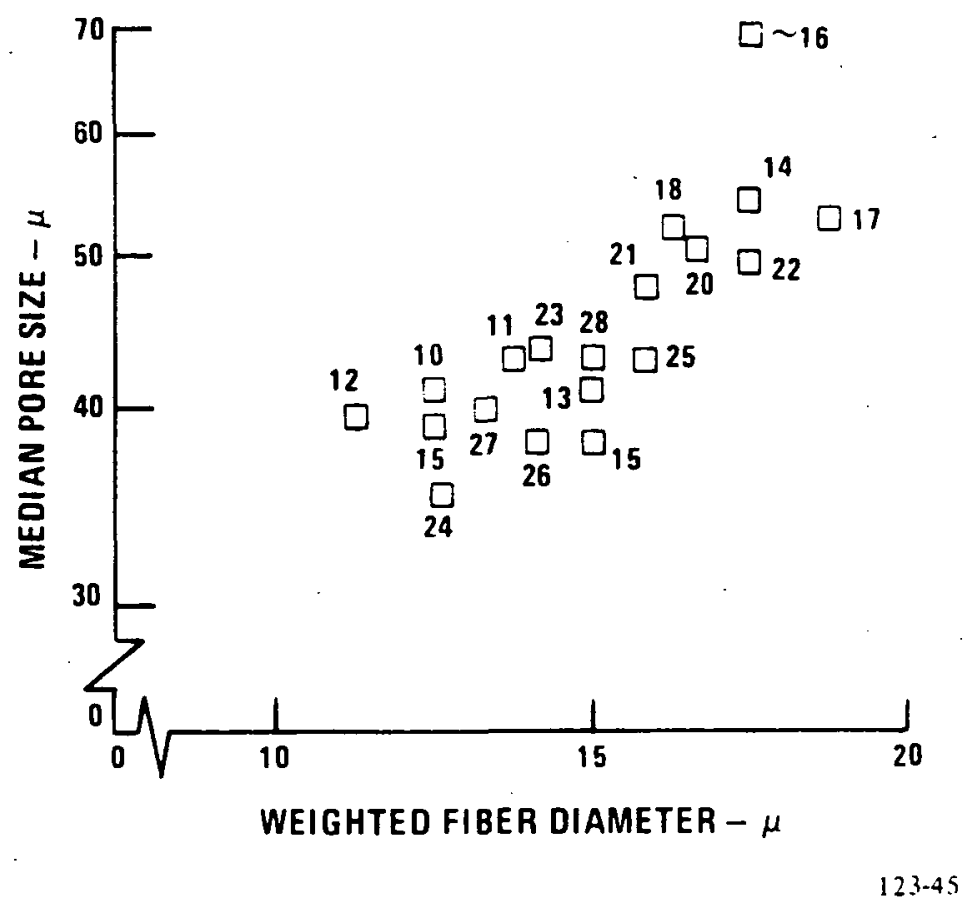

Figure 2.1-4 Median Pore Size vs. Weighted Fiber Diameter 


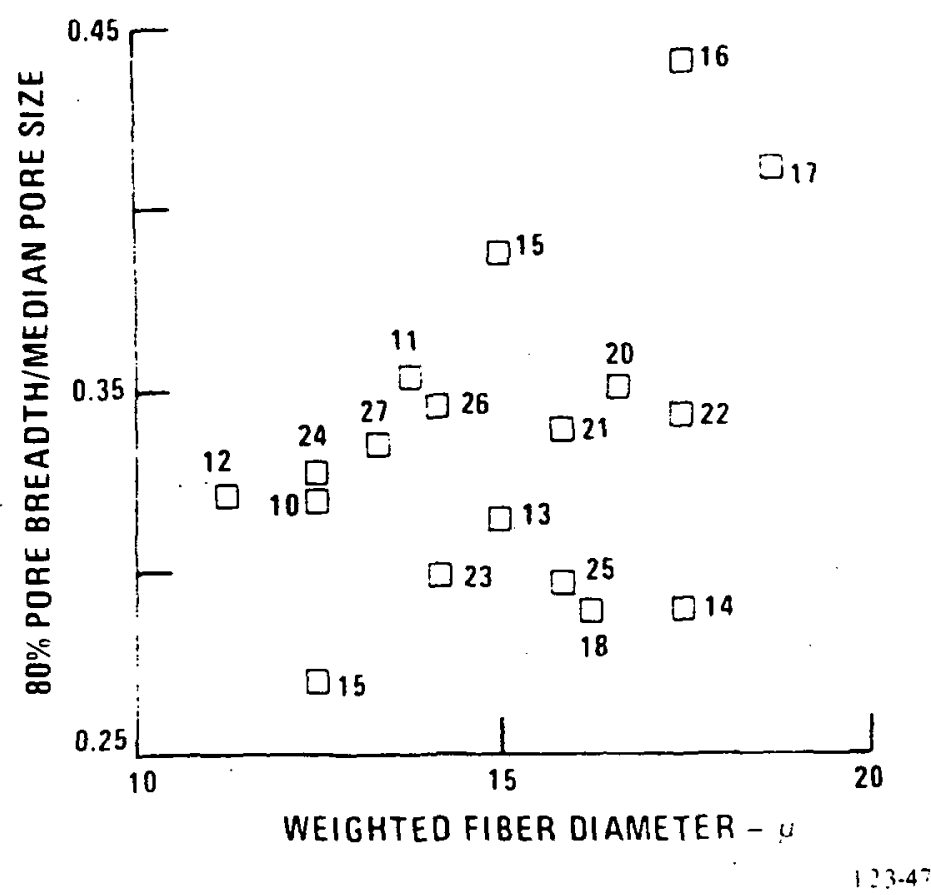

Figure 2.1-5 Breadth of Pore Distribution vs. Weighted Fiber Diameter 


\section{Low Cost Substrate Development}

The purpose of this effort is to develop a low cost replacement for the conventional graphite fiber-based material presently used in all acid power plants. In order to achieve the lowest possible cost, the approach taken was to identify vendors who could supply appropriate resin-impregnated fiber sheets on a mass produced basis.

These precursor sheets are then converted to useful fuel cell substrates through a series of processing steps.

Several candidate materials have been identified through efforts conducted in this and parallel programs to develop lower cost substrates. An analytical study was done to assess the effect of variations in substrate properties on power section cost. Table 2.1-2 shows the effect of thermal conductivity on power section cost.

The baseline is a substrate made from the standard pitch based carbon fiber with a nominal thermal conductivity of $4 \mathrm{Btu} / \mathrm{hr} \mathrm{ft}{ }^{\circ} \mathrm{F}$.

TABLE 2.1-2. EFFECT OF THERMAL CONDUCTIVITY ON POWER SECTION COST

Relative Thermal

Conductivity
Change in Power

Section Cost
0.25

0.50

1.00 (Baseline)

2.00

4.00
$+6.5 \%$

$+2.4$

0.0

$-1.6$

$-2.7$ 
Table 2.1-3 shows the variation of cell stack cost with substrate electrical conductivity performance differences. The baseline is a substrate made from the standard pitch based carbon fiber with a nominal resistance of $0.5 \times 10^{-2} \mathrm{mv} / \mathrm{mil}$ at $100 \mathrm{ASF}$. These analyses will be used in evaluating the candidate materials.

TABLE. 2.1-3. VARIATION OF STACK COST WITH ELECTRICAL CONDUCTIVITY

\begin{tabular}{ccc}
\hline $\begin{array}{c}\text { Change in Performance } \\
\text { at } 300 \mathrm{ASF}\end{array}$ & $\begin{array}{c}\text { Required Cel1 } \\
\text { Area }-\mathrm{Ft}^{2}\end{array}$ & $\begin{array}{c}\text { Change in } \\
\text { Power Section Cost }\end{array}$ \\
$-30 \mathrm{mV}$ & 4.6 & $+23 \%$ \\
-20 & 4.4 & +19 \\
-10 & 4.0 & +7 \\
$0($ Baseline $)$ & 3.7 & -10 \\
+10 & 3.3 & -19 \\
+20 & 3.0 & -27 \\
+30 & 2.7 & -10 \\
\hline
\end{tabular}

Three vendors having the potential to make the requisite precursor sheets have been identified. Test samples have been received from each of them. Samples from two of them have included variations in resin content and density. These have been processed into substrates, evaluated in out-of-cell tests and, in the case of the best materials, run in subscale cell tests.

In the course of this work it became apparent that the basic carbon structure generated from these precursor materials was less dense than the fiber employed in conventional substrates. This leads to lower thermal and electrical properties at comparable densities. On the other hand, the low cost materials are stronger. This has led to a series of compromises in order to achieve the most cost effective 
substrate. Figure 2.1-6 compares the properties of one of the best sample substrates to properties of substrates currently used in power plants.

It can be seen from these data that these new materials are stronger, but as yet do not meet the thermal, electrical, and corrosion properties of the conventional structures.

It was considered appropriate to address the next issue, scaleup to full size sheets, at this point in the program. This decision reflects both the expectation that further development will continue to improve the properties of the new materials, and the concern that the high shrinkage experienced by these precursor materials during heat treatment may lead to cracking or other types of distortion.

An experimental fabrication run of 50-inch by 50-inch sheets was ordered from the vendor. This is the maximum size that present heat treat tooling will allow. Initial heat treat trials with this material revealed a significant delamination problem. Delamination has not been seen in the test samples used in the earlier phase of the treatment. A modified process was developed that was evaluated with handsheets and found to give results similar to those found for the earlier process. An order was then placed for a second production run, this time employing the new process.

The order of approximately 150 sheets of the 50-inch by 50-inch size was recently received from the vendor. Thickness was not as uniform for this run. The edges of the sheets tended to be thicker than the centers. Half of the sheets were stacked in the heat treat furnace, taking care to minimize accumulations of high spots. No delaminations were observed, but only ten of the sheets survived without cracks.

The absence of any delaminations was encouraging. The cracking was believed to have occurred due to hang up of the high spots on the graphite fixtures. The remaining sheets will be microground to a uniform thickness prior to heat treatment. 


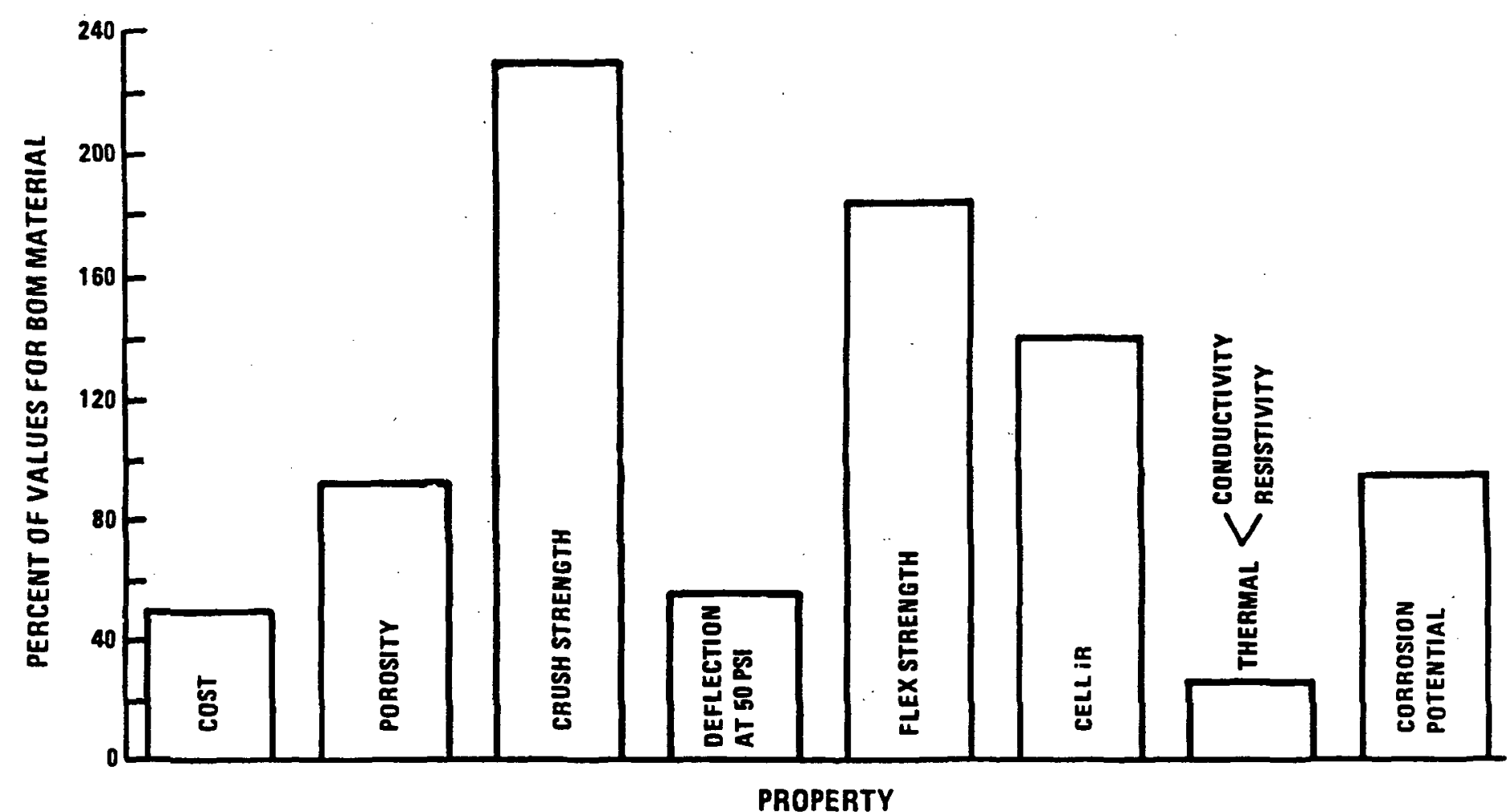

Figure 2.1-6 Low Cost Substrate Properties Compared to Properties of Substrates Used in Power Plants 
A third order has also been placed in order to demonstrate improved thickness uniformity and other minor changes. This material will be evaluated in the next report period. 


\section{Subtask 2.I - Cooler Technology}

\section{Objectives}

The objectives of this subtask are to reduce cooler cost while improving cooler reliability, and to minimize evaporative loss of electrolyte from the cell. Lower cooler cost will be addressed by increasing the number of cells per cooler, through enhanced heat transfer and advanced cooler design. Evaporative losses of acid will be minimized by designing the cell to have a lower exit temperature.

\section{Summary}

A totally encapsulated, single-element serpentine cooler has been successfully developed and is being tested in a 30-cell stack. By increasing the cells per cooler from five to ten, and by lowering cooler array costs by a factor of three, cooler costs were reduced by more than 80 percent. Cooler reliability was improved by encapsulating the cooler array in an acid-proofed enclosure and by eliminating the need for small diameter flow control orifices that would prevent cooler-tocooler flow maldistribution. The acid getter concept significantly reduced corrosion by $\mathrm{H}_{3} \mathrm{PO}_{4}$ in the cooler tube. Tests are being conducted to define the longterm burst pressure characteristics of the dielectric connector hoses.

Analytical predictions show that the acid condensation zone concept for reducing the acid evaporation rate from a cell has the potential to double the mean time between refills. This concept is being evaluated in a 30 -cell stack.

\section{Highlights}

- An encapsulated serpentine cooler was developed.

$\circ$

The encapsulated cooler increased reliability by eliminating flow control orifices. 


\section{Discussion}

Cooler development activities consisted of analytical studies to define the heat transfer and hydrodynamic characteristics of the serpentine cooler, testing of experimental cooler assemblies in the heat transfer rig to verify their thermal performance, fabrication of cooler assemblies for a 30-cell stack, materials testing to support advanced cooler concepts, and analysis of the acid condensation zone concept to reducing acid evaporation.

Cooler Design - The heat transfer characteristics of the $3 / 8$-inch bare metal serpentine cooler were analyzed. Design conditions were $400^{\circ} \mathrm{F}$ average cell temperature, $425^{\circ} \mathrm{F}$ hot spot temperature, $350^{\circ} \mathrm{F}$ water-steam coolant temperature, and performance corresponding to E-line $+20 \mathrm{mV}$ at $200 \mathrm{ASF}$. These conditions can be satisfied by a cooler spacing of 10 cells/cooler for substrates and cooler holders made from the standard pitch based carbon fiber.

The fluid dynamic analysis of the 3/8-inch tube diameter cooler was completed. The pressure drop across the cooler is about $7 \mathrm{psi}$, and the exit velocity is about 45 $\mathrm{ft} / \mathrm{sec}$ at rated power with $10 \mathrm{cells} / \mathrm{cooler}$ with a nominal exit quality of $10 \%$. The flow characteristics of this cooler configuration are such that flow control orifices are not required to prevent cooler-to-cooler flow maldistribution. A test program was initiated to define the influence of oxygen content and velocity on erosion-corrosion inside $3 / 8$-inch horizontal tubes.

The simplicity of the serpentine cooler results in a cost which is one-third of that of the conventional cooler. The 3/8-inch bare metal serpentine cooler allows the cells per cooler to be increased from five to ten. The combination of these results in a cost reduction of more than 80 percent when compared to the cooler configuration used in the $40-\mathrm{kW}$ power plant.

Heat Transfer Rig - The thermal resistance of an experimental cooler is determined by testing in a heat transfer rig. The rig contains electric heaters which provide a precisely measured heat flux to the cooler. A two-phase water-steam coolant is 
circulated through the cooler array at a flow rate of $40 \mathrm{lbs} / \mathrm{hr}$. The cooler assembly is instrumented with thermocouples to define the temperature at the outside surface of the cooler assembly and the coolant inlet and exit temperature. The thermal resistance is calculated from the measured heat flux and temperatures using a UTC-developed analytical model. The 3/8-inch $0 . D$. bare metal serpentine cooler was assembled in a cooler holder and tested in the heat transfer rig. The measured $\left(0.012 \mathrm{hr} \mathrm{ft}{ }^{2}{ }^{\circ} \mathrm{F} / \mathrm{Btu}\right.$ at 1.3 inch tube pitch) for this cooler was determined to agree with the predicted value used to establish the 10 cells per cooler spacing for the 30 -cell rig.

Fabrication of Cooler Assemblies for 30-Cell Stack - Cooler assemblies were fabricated for the 30 -cell stack tested in subtask 2.4. The assemblies contain a 3/8-inch single-element bare copper serpentine cooler array and a totally encapsulated cooler holder configuration. The design was developed under the GRI On-Site Technology Development Program. The design requires a 0.05 -inch thickness of graphite over gaps associated with the tube bends. Two 0.032 -inch thickness were used for this trial because of hardware availability.

The completely encapsulated cooler assemblies for the 30 -cell stack were characterized. The measured $i R$ across the cooler assemblies averaged $13 \mathrm{mV}$ at 100 ASF, which amortizes to $1.3 \mathrm{mV} / \mathrm{cell}$ at 10 cells per cooler. A gas leak check was made on each cooler assembly to check for leaks at the cooler tube penetrations between the bonded halves of the cooler holder. No leaks were observed. Application of an aggravated $100 \mathrm{psi}$ axial load did not initiate cracks in the sections of the plate associated with the tube bend gaps. Radiographs were obtained of each cooler assembly, which will serve as the basis for comparison at the planned 5000 hour inspection point.

Yaterials Testing - Support testing on advanced cooler concepts consisted of determination of burst pressure characteristics of Teflon ${ }^{\circledR}$ hoses, verification of effectiveness of acid proofing of encapsulated cooler, proof of concept test of acid getter approach, and initiation of a water-steam erosion-corrosion test. 
Dielectric Hoses - The coolers are connected to a coolant manifold with a dielectric hose to prevent electrical shorting. The 3/8-inch O.D. serpentine cooler and coolant operating conditions. require a Teflon hose with a 3/8-inch O.D. and a 0.150 -inch wall thickness. Tests were run to establish short-term and and long-term burst characteristics of this hose. Initial trials to clamp this hose to the cooler nipples were successful and showed no leakage at $600 \mathrm{psi}$ and room temperature. No leakage was measured after 15 thermal cycles from $70^{\circ} \mathrm{F}$ to $425^{\circ} \mathrm{F}$. Room temperature burst pressure is 1100-1200 psi, which translates to a 400-450 psi burst pressure at $400^{\circ} \mathrm{F}$.

Short-term burst pressure data was generated as a function of temperature. The results are:

No. of

Samples

1

1

2

1

\section{Temperature, ${ }^{\circ} \mathrm{F}$}

375

375

400

425
Burst

Pressure, psi

500

490

460

420

This burst pressure is adequate since maximum operating coolant pressure is 230 psi at $400^{\circ} \mathrm{F}$. Tests to define the long-term burst pressure characteristics of this hose are being conducted using procedures outlined in ASTM-D-2837 for evaluating thermoplastic hose materials. A subcontract was issued to a testing laboratory familiar with the ASTM-D-2837 procedure for distinguishing burst pressure characteristics of thermoplastic hose materials. Characterization of the long-term burst strength of the advanced 3/8-inch dielectric hoses continues. Burst strength is being determined as a function of time at temperatures of $350^{\circ} \mathrm{F}$ and $400^{\circ} \mathrm{F}$. Some of the samples have reached 3600 hours of a planned 10,000 hour test. Statistically significant data will be reported.

Verification of Encapsulated Cooler Concept - Mockups of encapsulated coolers were fabricated to evaluate the design's acid-proofing effectiveness. Three 12 -inch by 
12-inch mockups of the uncoated encapsulated cooler completed 2000 hours of testing at $375^{\circ} \mathrm{F}$ in a simulated stack acid environment. Acid take-up of the assemblies was low, approximately $20^{\circ}$ of the void volume of the separator plates. Comparison of radiographs taken at 2000 hours with pre-test radiographs showed no signs of corrosion. One assembly was dismantled and visually examined and there were no signs of corrosion.

Acid Getter - An acid getter was incorporated into the cooler assembly to protect the metal cooler tubes from corrosion in the event of an encapsulation failure. Corrosion tests were run to establish the effectiveness of this concept. This test simulates a failure of the cooler holder encapsulation. Samples were examined after 1000 and 3000 hours exposure to acid. In both cases the copper tube tested in the presence of the getter exhibited significantly less corrosion than a copper tube tested as a control.

Erosion-Corrosion - Coolant side corrosion of the cooler array is a concern due to the high velocities intrinsic in a single-element serpentine cooler. The heat transfer rig was redesigned to evaluate cooler erosion under controlled conditions. Major changes consist of increasing the power density of the heaters to increase the heat flux to the coolers, increasing the coolant flow from 40 to $200 \mathrm{lb} / \mathrm{hr}$, addition of a feedwater system that will allow the dissolved $\mathrm{O}_{2}$ level to be controlled, and the addition of ion-exchange beds that will allow $\mathrm{pH}$ to be controlled. A schematic of the test stand is shown in Figure 2.2-1. Construction and testing of the erosion-corrosion rig was completed. A stainless steel cooler array was obtained for evaluation in this rig and the rig was assembled. Testing will begin in Decenber 1983.

Acid Condensation Zone - Success in increasing cell performance in Task 1 will result in higher operation current densities and increased acid evaporation rates. The objective of the acid condensation zone is to lower the rate of acid evaporation from the stack. This is accomplished by lowering the air temperature at the cell exit. This approach was incorporated into the 30 -cell stack that is currently being rested. Anilytical predictions indicate the reduced acid loss will increase time iretheen acid replenishment by 85 percent, compared to conventional cell stack 
ORIGINAL PAGE IS

OF POOR QUALITY

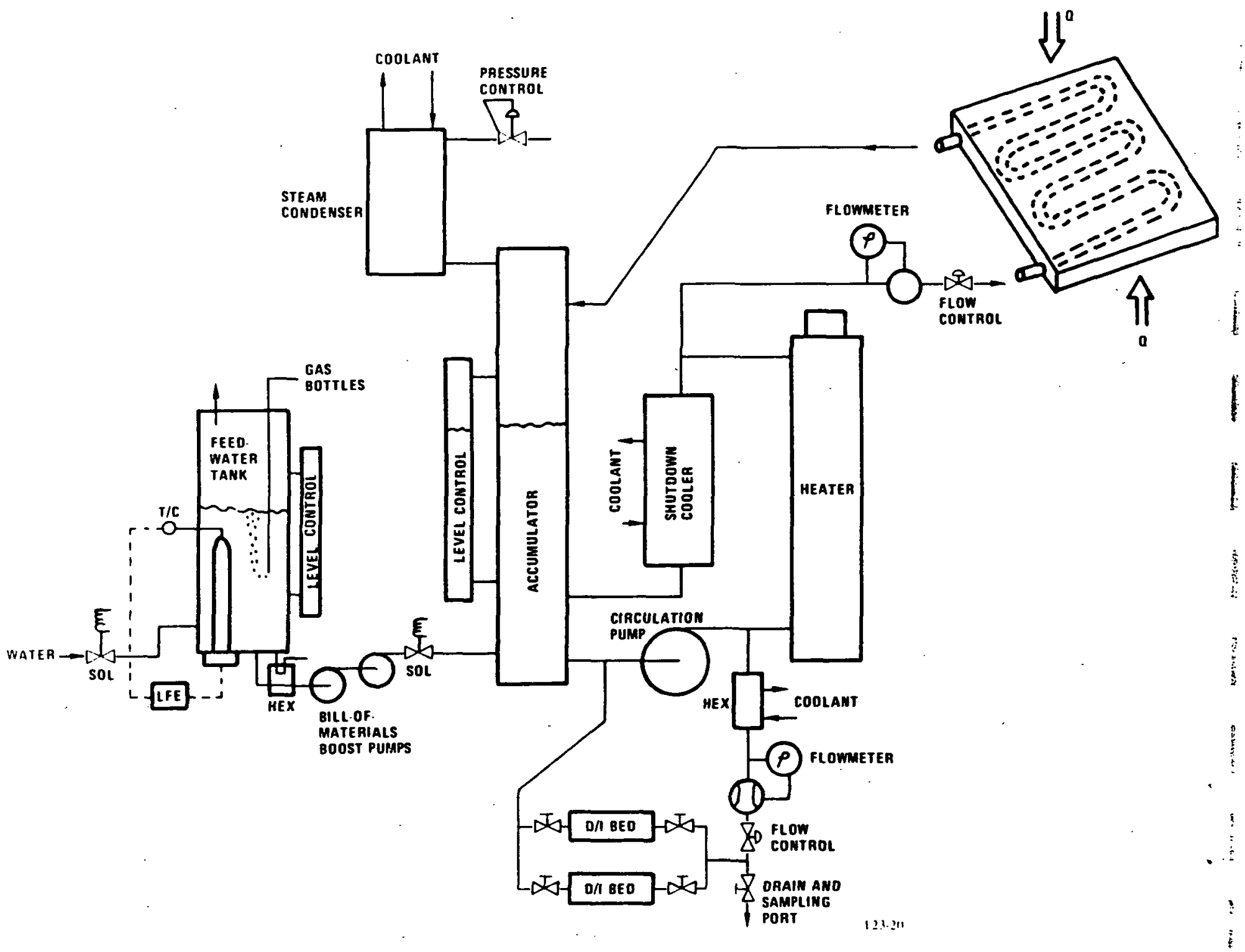

Figure 2.2-1 Test Stand Schematic 
designs where no special edge cooling is used. Plans are to test this stack 5000 hours and then dismantle it and obtain acid inventory data. The data obtained will be the basis for verifying this particular design. 
Subtask 2.3 - Non-Repeat Component Technology

\section{Objective}

The objective of this subtask is to extend stack overhaul period by developing a method of periodically adding electrolyte to the cells in the field. Subscale component tests will assess previously identified methods of electrolyte addition. The most promising approach compatible with the current cell and stack configuration will be evaluated in a non-operating stack of approximately 270 cells and in an operational short stack if appropriate.

\section{$\underline{\text { Summary }}$}

An approach to replenish acid in a stack was developed. Three refill concepts were previously identified under GRI contract 5080-344-0405: drip-wicking, acid injeclion, and spray. Ten-cell, quarter-scale mockups of the three concepts were evaluated. The spray approach was selected for trials on a $40-\mathrm{kW}$ stack after it was judged to be the fastest, most reliable, least sensitive to stack tilt, and having a moderate cost. The feasibility of the spray approach as a means to add acid was evaluated with a $270-c e l l 40-\mathrm{kW}$ size stack. The process was completed in one hour. This concept will be evaluated on the 30 -cell stack when it is rebuilt at 5000 hours to determine whether refill affects cell performance.

\section{Highlights}

- Evaluated drip-wick, acid injection, and spray approaches to acid addition in laboratory tests.

- Selected spray approach for trials on a 40-kW stack.

- Evaluated feasibility of acid refilling via the spray approach on a 270-cell 40-kli stack. 


\section{Discussion}

The three fill concepts have several common features: acid is added to a nonoperating stack, one electrode of each cell is saturated with dilute acid, and acid slowly redistributes within the cell as the acid is concentrated to operating concentration during a modified stack start-up cycle. The fill apparatus is the means to supply acid to each cell.

Drip-lick Approach - The drip-wick approach to acid addition is a subject of a patent disclosure, therefore, discussion of this approach must be limited at this time. Testing of a quarter-scale, 10-cell mockup of this approach resulted in fill within 30 minutes. Teardown confirmed the electrode substrates were saturated with acid.

Acid-Injection Approach - The acid injection approach adds acid to each cell by a small diameter Teflon ${ }^{3}$ tube. This tube is inserted into a reactant flow channel at each cell. The individual tubes are gathered into a bundle, and the bundle is sealed to form an acid distribution reservoir.

A quarter-scale, 12-cell mockup of this approach was evaluated. The test was run on a subscale stack consisting of three groups of cells separated by one foot spacers, giving a total height of two feet. The separator plates contained tabs. This was done to evaluate the effect of tube length on acid flow distribution. Acid flow through the tubes, which had lengths of 11,22 , and 33 inches, was found to be within $10^{\circ}$ o uniformity, with a 12 -inch acid head in the reservoir.

During acid addition, the flow channel containing the Teflon tube is the first to fill with acid. The acid flows out of this channel and is laterally transported across the face of the stack by the tabs on the separator plates. The acid is wicked into the cell by the reactant flow channels. The excess acid cascades down the face of the stack and is collected from the bottom of the reactant manifold. Again the cells were visually saturated with acid in about 30 minutes. The mockup was disassembled and gravimetrically verified that the substrates were saturated with acid. 
Spray Approach - The spray approach adds acid to the cell by spraying the face of the stack with acid.

A plexiglass manifold was built to fit the quarter-scale, 10 -cell mockup. Candidate spray nozzles were mounted into this manifold. Acid was applied to the face of the stack and hicked down the flow channels. Within 15 minutes the flow channels were visually saturated. Teardown analysis confirmed that the substrates were filled. lo obvious acid distribution or acid containment problems were observed.

Teflon is the preferred nozzle material because of its corrosion resistance. A test was run to evaluate the stability of the Teflon spray nozzles. The nozzles were aged in air at $400^{\circ} \mathrm{F}$. Determination of the spray pattern after 1000 and 1700 hours aging showed no deterioration of the spray pattern when compared to a new nozzle.

Selection of Approach for Full-Scale Mockup Test - The basic conclusion from the subscale work is that the drip-wick, spray, and acid injection concepts are all feasible. The rationale for selecting one approach over another comes down to cost and reliability. A qualitative comparison of three approaches is presented in Table $2.3-1$.

TABLE 2.3-1. COMPARISON OF ELECTROLYTE ADDITION APPROACHES

\begin{tabular}{|c|c|c|c|c|}
\hline $\begin{array}{c}\text { Refill } \\
\text { Approach }\end{array}$ & $\begin{array}{c}\text { Hardware } \\
\text { Complexity } \\
\& \text { Cost } \\
\end{array}$ & $\begin{array}{l}\text { Rate of } \\
\text { Refill } \\
\end{array}$ & $\begin{array}{c}\text { Sensitivity } \\
\text { to Stack Tilt } \\
\end{array}$ & $\begin{array}{c}\text { Estimated } \\
\text { Reliability }\end{array}$ \\
\hline Drip-Wick & Lowest & Slowest & Highest & Lowest \\
\hline Spray & Intermediate & Fastest & Lowest & Highest \\
\hline Injection & Highest & Intermediate & Intermediate & Intermediate \\
\hline
\end{tabular}

The spray approach is the fastest, most reliable, least sensitive to stack tilt, and has a moderate cost. This approach was selected for evaluation in a 270 -cell mockup. 


\section{Acid Addition to $40-\mathrm{kh}$ Stack}

Acid refill trials were conducted on a used $270-c e l 140-k W$ stack to evaluate the feasibility of the overall refill approach. Approximately 100 cells were replaced with new cells. The new cells were filled with varying amounts of acid; some cells were empty, while others were 10,20 , and $30^{\circ}$ full. These cells were assembled into six-cell substacks, and the substacks were located throughout the entire stack. A reactant manifold was modified to contain four spray nozzles, and plexiglass sections were installed on two manifolds to permit visibility during the spray refill process. The suitability of the spray nozzles and support equipment was verified using $50^{\circ} \mathrm{H}_{3} \mathrm{PO}_{4}$. A teardown inspection will then be conducted to determine the acid inventory of each specially filled cell.

An acid addition trial was completed on this stack. A photograph of the acid spray rig is shown in Figure 2.3-1. A total of 19.6 gallons of $50 \% \mathrm{H}_{3} \mathrm{PO}_{4}$ was added to the stack in approximately 63 minutes, and the acid was sprayed at a rate of approximately $0.5 \mathrm{gpm}$. The reactant flow channels on the electrode exposed to the acid spray were all visually filled with acid at the end of this period. Excess acid present on the separator plate tabs when the flow was stopped was absorbed by the cells in a period of 60 minutes. The acid was contained in the reactant manifolds. There was no external leakage of electrolyte and no operational problems were noted. lo shunt currents were observed after the refill cycle had been completed.

The acid in the stack will be concentrated from $50 \%$ to $80 \% \mathrm{H}_{3} \mathrm{PO}_{4}$ by flowing inert gas across the stack. The stack will then be disassembled and the acid gained by each cell determined gravimetrically.

\section{Subtask 2.4 - Cell Stack Testing}

\section{Objective}

The objective of this task is to evaluate previously developed stack components in a 30 -cell stack. This stack will be used to evaluate the performance and decay characteristics of electrodes containing advanced catalysts at on-site power plant 


\section{ORIGINAL PAGE IS \\ OF POOR QUALITY}

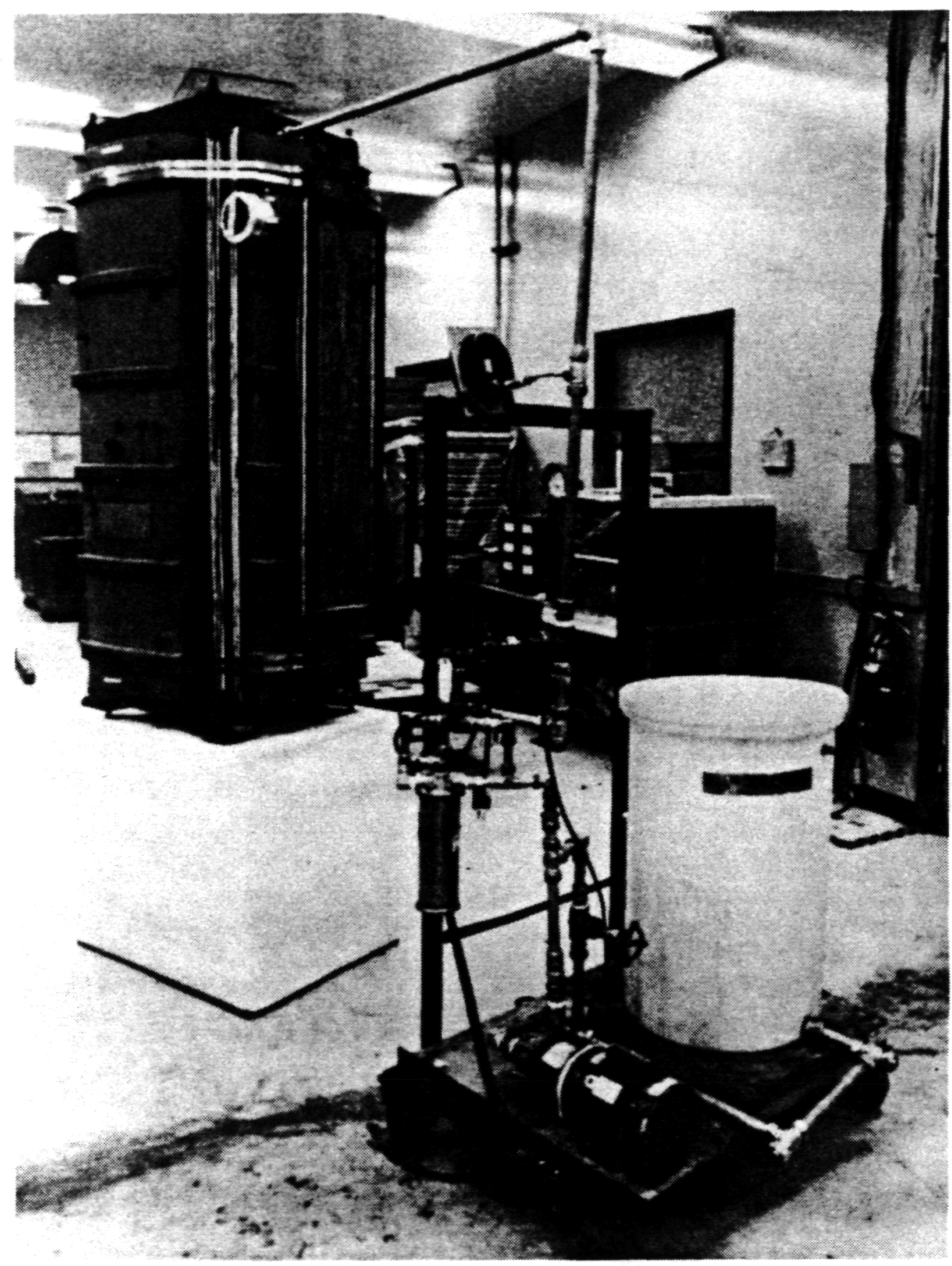

WCN-10844

Figure 2.3-1 Acid Replenishment Test Rig 
operating conditions. The components in this stack contain advanced features developed in this program and in parallel programs. The test program will be conducted for 5000 hours, after which the stack will be disassembled and a nondestructive post-test analysis will be performed on the components. The stack will be reassembled for additional testing if judged useful and if the components are acceptable.

\section{Summary}

An advanced technology 30 -cell stack with a $3.2-\mathrm{ft}^{2}$ active area was fabricated, assembled, and tested. Component features being evaluated are a totally encapsulated, single-element serpentine cooler at 10 cells/cooler; electrodes containing an acid condensation zone and acid refill provisions; a GSB-18 cathode catalyst with wet $\operatorname{mix}$ and dry mix formulations; substrates made with two-stage resin; lower cost silicon carbide in matrix; and a new end plate configuration. The stack was tested at $14.7 \mathrm{psia}, 400^{\circ} \mathrm{F}$ average cell temperature, and at $200 \mathrm{ASF}$. Test time was 2900 hours at the end of November, and the test is continuing. Performance of the encapsulated cooler met design requirements at 10 cells/cooler. Performance was 5-10 $\mathrm{ml}$ below E-line and tracked E-line for 2900 hours. Performance and stability of the dry mix electrodes was equal to the wet mix electrodes. Two PPS-coated steel manifolds were installed on the stack at 2700 hours. The test program will continue to 5000 hours, after which the stack will be disassembled and a non-destructive post-test analysis will be performed on the components. The stack will be reassembled for additional testing if judged useful and if the components are acceptable.

\section{Highlights}

- Tested an advanced technology 30-cell stack for 2900 hours at 14.7 psia, $400^{\circ} \mathrm{F}$, and $200 \mathrm{ASF}$.

- Totally encapsulated, single-element serpentine cooler performance met design requirements at $10 \mathrm{cells} / \mathrm{cooler}$. 

Electrodes contained an acid condensation zone to minimize acid evaporation and also contained acid refill provisions.

Performance was 5-10 $\mathrm{mV}$ below E-1ine and tracked E-line for 2900 hours.

Performance and stability of the dry mix electrodes was equal to the wet mix electrode.

\section{Discussion}

An adranced technology 30-cell stack was fabricated, assembled, and endurance tested for 2900 hours. This 30 -cell stack contains the following special features:

- Thirty cells with GSB-18 cathode catalyst and HYCAN anode catalyst. Both dry mix and wet mix anode and cathode catalyst formulations are being evaluated.

- Totally encapsulated, single-element uncoated serpentine coolers with 10 cells per cooler.

- Acid condensation zone to reduce acid loss.

$\circ$ Acid refillable cell configuration.

- End plate cell contact surface formed by bonding half cooler holder to porous carbon end plate.

$\circ$ Carbon fiber material used to achieve low resistance contact between end plate and current collectors.

- Lower cost matrix material.

A photograph of this stack is presented in Figure 2.4-1, which shows the completed stack assembly prior to installing the thermal insulation and connecting to the test facility. 


\section{ORIGINAL PAGE IS OF POOR QUALITY}

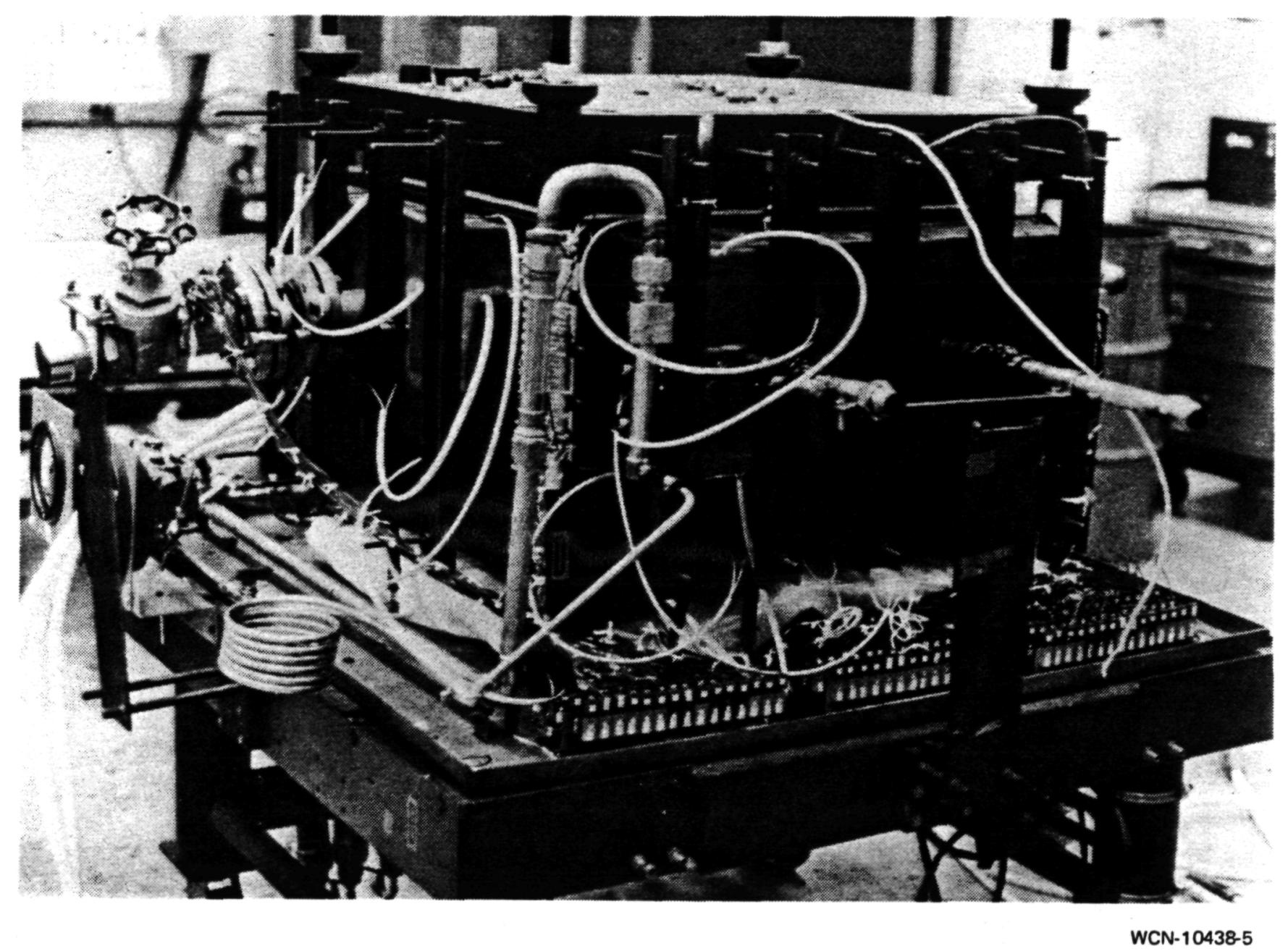

Figure 2.4-1 Stack Assembly, Prior to Thermal Insulation 
The endurance test is being conducted at 14.7 psia reactant pressure and at $400^{\circ} \mathrm{F}$ average cell temperature. The cell operating conditions are $200 \mathrm{ASF}, 80^{\circ}$ fuel utilization, $60^{\circ}$ air utilization, and $148^{\circ} \mathrm{F}$ fuel dew point.

The performance characteristics of this stack have been documented by a series of diagnostic tests that were run at 300,1200 , and 2800 hours of operation. These diagnostic tests include a cell performance calibration, cell performance change with test time, reactant gas utilization sensitivity to cell performance, anode and cathode performance gains for pure reactant gases, reactant gas crossover and leakage, cell package electrical resistance, cell and stack thermal profile, and axial load reduction with test time. (Cathode oxygen gain measurement is run only at 3000 and 5000 hours because of the difficulty of the test.)

The cell performance calibration data compared to E-line performance is presented in Figure 2.4-2. The cell performance history is presented in Figure 2.4-3. This data is also compared to the E-line performance goal decay rate and it indicates that the performance is stable and 5 to $10 \mathrm{mV}$ below the goal through 2900 hours of operation. The cell to cell performance variation is presented in Figure 2.4-4. This indicates that the performance level of the different types of catalyst formulations is essentially the same. The performance difference that is indicated in this data is due to the differences in the cooler assembly electrical resistance.

The reactant gas utilization effect on cell performance is presented in Figure 2.4-5. This indicates that the change in cell voltage is at the predicted or theoretical leve1.

The anode and cathode performance gain for pure reactant gases is presented in Figure 2.4-6. The cathode performance gain was documented at 300 hours. The anode performance gain was documented at both 300 and 2800 hours. This indicates that there is no change in the anode performance. The anode and cathode performance gains are also at the expected levels for these types of anode and cathode catalysts. 


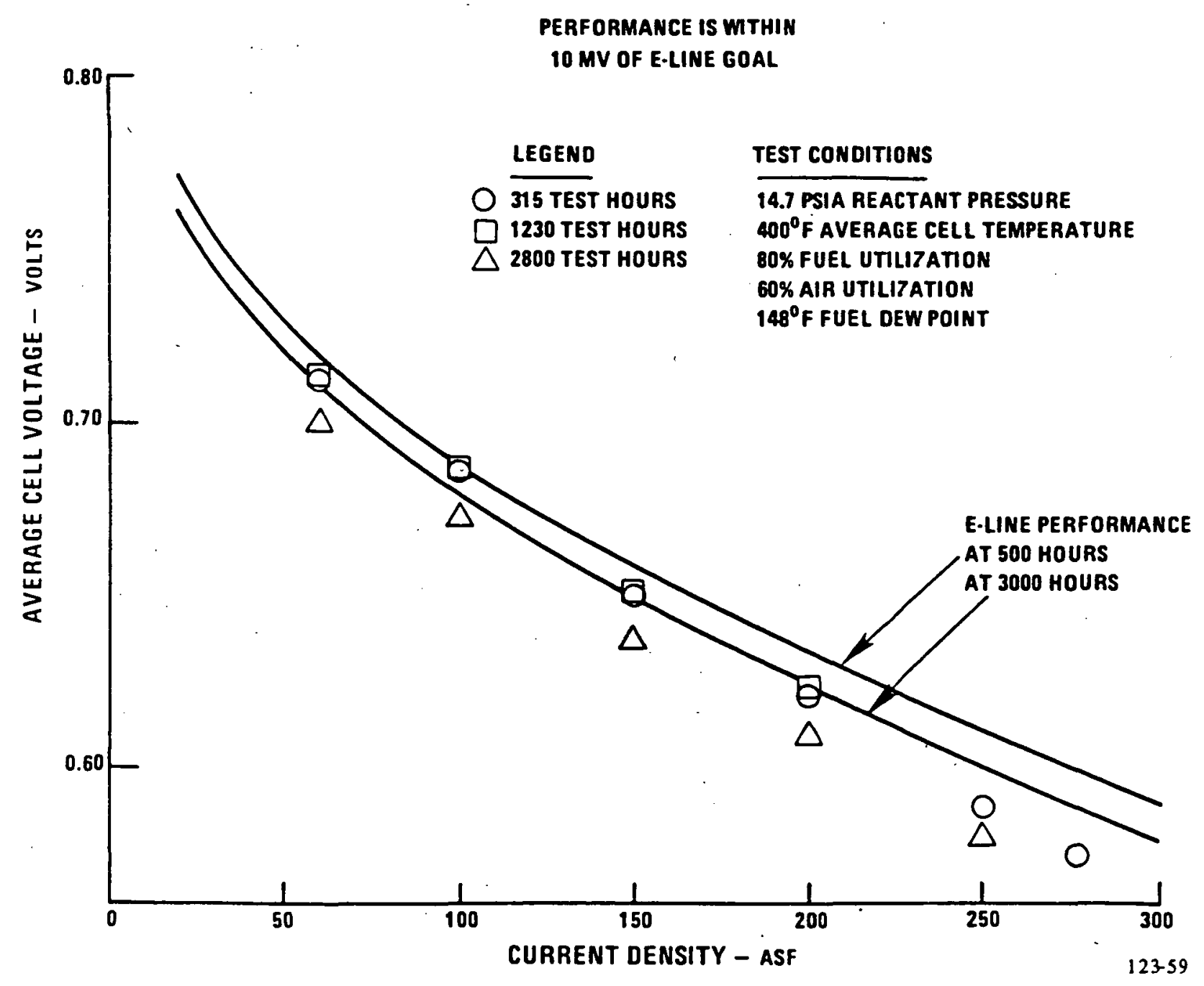

Figure 2.4-2 Average Cell Voltage vs. Current Density 

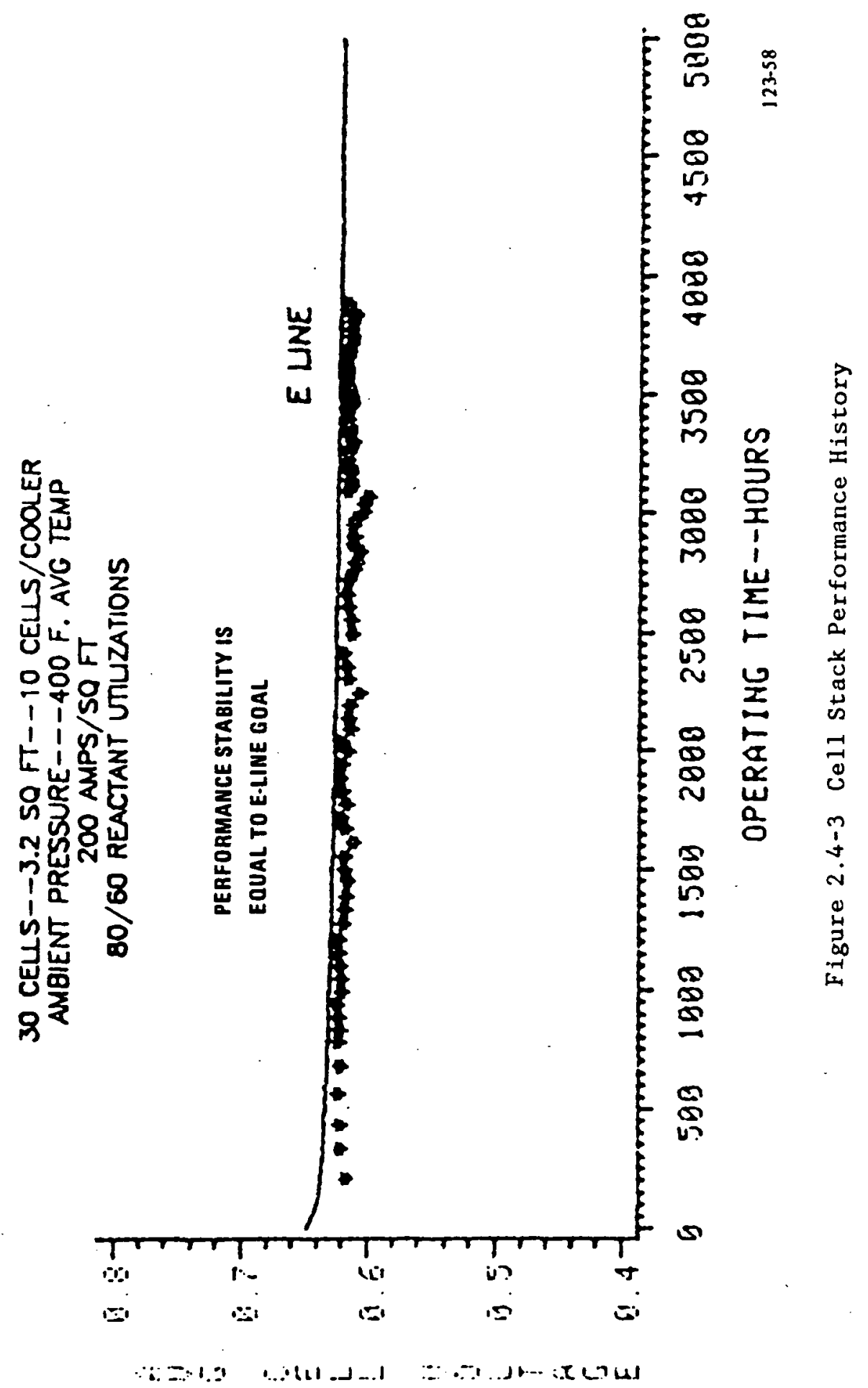


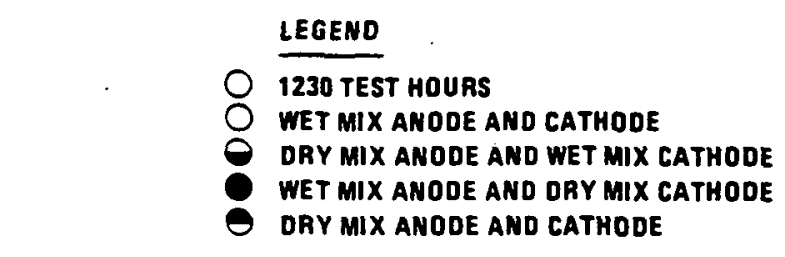

TEST CONDITIONS

14.7 PSIA REACTANT PRESSURES $400^{\circ} \mathrm{F}$ ÁVERAGE CELL TEMPERATURE 80\% FUEL UTILIZATION 60\% AIR UTILIZATION $148^{\circ}$ F FUEL DEW POINT 200 ASF

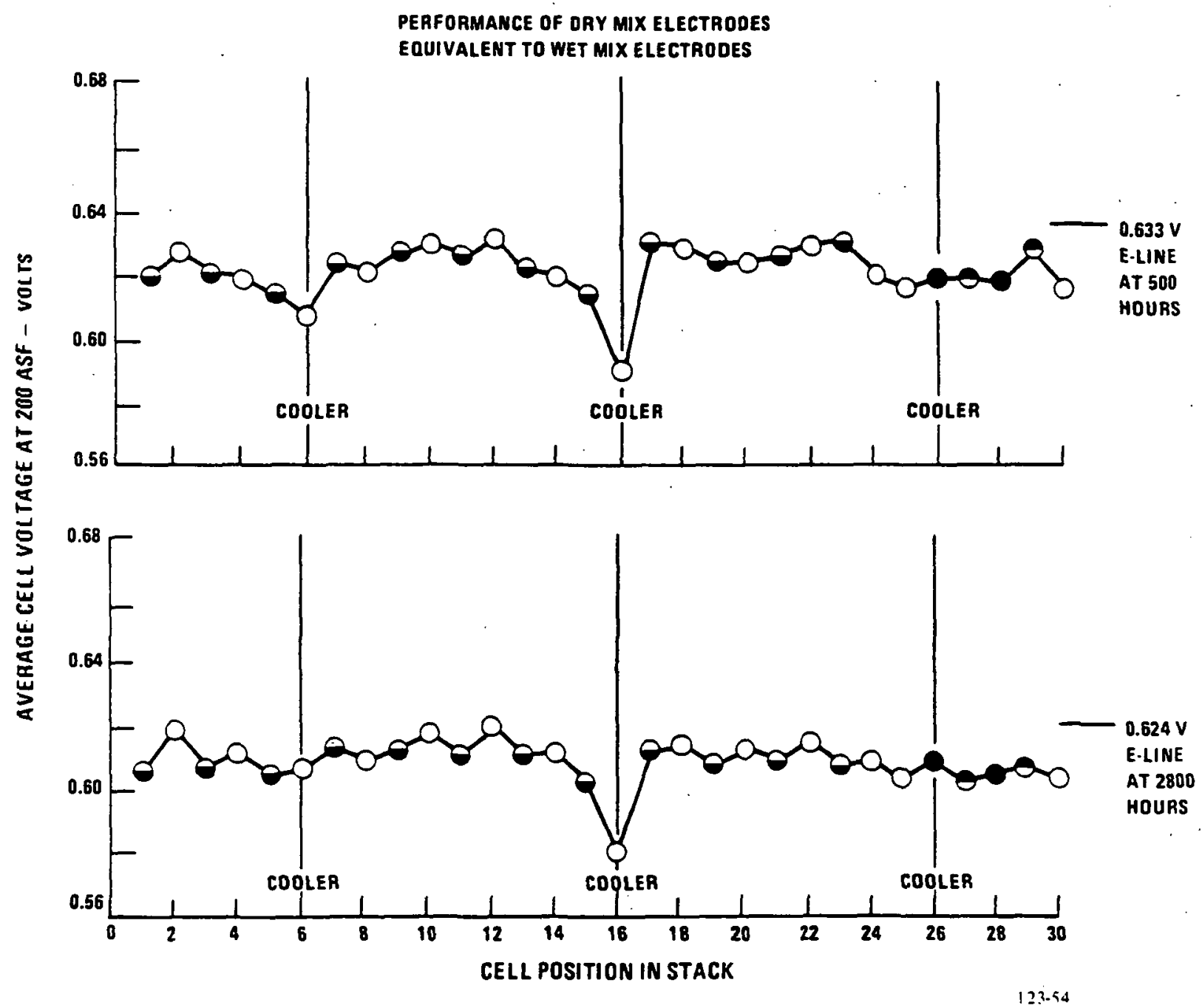

Figure 2.4-4 Cell Performance vs. Cell Position 

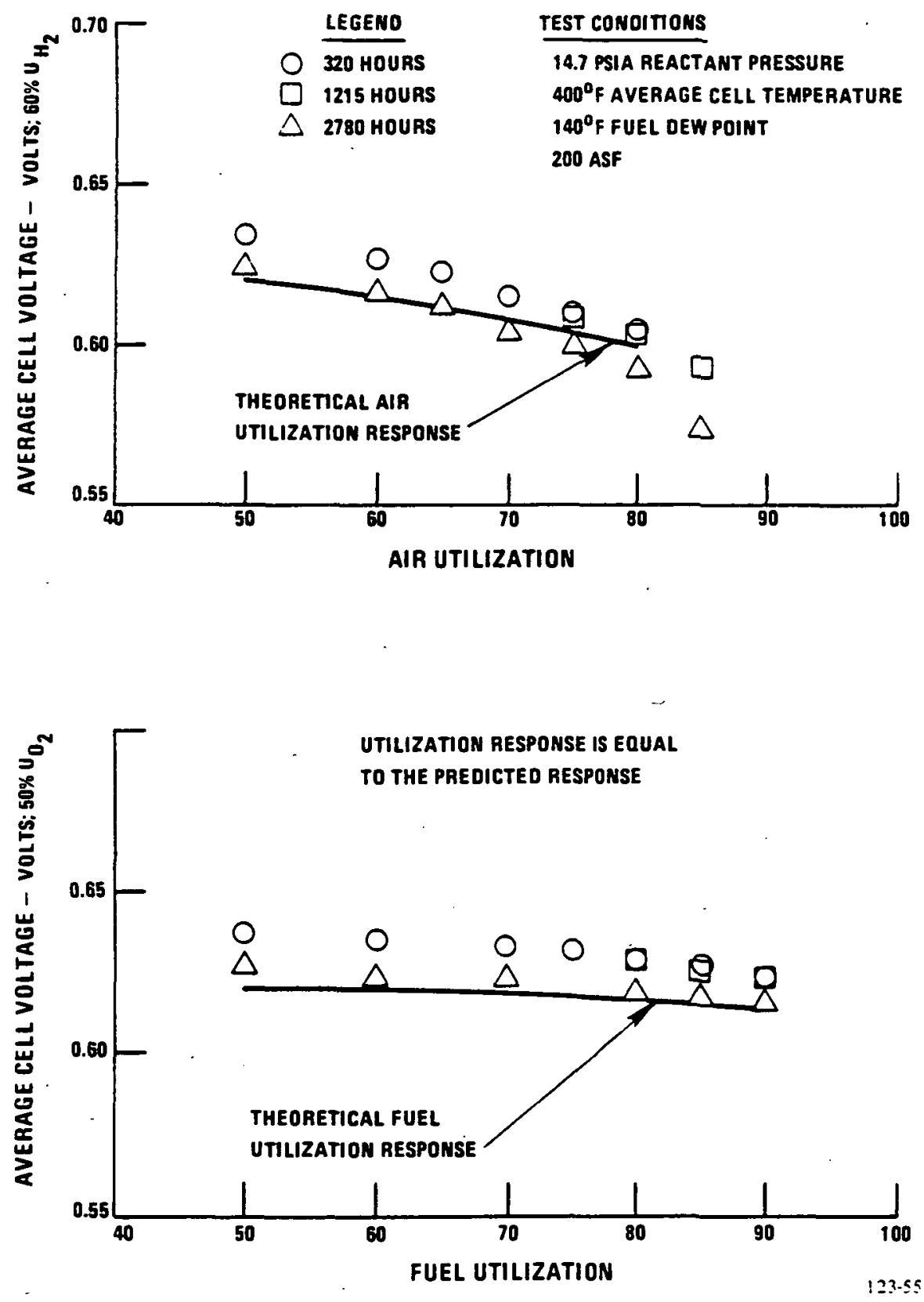

Figure 2.4-5 Reactant Gas Utilization vs. Average Cell Voltage 
$\frac{\text { LEGEND }}{335 \text { HOURS }}$
$\triangle 2798$ HOURS

\section{TEST CONDITIONS}

14.7 PSIA REACTANT PRESSURES

$400^{\circ} \mathrm{F}$ AVERAGE CELL TEMPERATURE

$148^{\circ} \mathrm{F}$ FUEL DEW POINT

200ASF

50/50 UTILIZATION

CATHODE PERFORMANCE GAIN $\mathrm{H}_{2}$ /AIA TO $\mathrm{H}_{2} / \mathrm{O}_{2}$

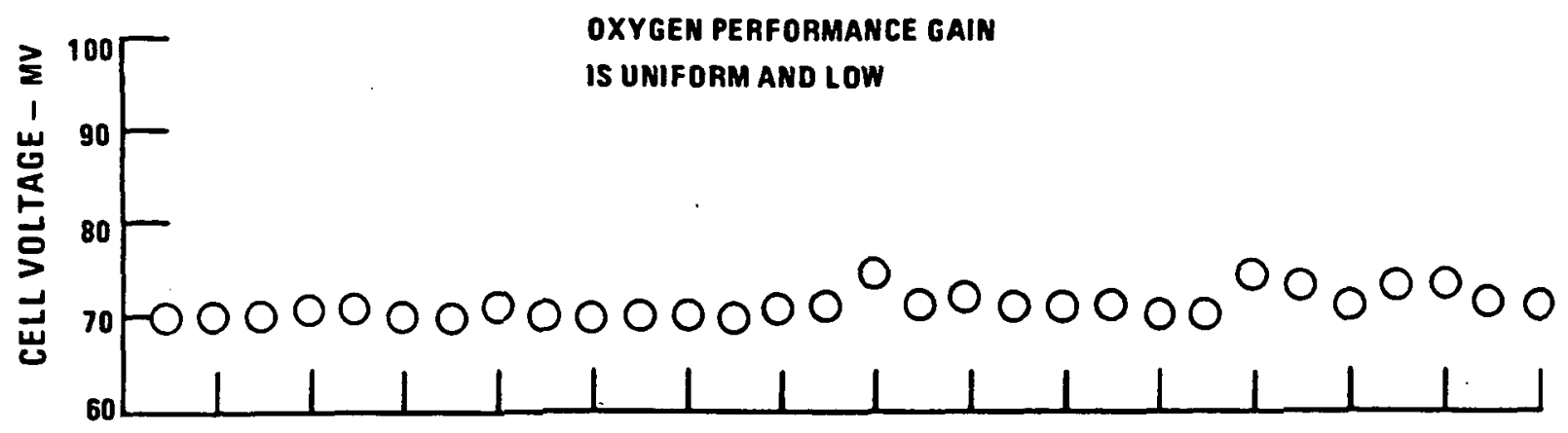

ANOdE PERFORMANCE GAIN RL-1/ $\mathrm{O}_{2} \mathrm{TO}_{2} / \mathrm{O}_{2}$

HYDROGEN PERFORMANCE GAIN

IS Stable mth OpERATng time
$=$
$=$

CELL POSITION IN STACK

Figure 2.4-6 Anode and Cathode Performance Gain for Pure Reactants 
The reactant gas crossover leakage is presented in Figure 2.4-7. This figure presents the cross-leakage measured as a change in the open circuit voltage for a change in reactant gas cross-pressures. This indicates that the cross-leakage is very low and at an acceptable level in each cell. The total reactant leakage for the stack is $0.01^{\circ}$ of fuel flow at rated power for a one inch of waier cross-pressure, which is unchanged through 2900 hours of operation.

The cell package electrical resistance data is presented in Figure 2.4-8. The average $i R$ for both the cells with separator plates and the cells with cooler assemblies is at the predicted levels. The cell iR has not changed through 2800 hours of operation.

The cell and stack thermal profile data are presented in Figure 2.4-9. The data indicated that the thermal data within a cell and within the stack are at the design level. This indicates that the thermal performance of the encapsulated cooler meets the design requirements and that this thermal performance has remained constant through 2900 hours of operation. These data also show that acid condensation zone cemperatures are being achieved.

The stack axial load reduction with operating time is presented in Figure 2.4-10. The reduction in axial load is at the expected level.

The endurance test for this stack was interrupted after 2700 hours of operation. At this time the air exit and fuel in/out manifolds were removed, and manifolds fabricated of carbon steel with a PPS protective coating were installed. An acid scrubber was also installed in the air exhaust for measurement of the acid loss rate from the stack.

The endurance test program is continuing. Over 2900 hours of operation have been accumulated, including 10 thermal cycles. This endurance program will continue until 5000 hours have been accumulated, after which time the stack will be disassembled and a non-destructive post-test analysis will be performed on the components. The acid loss rate will be determined and compared to predictions to establish the effectiveness of the acid condensation zone. The effectiveness of the 
OPEN CIRCUIT VOLTAGE RESPONSE FOR REACTANT

GAS PRESSURE CHANGE OF \pm 2 INCHES OF WATER
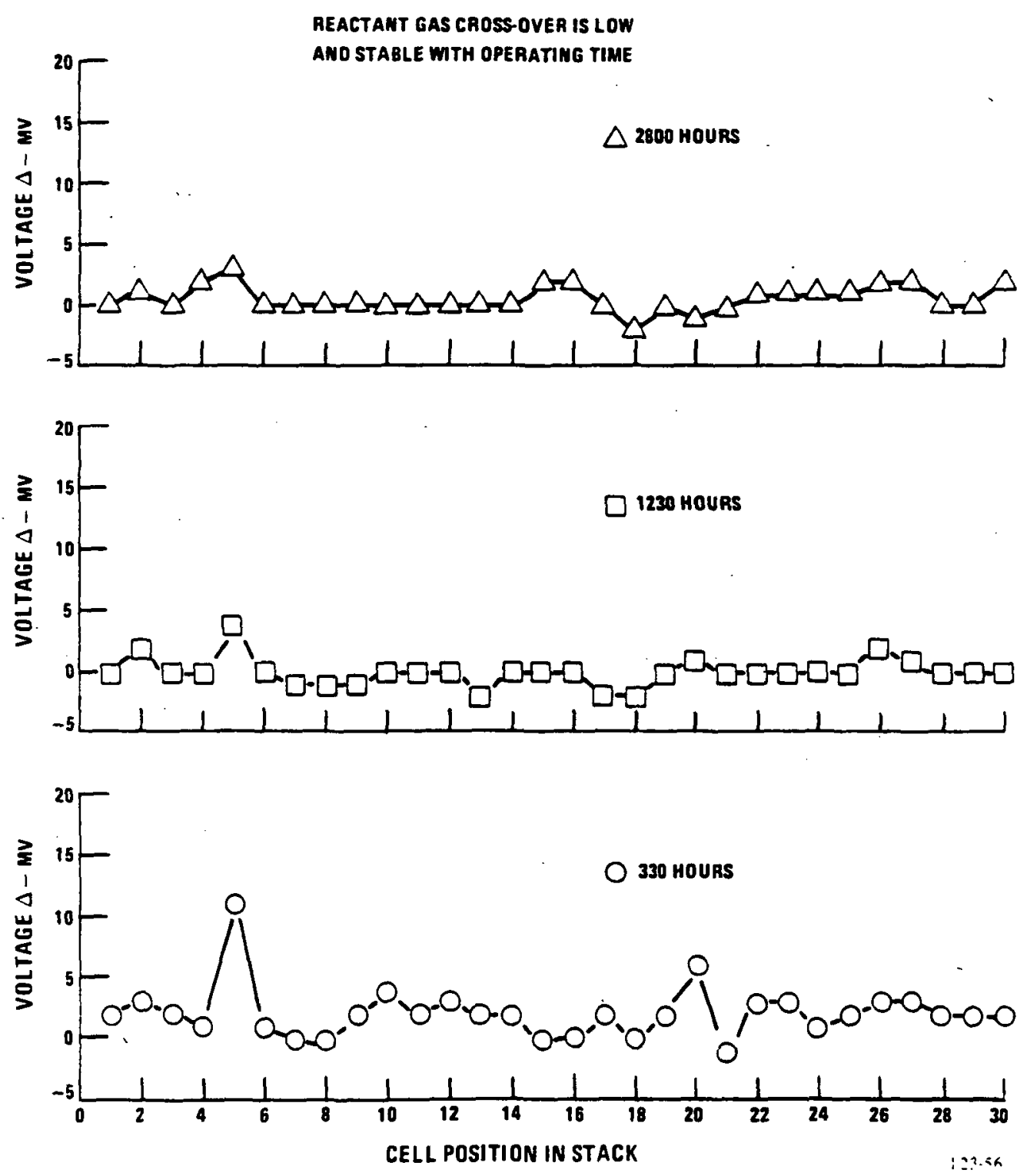

Figure 2.4-7 Reactant Gas Cross-Leakage Test 


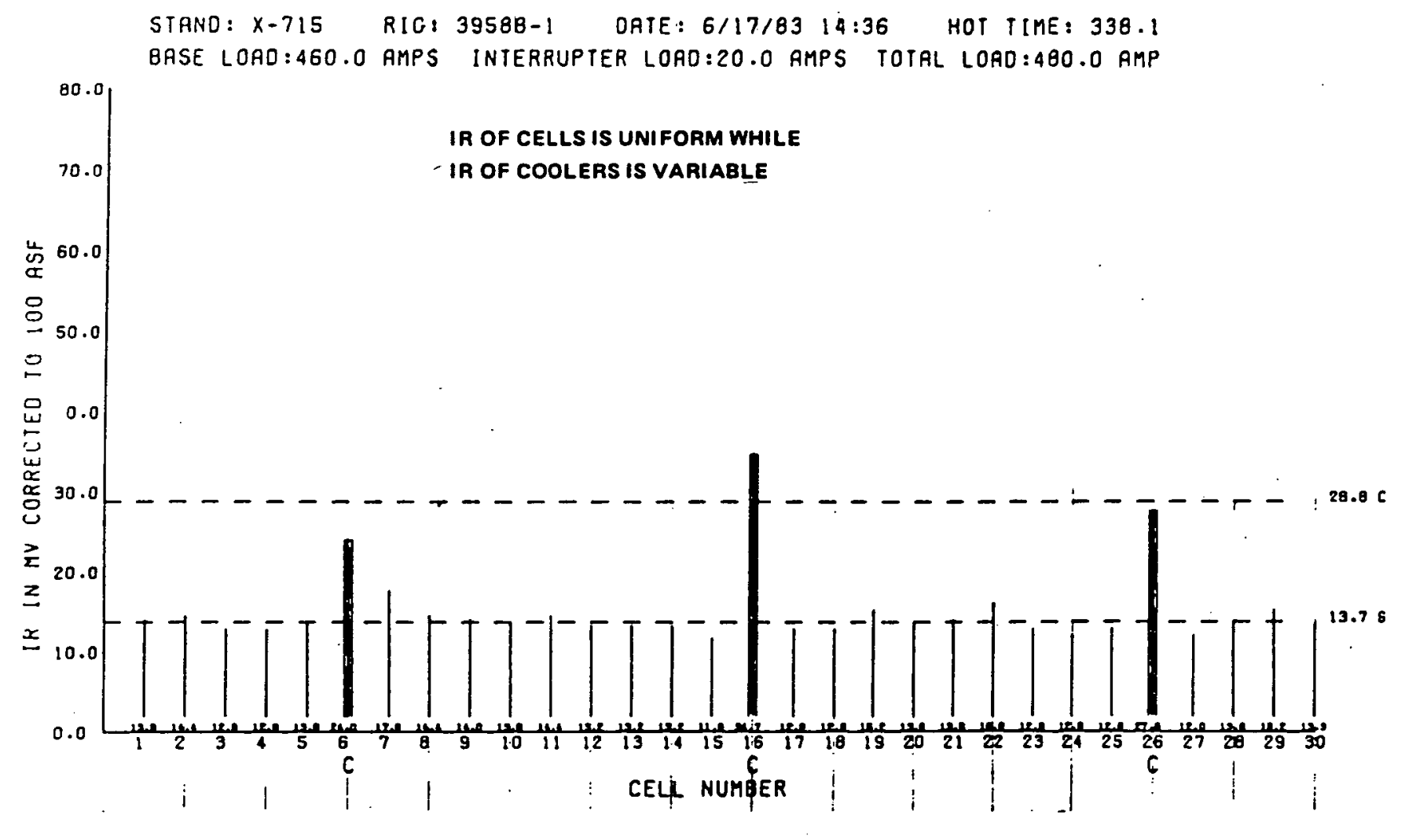

123-57

Figure 2.4-8 iR vs. Cell Position 


\section{CELL ANO STACK THERMAL PROFILE AT THE PREOICTEO LEVEL}

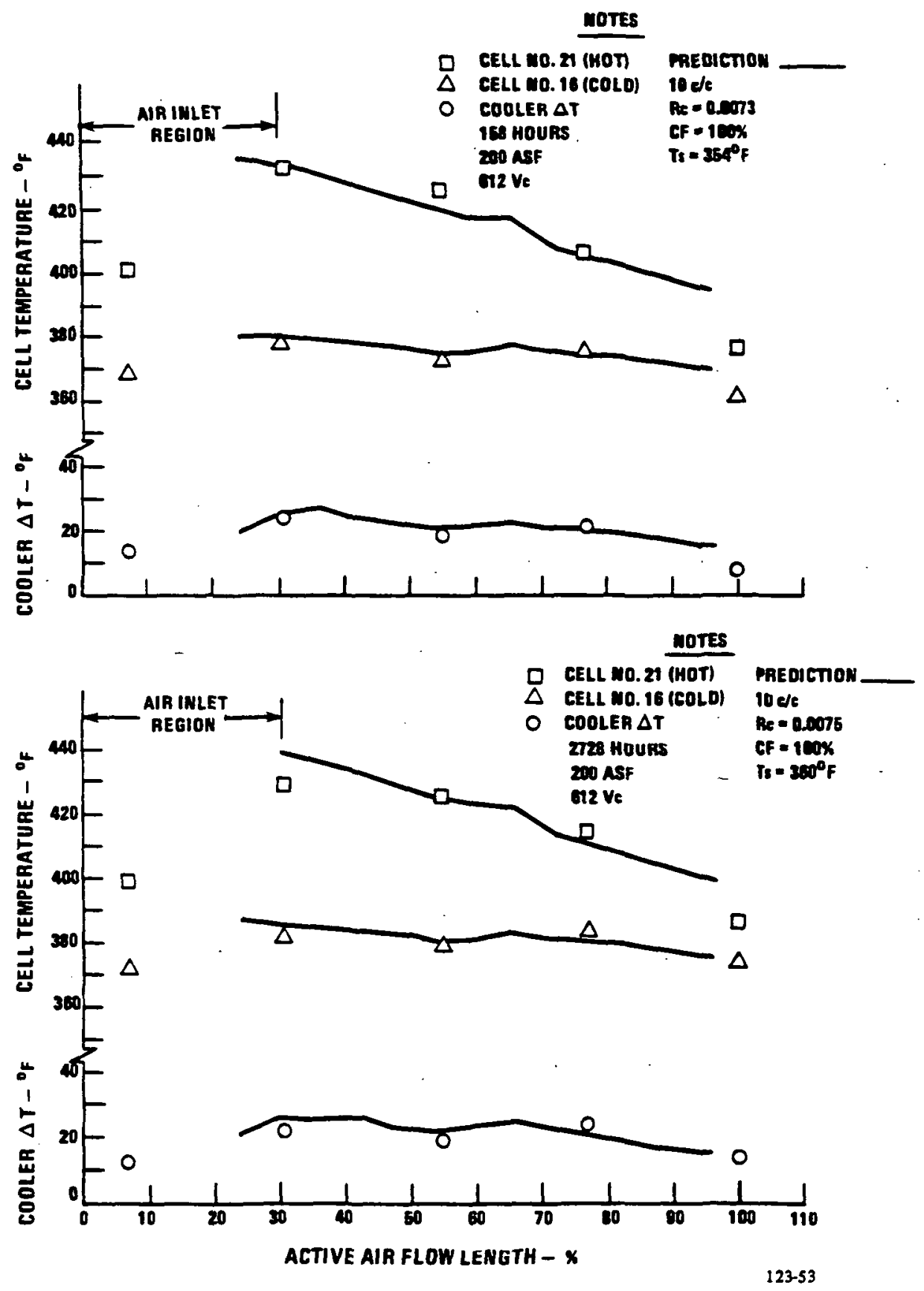

Figure 2.4-9 Cel1 Temperature Distribution 


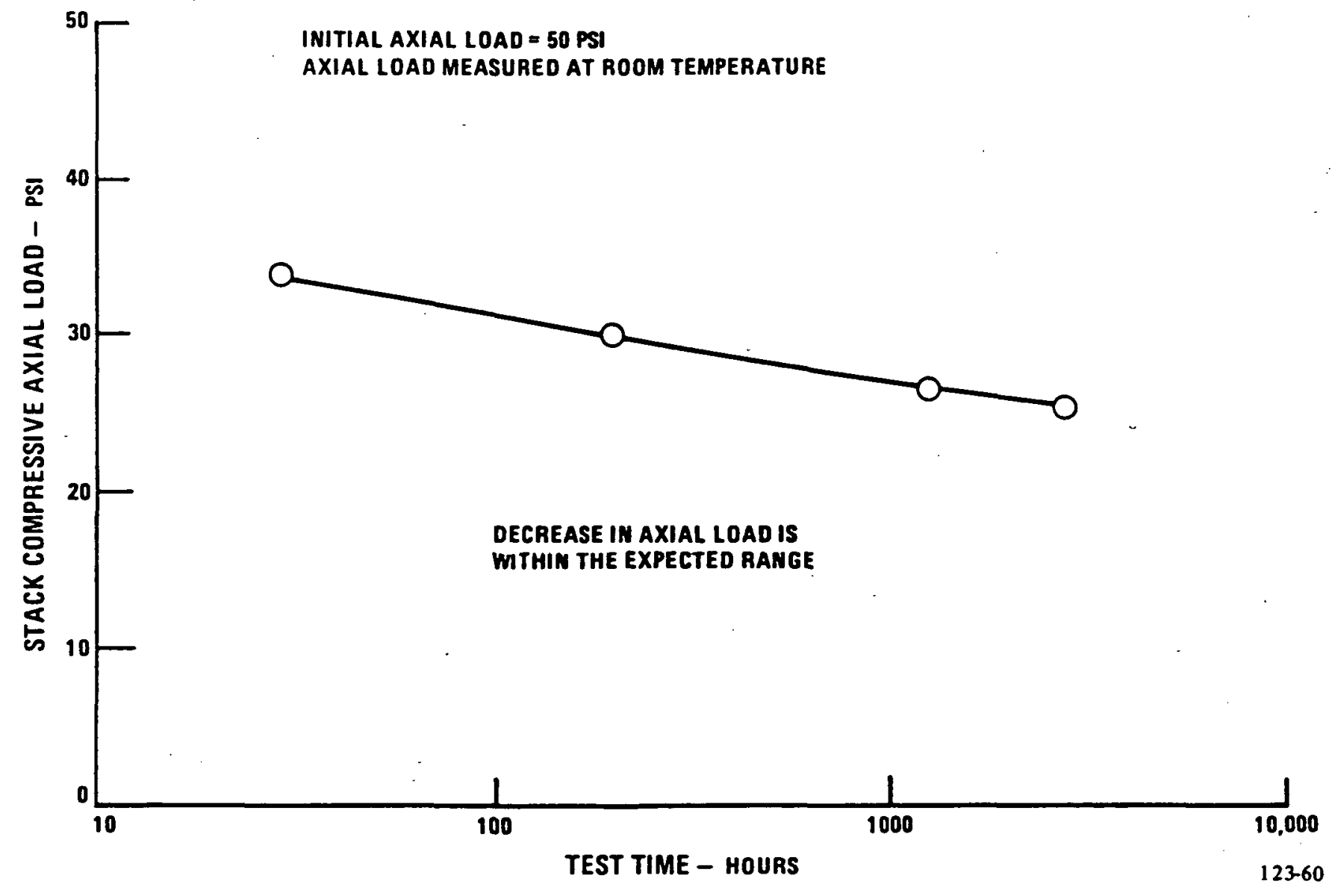

Figure 2.4-10 Axial Load vs. Test Time 
acid-proofing concept for the cooler will be established. Also, at this time an acid refill test $\mathrm{will}$ be conducted to evaluate the acid refill procedure being developed under Subtask 2.3. The stack will then be reassembled for additional testing if judged useful and if the components are acceptable. 
TASK 3 POWER PROCESSOR DEVELOPMENT

1

1

i

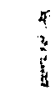

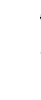

1 
TASK 3 - POWER PROCESSOR DEVELOPMENT

\section{Subtask 3.1 Define Inverter Technology}

\section{Objective}

The objective of this subtask is to establish the design approach, control circuit options, and semiconductor technology for a high efficiency, low cost inverter.

\section{Summary}

The approach taken in this subtask was first to evaluate the impact of advanced semiconductor and power circuit technologies, control concepts, and improved magnetic components on inverter cost and efficiency. The basic inverter electrical power circuit design, as established in the 1982 GRI program, was modified and updated as a result of these optimization studies, system tradeoff studies, and identified beneficial technologies. A detailed electrical design was then established, along with a GRI-sponsored conceptual mechanical packaging design, for use in performance estimates and a subsequent cooling study.

The resulting design is a two-bridge, 200-kW inverter which, with auxiliary commutation for surge circuitry and a low loss output transformer, has a calculated full load efficiency of $94.8 \%$. Use of more advanced asymmetrical silicon controlled rectifiers ( $A S C R$ 's), expected to be available in the future, will result in a calculated $95.4 \%$ efficiency. The cooling study found conventional forced air cooling to be the best choice, based on acceptable performance, cost, and parasitic losses.

\section{Highlights}

- Established a bridge electrical design that results in a calculated full load inverter efficiency of $94.8 \%$.

- Selected conventional forced air cooling for the bridges. 
- Identified the efficiency benefits of auxiliary commutation for surge as $0.2 \%$ at full load and $1.0 \%$ at quarter load, and of a low loss output transformer as $1.0 \%$ at full load.

- Selected ASCR's for use in the brassboard inverter, identified expected efficiency improvements resulting from near term ASCR's, and selected GTO's for laboratory evaluation.

\section{Discussion}

Previous studies performed under a GRI-sponsored effort evaluated power circuit technology and identified designs that would improve cost and/or efficiency. The study determined that the individual commutation circuit provided both cost and efficiency advantages over the Split-C commutation circuit used in the 40-kW on-site invertér. The 40-kW inverter utilizes a dc-to-dc converter stage to provide regulated dc input to the inverter stage. This two-stage design was found to be unnecessary for the advanced on-site inverter, because the on-site fuel cell will operate over a much narrower dc voltage range (1.3:1 maximum to minimum dc voltage ratio compared to the $40-\mathrm{kW}$ ratio of nearly $2: 1)$. Elimination of the dc/dc converter stage decreases cost and improves reliability and performance.

The individual commutation circuit was tested in a one-quarter scale powerpole to confirm its feasibility for the on-site inverter. The 1983 NASA On-Site effort in this subtask then became one of providing a detailed on-site inverter system electrical design using identified technologies from tradeoff and optimization studies which, with mechanical design support from a parallel GRI program, would provide Subtask 3.2 with the necessary information for procuring brassboard inverter hardware.

System Definition - Other on-site program activity established a rating of $200 \mathrm{~kW}$ for the development inverter, defined the system as grid-connected only, provided an estimate of the fuel cell dc operating characteristics, and defined the ac utility line interface voltage. From this governing set of criteria an inverter system definition was established, as depicted in Figure 3.1-1. The primary elements are: 


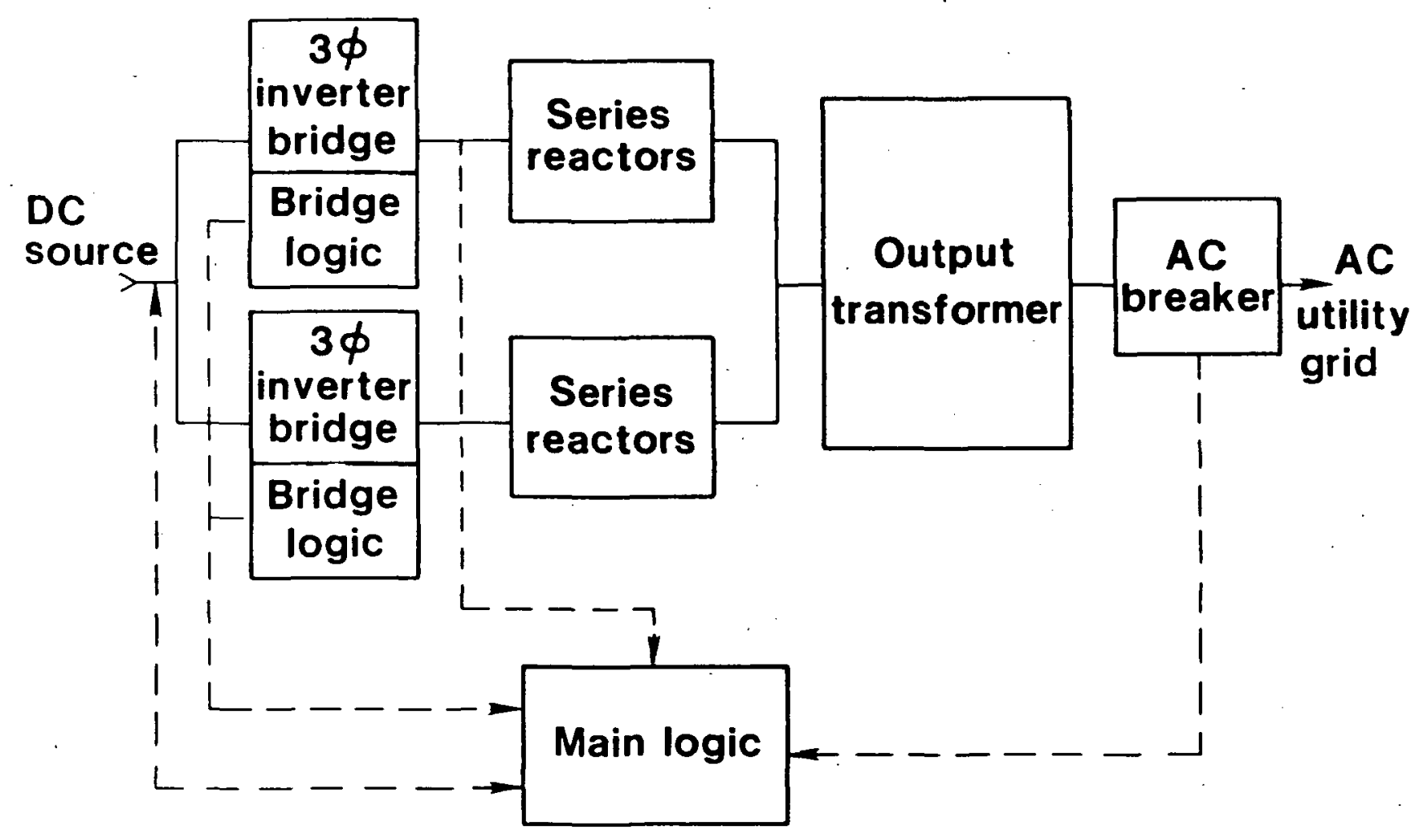

Figure 3.1-1. 200-kW Inverter. System 
- Two three-phase inverter bridges utilizing pulse width modulation for control of fundamental and harmonic voltages (the two bridges operate $30^{\circ}$ displaced into a delta-wye transformer to magnetically eliminate the 5 th/7th harmonics and their conjugate pairs).

- Series reactors which provide the bulk of the system's $22 \%$ impedance for the controls to work against and which provide a buffer between the bridges and the utility line.

- A full isolation two-winding power transformer that provides a voltage match between the bridge outputs and the utility line, as well as grounding isolation.

- The control and protection logic, which provides all necessary operating, regulating, and protective functions for automatic, unattended operation. The logic is comprised of two parts, bridge logic and main logic, of which the bridge logic was defined in detail in this year's program (see Subtask 3.2).

Initial efforts concentrated on three areas:

- Definition of electrical components.

- Selection of the most appropriate semiconductor for the electrical circuit operating requirements, and

- Identification of the least costly and/or most efficient circuits to meet the on-site inverter requirements.

Analyses and studies in these three closely interrelated areas were performed simultaneously, with proper visibility to insure compatible results. 
Component Definition - An electrical circuit schematic for the bridges, series reactors, and output transformer was detailed by defining the specific component values necessary to meet the on-site performance requirements.

That configuration was then reviewed to insure functionality, with proper safety margins and optimization of components to achieve maximum performance. Minor component modifications were made in this step. The end result was an on-site inverter operating over a dc input voltage range of 190 to $260 \mathrm{~V} \mathrm{dc}$, delivering 200 $\mathrm{kW}$ at $1.0+.05$ power factor into a nominal $480 \mathrm{~V}$ ac, three-phase utility line with a calculated efficiency of $93.6 \%$ at full load. Table $3.1-1$ shows the breakdown of losses and overall efficiency at full load, half load, and quarter load.

TABLE 3.1-1. CALCULATED INVERTER EFFICIENCY

\begin{tabular}{lccc}
\hline \hline & \multicolumn{3}{c}{ LOSS IN WATTS } \\
Subassembly & Full Load & Half Load & Quarter Load \\
\hline Input Filter & 200 & 230 & 260 \\
Switching Modules & 7,100 & 4,800 & 4,200 \\
Magnetics: & 4,700 & 2,100 & 1,450 \\
Logic and Controls & 300 & 300 & 300 \\
Miscellaneous & 1,400 & 1,070 & 890 \\
& 13,700 & 8,500 & 7,100 \\
Efficiency & $93.6 \%$ & $92.1 \%$ & $87.6 \%$ \\
\hline
\end{tabular}

* Assumes $2 \%$ losses in transformer and 700 watts in series reactors.

The lower part power efficiencies are due primarily to two items:

1. The magnetic losses are not linear with output power, due to the core loss portion. 
2. The switching module losses are not linear with output, due to commutation and switching occurring at higher voltages at part power.

Optimization Studies - The purpose of these studies was to find a way to improve inverter performance in three areas (output transformer, commutation circuit, and semiconductors) while maintaining a cost penalty for the improvement that would not penalize the overall power plant. Improving inverter efficiency, in effect, will allow the dc module to contain fewer cells and still achieve the same system performance. To be of benefit, however, this improvement must cost less than the savings attributed to using fewer cells.

Of the three areas, the first area studied was the output transformer. Typical commercial magnetics in this power range have full load 10 sses between $5 \%$ and $2 \%$ of rating. The baseline studies on efficiency had assumed $2 \%$, which is commonly referred to as $85^{\circ} \mathrm{C}$ rise design. Several manufacturers were queried as to the cost and weight penalties in designing a transformer for $1 \%$ loss at full load. Initial feedback was not promising, with little detail provided. One manufacturer did show an interest in analyzing this question, however, and provided the information shown in Figure 3.1-2. The manufacturer performed a design analysis and estimated that an output transformer with a $1 \%$ full load loss would weigh $27 \%$ more and cost $20 \%$ more than a $2 \%$ loss design. Since the $20 \%$ cost increase was much less costly than equivalent dc module cells, the $1 \%$ transformer was included in the brassboard system, and the full load inverter efficiency estimate increased to $94.6 \%$.

Another possibility for efficiency improvement was in the use of auxiliary commutation for surge circuitry (ACS). The baseline design incorporated one main commutation circuit sized to handle the energy required to commutate off the peak current necessary to handle surges at the minimum dc operating voltage. The ACS concept is to: 


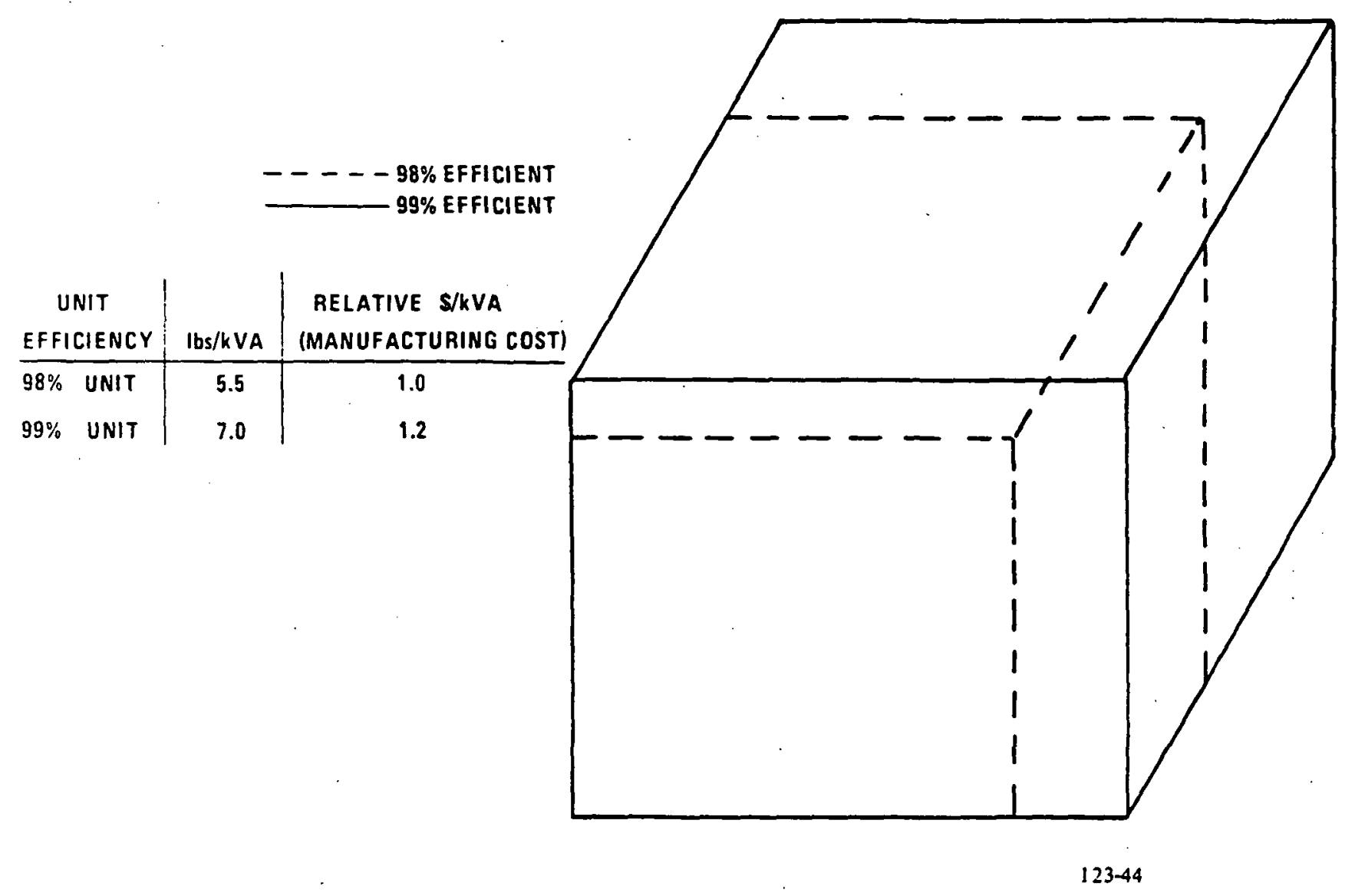

Figure 3.1-2. Output Transformer Outline 
1. Use a smaller main commutation circuit for normal full load current plus an approximate $30 \%$ margin to handle minor perturbations,

2. Use ACS whenever the current exceeds the $30 \%$ margin, to handle surges and faults.

This concept was investigated previously for MW-scale inverters. Evaluation of ACS designed for the $200-\mathrm{kW}$ brassboard inverter showed the results in Table 3.1-2.

TABLE 3.1-2. AUXILIARY COMMUTATION FOR SURGE EFFECT ON EFFICIENCY

\begin{tabular}{lcccc}
\hline \hline & \multicolumn{2}{c}{ Commutation } & Circuit Losses & (Watts) \\
Lithout & ACS & $\begin{array}{c}\text { With } \\
\text { ACS }\end{array}$ & Delta & $\begin{array}{c}\text { System } \\
\text { Inficiency } \\
\text { Increase (\%) }\end{array}$ \\
\hline Full Load & 828 & 462 & 366 & 0.2 \\
Half Load & 1,116 & 702 & 414 & 0.4 \\
Quarter Load & 1,884 & 1,452 & 432 & 1.0 \\
\hline \hline
\end{tabular}

The $0.2^{\circ}$ improvements at full load, when viewed as a function of the cost of the ACS on a system basis, resulted in a break-even situation. The ACS, however, was incorporated into the $200 \mathrm{~kW}$ brassboard design as a technology evaluation item and the inverter full load efficiency estimate increased to $94.8 \%$. ACS was considered an important concept that may be applicable in grid-independent inverter designs, to handle overload requirements without impacting normal rated load operation.

The third area analyzed utilized the results of the semiconductor device investigation. As discussed below, that investigation selected the asymmetrical SCR (ASCR) for the 200-kW brassboard inverter design (the inverter will be capable of operating with and evaluating other candidate devices, but the initial design/ construction will be with ASCR) and projected an improvement in the forward voltage drop from $1.7 \mathrm{~V}$ presently, to $1.3 \mathrm{~V}$ in the near future. Figure 3.1-3 shows the ef- 


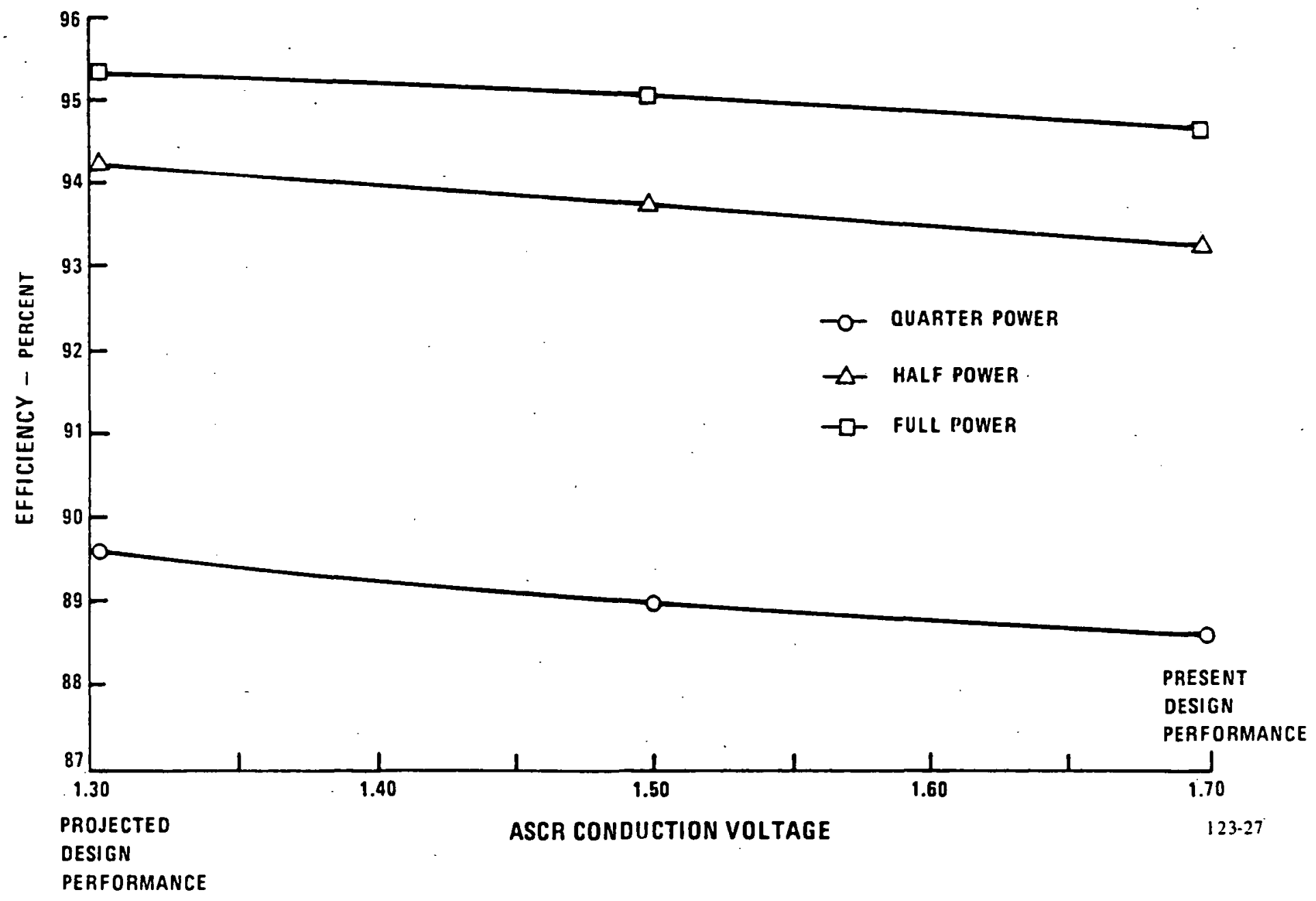

Figure 3.1-3. Inverter Efficiency vs. Projected ASCR Performance 
ficiency benefit derived from that ASCR performance increase to be about $0.6 \%$ at full load, bringing the brassboard estimated efficiency up to $95.4 \%$. In addition, the projection does not anticipate any cost increase associated with the better performing ASCR; it may even go down in cost.

Semiconductor Investigations - Semiconductor evaluation and forecasts were performed as on-going efforts in this On-Site task. The initial study effort looked at present (1983) SCR's, ASCR's, and GTO's versus near term projections (1985). The results are summarized in Table 3.1-3. Note that reverse conducting thyristors (RCT's) are not included, as they offer no advantage over the ASCR in performance and are more costly. From Table 3.1-3 it is not apparent that the brassboard current choice of a main thyristor would be the ASCR, as it is no better than the $\mathrm{SCR}$. As discussed above, the ASCR does project much better future performance in forward voltage drop, pulse loss, and cost, and for those reasons was selected to provide early insight into that technology.

Continuation of discussions and information gathering with and from semiconductor manufacturers has resulted in the following recent conclusions:

1. RCT's may warrant another look; their pricing structure may become more favorable.

2. GTO's (gate turn-off thyristors) are presently not optimally designed for this application. (They may yet be considered, however, as their use deletes the need for commutation circuitry.) To properly evaluate and understand GTO's and their use, engineering samples are being purchased for laboratory evaluation and possible testing in the brassboard inverter in a derated configuration for one-half or one powerpole.

This subtask also evaluated different methods for cooling the brassboard inverter bridges. Once the electrical circuit was defined and the semiconductors identified, estimated losses were calculated. The parallel GRI effort provided a mechanical packaging concept from which the cooling study could evolve, using the estimated 


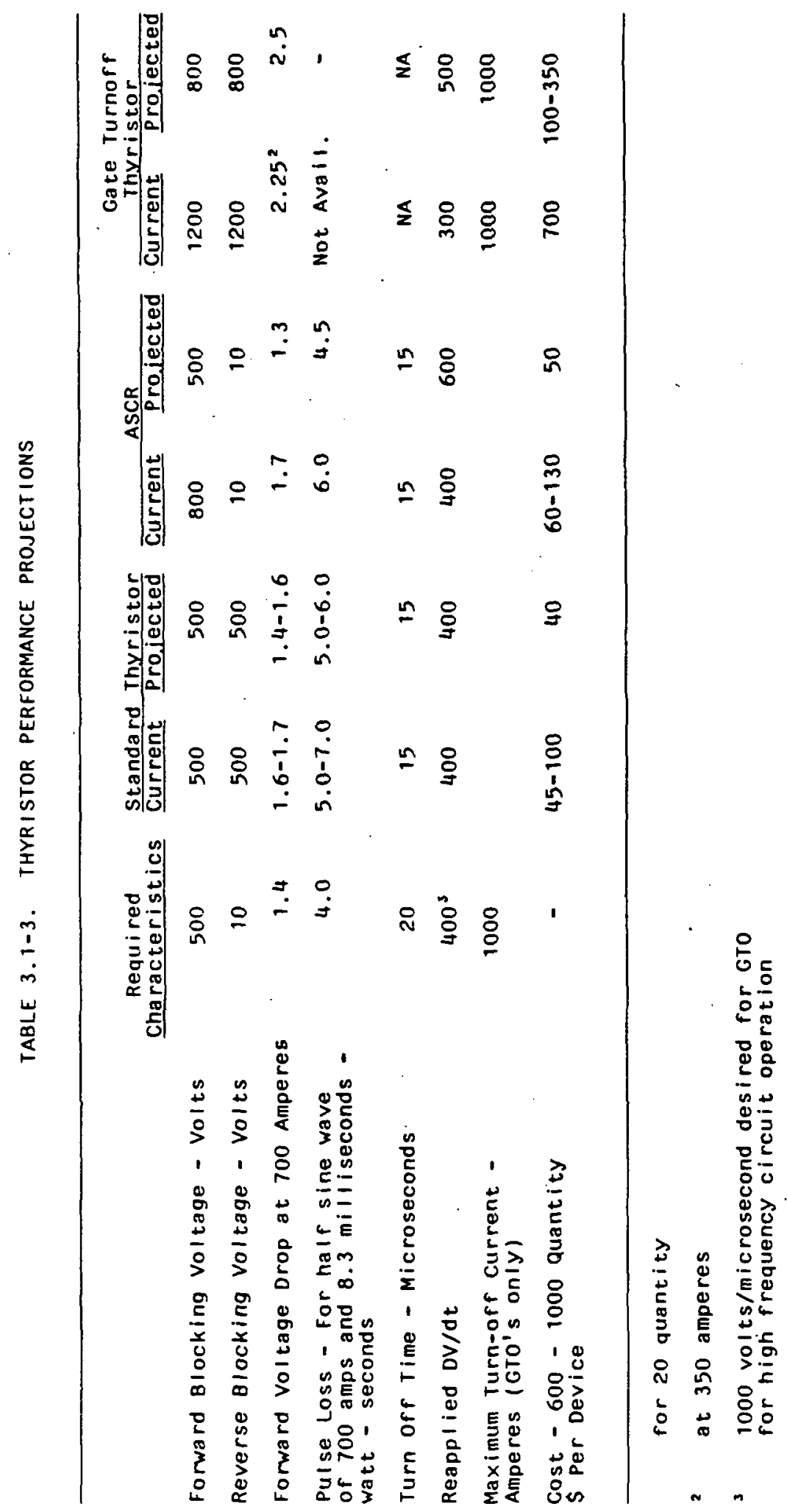


losses for the semiconductors and other components. The study included three types of cooling:

- Forced air

- Liquid

- Heat pipe

Table 3.1-4 shows results for the analysis of forced air cooling with extruded aluminum heat sinks. The maximum calculated semiconductor junction temperature is $109^{\circ} \mathrm{C}$, with $120^{\circ} \mathrm{F}$ ambient inlet cooling air. The acceptable junction temperature limit is $125^{\circ} \mathrm{C}$, with $115^{\circ} \mathrm{C}$ preferred for margin. A similar analysis for liquid cooling showed equivalent performance can be obtained, but at a much higher cost. Cost estimates based on parts requirements alone showed liquid cooling to be twice as costly. Also, previous studies and experience proved heat pipes to be cost effective at cooling loads significantly higher than those of the 200-kW inverter. The forced air/heat sink method was the logical choice to meet requirements at the minimum cost.

Preliminary results of the air cooling study are shown in Table 3.1-4. All selected leat sinks are either catalog items, or based on the $40-\mathrm{kW}$ design. These results show that, at an ambient temperature of $43^{\circ} \mathrm{C}$, all semiconductor junctions are maintained well below the $125^{\circ} \mathrm{C}$ maximum requirement, and that the cooling air temperature rise is about $7^{\circ} \mathrm{C}$ at a flow rate of 1560 cubic feet per minute. Blower and ducting design studies continue. 
TABLE 3.1-4. BRIDGE COOLING SUMMARY

\begin{tabular}{|c|c|c|c|c|}
\hline Item & $\begin{array}{l}\text { *Watts } \\
\text { Loss Each }\end{array}$ & $\begin{array}{l}\text { Qty. Per } \\
\text { Bridge }\end{array}$ & $\begin{array}{l}\text { CFM Air } \\
\text { Req'd Each }\end{array}$ & $\begin{array}{l}\text { Calculate } \\
\text { Junction } \\
\text { Temp. }{ }^{\circ} \mathrm{C}\end{array}$ \\
\hline Main Thyristor & 345 & 6 & 80 & $109^{\circ}$ \\
\hline Commutation Thyristor & 170 & 6 & 80 & $108.7^{\circ}$ \\
\hline Main Diode & 100 & 6 & 30 & $92^{\circ}$ \\
\hline Commutation Diode & 75 & 6 & 30 & $91.5^{\circ}$ \\
\hline Clamp Diode & 75 & 6 & 40 & $107^{\circ}$ \\
\hline \multicolumn{2}{|c|}{$\begin{array}{l}\text { Heat Load Due to Other Components } \\
\text { Total Air Flow Per Bridge } \\
\text { Max Inlet Air Temp } \\
\text { Max Exit Air Temp }\end{array}$} & \multicolumn{2}{|c|}{$\begin{array}{l}1410 \text { Watts } \\
1560 \mathrm{CFM} \\
43.3^{\circ} \mathrm{C} \\
50.7^{\circ} \mathrm{C}\end{array}$} & \\
\hline
\end{tabular}

$\therefore$ All semiconductor "worst case" losses do not occur simultaneously. Losses cannot be directly added to get total for pole.

The output of this effort was incorporated in the Subtask 3.2 activity, which procures the low cost, high efficiency brassboard inverter. The semiconductor investigation selected ASCR's for the brassboard inverter and has selected experimental GTO's to be purchased for laboratory evaluation and possible future operation in the brassboard inverter.

The 1984 effort in this subtask will:

1. Continue projections for advanced semiconductors to identify brassboard test candidates,

2. Provide a preliminary design definition for the brassboard main logic to allow line parallel operation. 


\section{Subtask 3.2 Verify Inverter Technology}

\section{Objective}

The objective of this subtask was to construct a 200-kW brassboard inverter configured to facilitate evaluation of alternative semiconductors, incorporating the results of Subtask 3.1 .

\section{Summary}

The beneficial technology, cost, and efficiency elements identified in Subtask 3.1 were incorporated into a detailed electrical bridge design for a $200-\mathrm{kW}$ brassboard inverter. A subcontract was placed with a commercial electrical/electronics equipment manufacturer who provided a mechanical design (funded by GRI) and constructed two bridges and the series reactors for the $200-\mathrm{kW}$ brassboard inverter. The brassboard inverter bridge logic, which was conceptually identified and based on distributed microprocessor technology under an earlier GRI study, was carried from the conceptual design to a detailed hardware and software design. A bridge logic vendor was selected to perform a six-phase subcontract effort, which culminates in delivery of two sets of brassboard bridge, logic, one for each of two brassboard bridges. A vendor procurement for a low loss output transformer has also been established. The bridges and output transformer are scheduled for delivery to UTC in late December 1983, and the bridge logic is due in January of 1984.

\section{$\underline{\text { Highlights }}$}

- Completed brassboard bridge logic hardware and software design and started laboratory refinement.

- Specified all brassboard inverter bridge electrical components, sensors, control/protection interfaces, series reactors, and output transformer for procurement.

- Placed a subcontract for the brassboard bridges and series reactors, with delivery scheduled for December 1983. 
$\circ$ Placed a subcontract for bridge control units, with delivery scheduled for January 1984 .

- Delivery of an output transformer with $99 \%$ full load efficiency scheduled for December 1983.

\section{$\underline{\text { Discussion }}$}

Beneficial results identified in Subtask 3.1 were incorporated into the brassboard inverter electrical design. Under this subtask, key subassembly and component procurement packages were defined and assembled to provide for hardware construction and delivery subcontracts.

A subcontract for the two bridges for the $200-\mathrm{kW}$ brassboard inverter was established with NASA and GRI supporting different portions of it, as shown below:

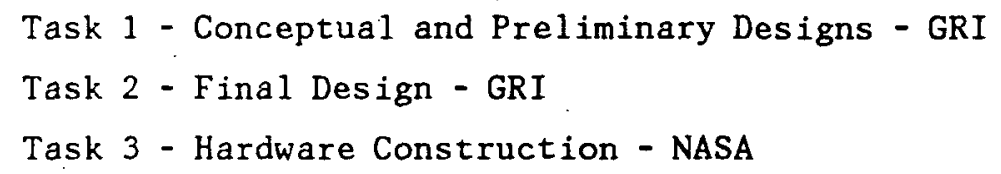

The vendor is responsible for the design and assembly/delivery of the two bridges. He supplies all the materials and components except the thyristors and commutation capacitors, which have been supplied to him by UTC. The semiconductors (main) and commutation thyristors were purchased with specified performance test results, to allow proper evaluation of their performance in the brassboard inverter.

The vendor has completed Tasks 1 and 2 of the subcontract and is in the process of the Task 3 hardware assembly effort. Delivery is scheduled for late December 1983. A full-scale mockup of one-half of a powerpole for these bridges is shown in Figure 3.2-1. This mockup simplified his explanation of the design, and was used for ful1scale cooling tests (results shown in Table 3.2-1) and to evaluate and measure the design's conformity to critical low inductance paths between specified components. 
Table 3.2-1. Brassboard Inverter Half Pole Thermal Test Results

\begin{tabular}{c|c|c|c|c|}
\multirow{2}{*}{ Test point } & \multicolumn{2}{|c|}{$\begin{array}{c}\text { Heat loads } \\
\text { (Watts) }\end{array}$} & \multicolumn{2}{|c|}{ Tase $^{*}\left({ }^{\circ} \mathrm{C}\right.$ ) } \\
\cline { 2 - 5 } & Measured & Spec & Measured & Spec \\
\hline Q1 & 370 & 380 & 69.5 & 90 \\
Q3 & 170 & 165 & 64.8 & 75 \\
D3 & 135 & 125 & 78.6 & 90 \\
D1 & 135 & 125 & 78.6 & 90 \\
D5 & 70 & 75 & 81.9 & 90 \\
D7 & 50 & $<50$ & 63.1 & 90 \\
Q5 & 30 & 30 & 60.6 & 90 \\
Inlet air (plenum) & - & - & $51.6 * *$ & - \\
Exhaust air & - & - & 54.4 & -
\end{tabular}

*Extrapolated to $\mathrm{T}_{\mathrm{a}}=49^{\circ} \mathrm{C}\left(120^{\circ} \mathrm{F}\right)$

**Series reactor heat loss simulated 
ORIGINAL PAGE IS OF POOR QUALITY

\section{Bridge Vendor - One Half Powerpole Mockup}

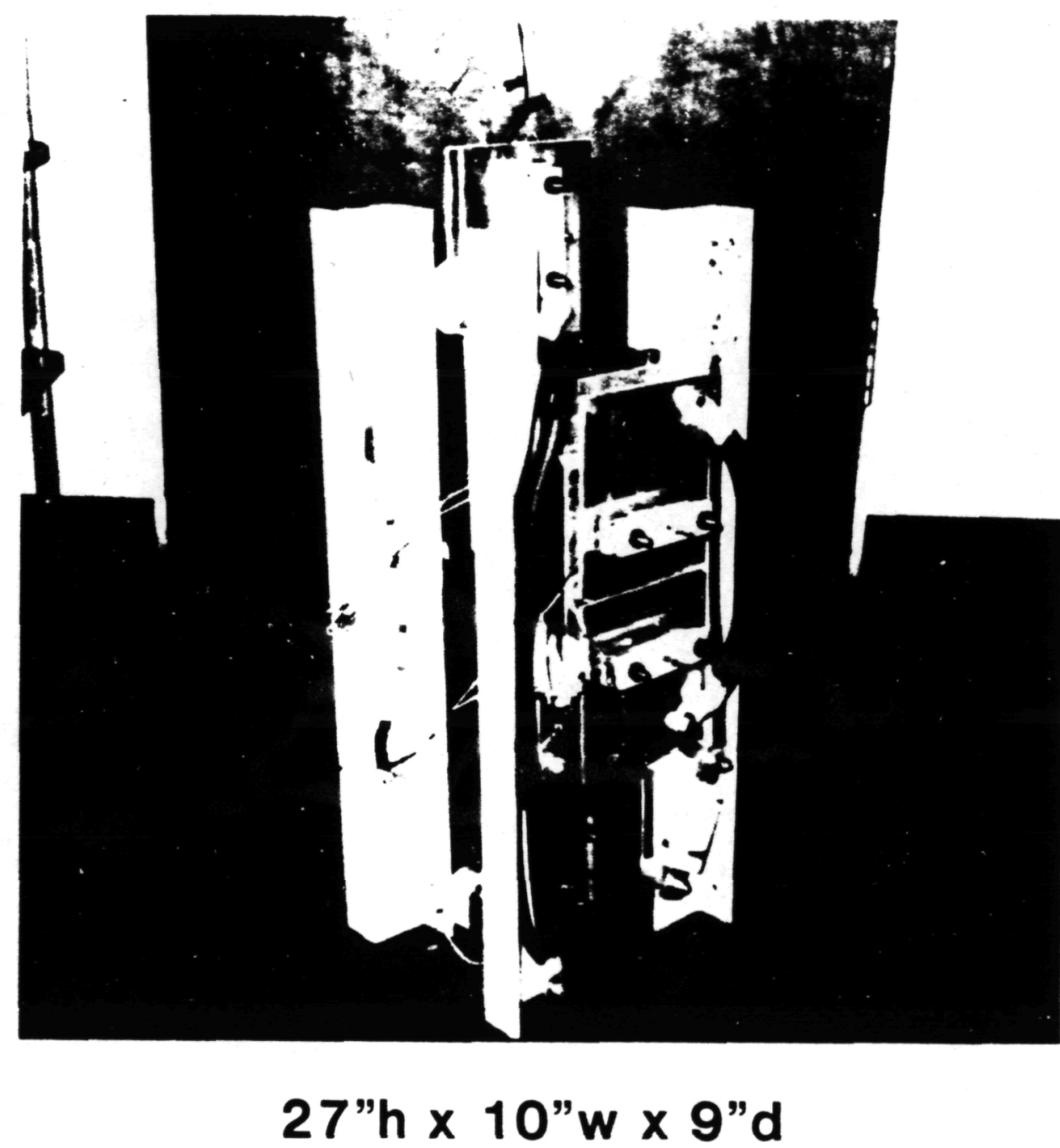

Figure 3.2-1. On-Site Brassboard Inverter One Half Power Pole Mockup 
Performance specifications for the $200-\mathrm{kW}$ brassboard inverter series reactors and output transformer were determined and assembled into component specifications for vendor design and fabrication. The series reactors are single-phase, iron core (six units required for the brassboard system), with open construction for natural convection cooling. They are specified as shown in Table 3.2-2.

TABLE 3.2-2. SERIES REACTORS SPECIFICATION

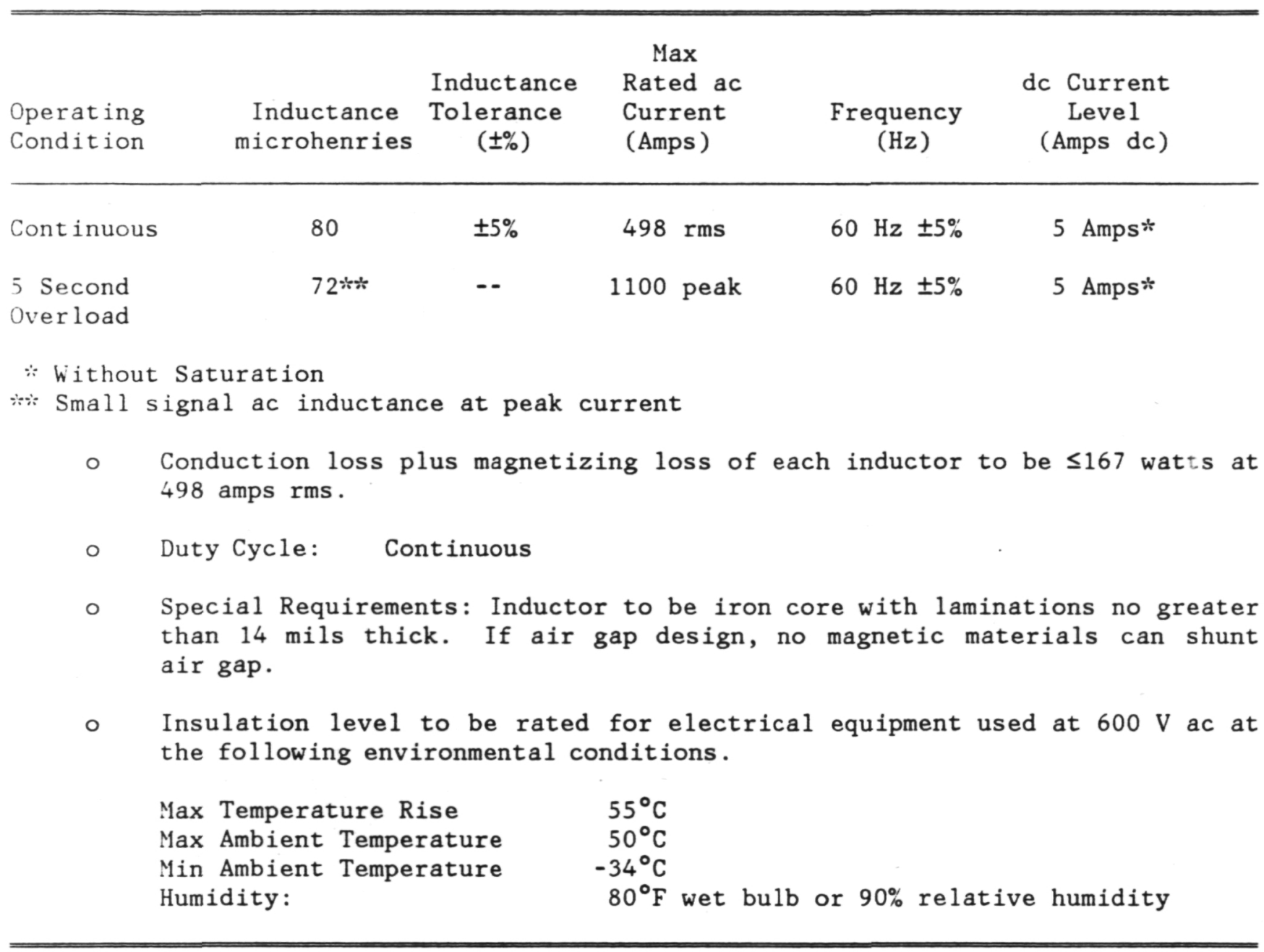

For the brassboard inverter, the series reactors are included in the bridge vendor subcontract. 
The output transformer is a three winding, delta-wye primary to wye secondary, full isolation power transformer. Requirements are as follows:

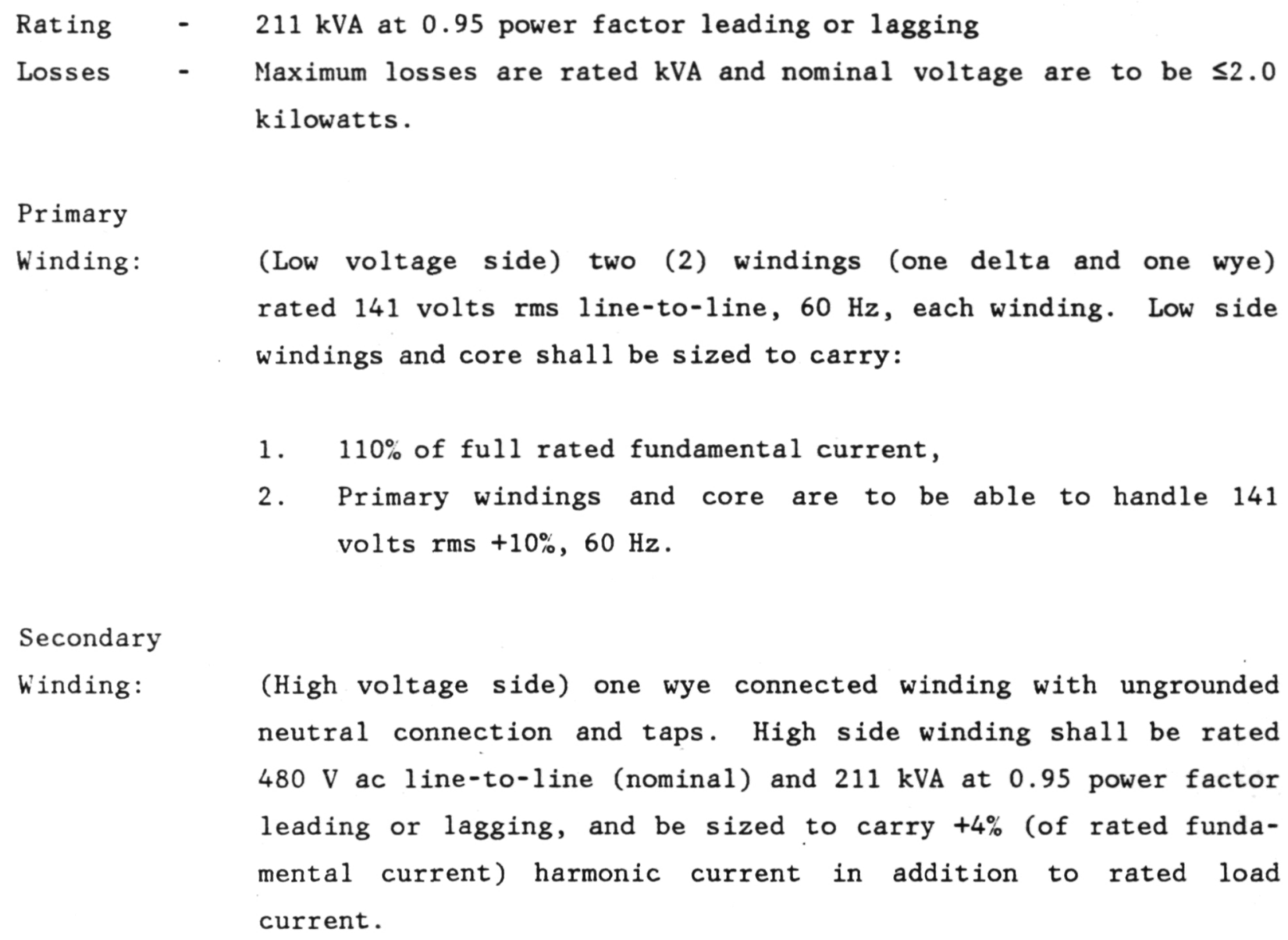

DC Unbalance: The primary side of the transformer shall be capable of withstanding up to 11 amperes dc net unbalance per wye leg.

Delivery of the output transformer is scheduled for December 1983.

The other major effort in this subtask is the design and procurement of bridge control and protection units. 
Earlier efforts under the 1982 GRI Program established a conceptual design for the logic to control and protect the inverter bridges (shown in Figure 3.2-2). The conceptual designs presented this logic as a single custom card. However, a three circuit board configuration consisting of two special cards and one standard computer card was selected for the brassboard hardware. This configuration was identified previously in work done as part of the Program to Develop Advanced Converter Technology for Battery Applications (DOE Contract DE-AC01-79ET29079). The three-board configuration is necessary in that program to handle the more sophisticated operating and interface requirements of a multi-megawatt power conditioner.

Use of this three-board concept for the brassboard will segregate functions to allow design evaluation and provide necessary flexibility where design changes and circuit modifications are needed due to new logic control design. Test results will be used to define a single-board configuration, estimated to be the least costly design for on-site application. Therefore, the logic vendor will also be responsible for single-board design review to ensure that bridge logic requirements are satisfied.

The bridge logic conceptual design was modified to meet brassboard inverter requirements. Detailed hardware and software designs were established, along with designs for sensing interfaces, to allow the logic to communicate with the bridges.

Once the hardware designs were complete, wirewrap circuit boards were constructed to aid in the hardware and software development efforts. Figure 3.2-3 shows a photo of the wirewrap waveform processor board, and Table 3.2-3 shows the status of the overall bridge logic development activity at UTC.

A subcontract, jointly funded by GRI and NASA, has been established to translate UTC designs and requirements into a packaged hardware design and to construct two sets of bridge logic, one for each of the $200-\mathrm{kW}$ brassboard bridges.

Task 1 Vendor Electrical Design Review - NASA

Task 2 Vendor Mechanical Design Review - NASA

Task 3 Vendor Testability/Maintainability Study - NASA 


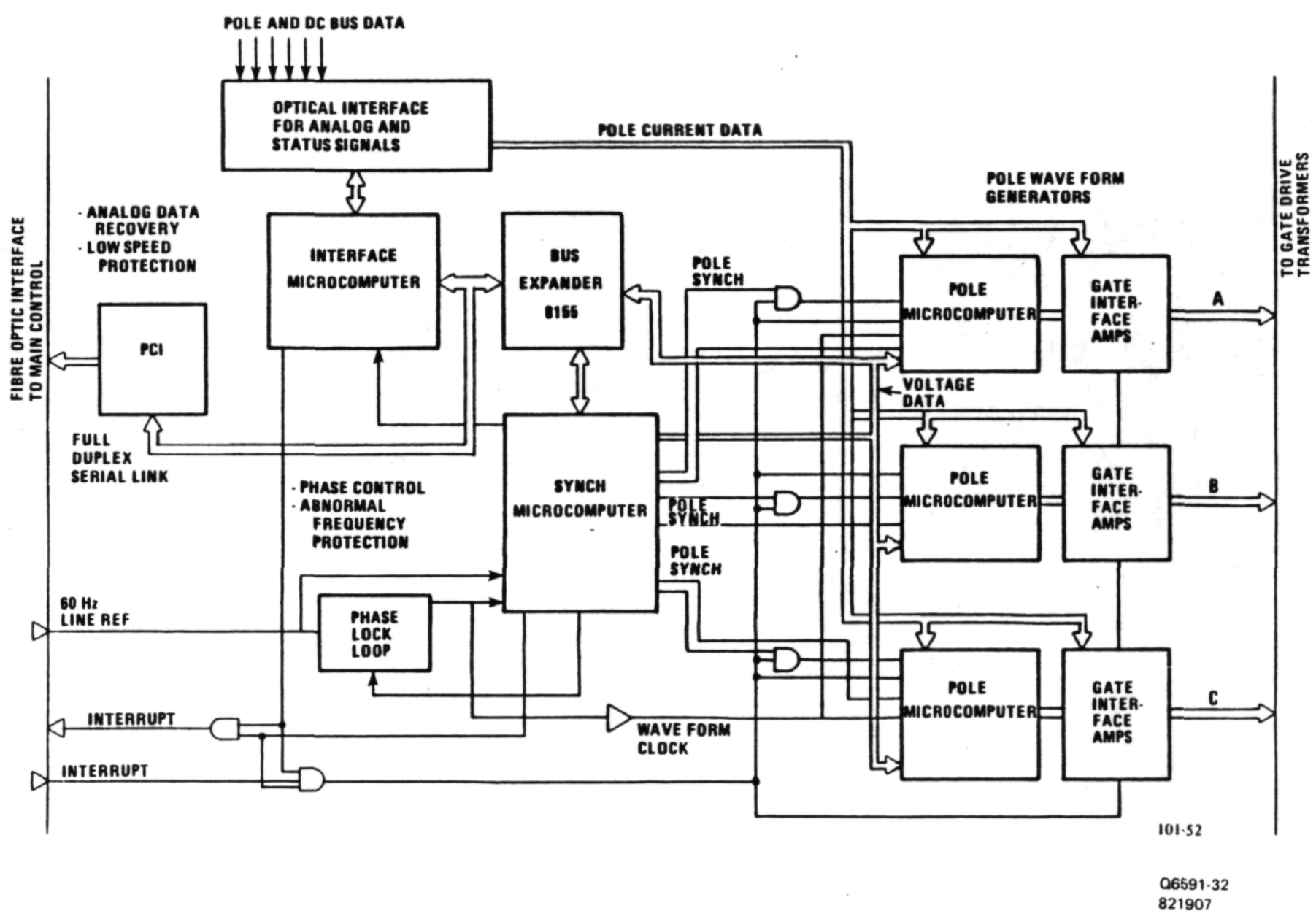

Figure 3.2-2. Schematic of Bridge Logic Control 


\section{ORIGINAL PAGE IS \\ OF POOR QUALTY}

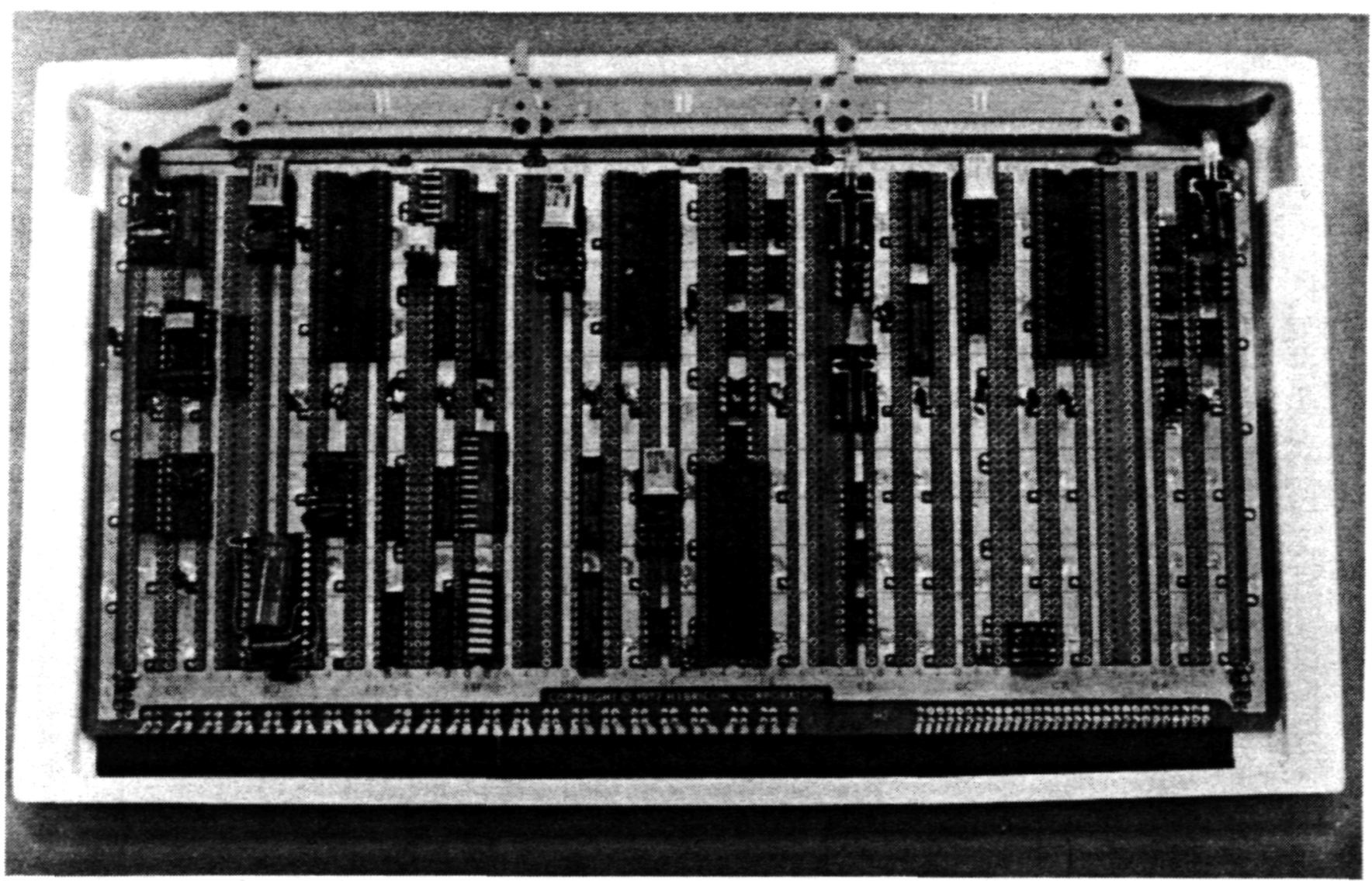

WCN-10614

Figure 3.2-3. Wirewrap Waveform Processor Board 
Table 3.2-3. Bridge Logic Status Summary

\begin{tabular}{|c|c|c|c|c|c|}
\hline $\begin{aligned} C & = \\
N A & = \\
N D & =\end{aligned}$ & $\begin{array}{l}\text { COMPLETED } \\
\text { NOT APPLICABLE } \\
\text { NOT DONE }\end{array}$ & 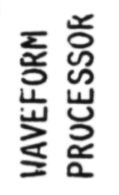 & 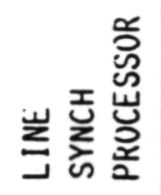 & 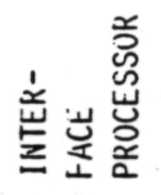 & 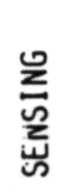 \\
\hline HARDWARE & $\begin{array}{l}\text { DETAILED REQUIREMENTS } \\
\text { CIRCUIT DESIGN } \\
\text { BREADBOARD } \\
\text { TEST }\end{array}$ & $\begin{array}{l}c \\
c \\
c \\
c\end{array}$ & $\begin{array}{c}C \\
C \\
C \\
N D\end{array}$ & $\begin{array}{l}\text { C } \\
N A \\
N A \\
\text { NA }\end{array}$ & $\begin{array}{c}C \\
C \\
C \\
N D\end{array}$ \\
\hline SOFTWARE & $\begin{array}{l}\text { DESIGN } \\
\text { WRITE CODE } \\
\text { TEST CODE MODULES } \\
\text { LINK MODULES } \\
\end{array}$ & $\begin{array}{l}c \\
c \\
c \\
c\end{array}$ & $\begin{array}{l}c \\
c \\
c \\
c\end{array}$ & $\begin{array}{l}c \\
c \\
c \\
c\end{array}$ & $\begin{array}{l}\text { NA } \\
\text { NA } \\
\text { NA } \\
\text { NA } \\
\end{array}$ \\
\hline SYSTEMS & $\begin{array}{l}\text { DEBUG SUBSYSTEMS } \\
\text { UNTEGRAUION }\end{array}$ & $\begin{array}{l}N D- \\
N D=\end{array}$ & & & \\
\hline
\end{tabular}


Task 4 Vendor Mechanical Design - GRI

Task 5 Construction - NASA

Task 6 Vendor Low Cost Design - GRI

The bridge logic vendor effort began with a review of UTC's designs for compliance with commercial or user standard practices, making sure that the required processes could be performed at the specified speeds by a generic brand of hardware. This review is deemed important because subtleties in hardware specifications may result in a microprocessor overload.

The logic vendor has completed his Task 1 review described above and found no significant design problems or concerns. Some improvements were recommended. From there the vendor will perform a mechanical design and construct the hardware. In addition, the vendor will formulate an approach for rapid acceptance testing of this type of logic and perform a study to determine if the three card design can be reduced to a single card to reduce cost. The bridge logic for the brassboard inverter bridges is due to be delivered in January or February of 1984.

The 1984 effort in this subtask will:

o Test the brassboard system first as subassemblies and components and then as system operating in grid connect.

o Support the hardware test with analytical predictions from UTC computer programs.

- Complete final design and procure main logic, which functions with the bridge logic for system line parallel operation. 
TASK 4 - HEAT EXCHANGER DEVELOPNENT

\section{Objective}

The objective of this task is to define an acceptable low cost acid removal device for on-site power plant applications. Definition of the acid removal device shall be based upon system, technology, and cost assessments of the candidate configurations, and component testing to verify performance and function. Candidate configurations shall include heat exchangers constructed with corrosion resistant materials and direct contact water cooling.

\section{Highlights}

- Experimentally evaluated one heat exchanger and two direct contact water cooling approaches for acid removal on a $200-\mathrm{kW}$ scale.

- Preferred acid condenser device for the on-site power plant is modified commercial heat exchanger with Teflon ${ }^{\circledR}$ covered metal surfaces; cost is $20 \%$ of the baseline $40-\mathrm{kW}$ unit on a $\$ / \mathrm{kW}$ basis.

- Evaporative spray cooling and contact saturation meet performance requirements and project to lower cost, but add to system complexity.

\section{Summary}

Direct contact water cooling systems and heat exchangers constructed of corrosion resistant materials were evaluated on their ability to remove acid from the cathode exhaust stream. Three candidate direct contact water cooling methods for acid removal were identified: contact condenser, evaporative water spray, and contact saturator. Contact condensing was eliminated, due to the cost impact on the water treatment system. Evaporative water spray cooling and contact saturation were selected for experimental evaluation. 
A $200-\mathrm{kW}$ size evaporative spray cooler rig was sized and fabricated. Testing with various packed bed materials resulted in identification of a stainless steel wire mesh packing that gave acceptable performance; an acceptable water flow control system has not yet been defined.

A contact saturator, operating at a constant water flow rate, was sized for a 200-kW system. A test rig was assembled, and testing demonstrated feasibility of this concept for acid removal.

Two heat exchangers made of corrosion resistant Teflon and one design in graphite were analyzed for acid condenser application. The unit determined most suitable for on-site application is a modified vendor design that uses Tefion covered metal tubes and a Teflon lined enclosure. A prototype for a 200-kW system was procured and component testing showed design point performance to meet requirements. The projected cost is approximately $20 \%$ of the cost $(\$ / \mathrm{kW})$ of the baseline $40-\mathrm{kW}$ acid condenser.

\section{Discussion}

Development activity in this area includes evaluation of two methods of removing acid from the cathode exhaust stream. One approach is to use heat exchangers made of materials resistant to the corroding effects of phosphoric acid. The other approach is to use a form of direct contact water cooling, which would reduce the gas stream temperature and condense the acid.

Program History - Work was conducted under the GRI On-Site Technology Development Program to identify corrosion resistant heat exchangers able to meet requirements of the cathode exhaust acid condenser. In addition, limited work was conducted to evaluate evaporative spray cooling as a means of condensing the acid.

Three candidate heat exchangers fabricated from corrosion resistant materials and sized for a $300-\mathrm{kW}$ power plant were identified in vendor surveys conducted during 
the GRI Phase I and II programs. These are summarized below, along with planned follow-up activity.

- One of the candidates was a graphite-constructed unit. This unit met functional requirements but was expensive and large. No further activity is planned with this approach.

- The second candidate was a shell and tube configuration that incorporated Teflon tubes. In this unit the corrosive cathode stream flows through the tube side. However, due to the small diameter of the Teflon tubes, the pressure drop is above specifications. Since units of larger shell or tube diameters are not available, desired pressure drop cannot be achieved. The feasibility of placing the exhaust stream on the shell side was investigated in this program. Units with Teflon lined shells can be provided for this reverse stream situation.

- The third candidate was a configuration that featured Teflon covered metal tubes and a Teflon lined enclosure. This offering had a reasonable cost estimate, but did not meet all functional requirements. Discussions revealed that the changes necessary to meet on-site requirements would be within vendor capabilities, and activity to develop this configuration is considered worthwhile.

Heat Exchanger Development - The objective of the heat exchanger development effort is to define a more functional and less costly design than that presently used in the $40-\mathrm{kW}$ power plant. Work conducted in this phase of the program included the assessment of corrosion resistant heat exchangers identified in the GRI program. A discussion of this effort follows.

Candidate A - Investigation continued on the shell and tube heat exchanger that uses Teflon tubes. The original configuration, which had the exhaust stream on the tube side, exceeded pressure drop allocation. Placing the exhaust stream on the shell side, to reduce pressure drop, results in an excessiveiy costly unit. This prompted 
investigation of alternatives, specifically, using one of the vendor's standard Teflon tube bundles and enclosing it in a Teflon lined, box-type enclosure. This approach provides flexibility in selection of a tube bundle to meet heat transfer requirements and allows the cathode stream to be conveniently placed on the enclosure (shell) side to achieve low pressure drop. A performance sizing study has shown that the smallest Teflon tube bundle that meets 200-kW performance requirements and the Teflon lined enclosure for this tube bundle are no less costly than other approaches. The Teflon tube bundle vendor is unable to provide the type of enclosure required and would have to subcontract this work. No further activity is planned with this less-developed approach, since there is no cost advantage (relative to the other candidate heat exchanger), and additional effort would be required to design and procure an enclosure.

Candidate B - The acid condenser heat exchanger with Teflon covered tubes and a Teflon lined shell was also evaluated. The vendor supplied a unit sized for a $300-\mathrm{kW}$ system that did not fully meet requirements, since he took exception to power plant condensate water conditions and assumed $80^{\circ} \mathrm{F}$ customer water on the tube side. The tubes in this heat exchanger were made of copper, which would be affected by the carbonic acid in the condensate water. The vendor confirmed that stainless steel tubes, which provide the required corrosion resistance, could be substituted for the copper tubes. The heat exchanger was resized to meet $200-\mathrm{kW}$ power plant requirements. It was determined that a core approximately $70 \%$ larger than initially offered would be required to meet $200-\mathrm{kW}$ requirements. The larger core, in conjunction with stainless steel tubes, resulted in an unacceptably high cost.

The vendor then offered core designs with tighter tube spacing and smaller frontal areas in the direction of gas flow. This allowed for better utilization of the pressure drop allocation, which had been increased by $50 \%$ as a result of system optimization studies. A study was conducted to define a smaller, more effective core based on the new design alternatives, which resulted in a core approximately 10 inches wide by 24 inches high by 20 inches long. This is about one-third the size of the initial $200-\mathrm{kW}$ heat exchanger. 
Figure 4-1 shows the latest acid condenser heat exchanger design. The unit does not include gas side manifolds, which are required for power plant operation.

The vendor prepared a design for a 200-kW acid condenser heat exchanger. After review and approval, a prototype unit was procured for performance testing (Figure 4-2). A separator, required for removing residual acid mist from the exit stream in power plant operation, was designed and fabricated. The acid separator is similar to the $40 \mathrm{~kW}$ design that utilizes graphite substrate elements. Although testing was conducted with an acid-free stream, the separator was included to insure pressure drop values were representative of power plant operation.

The heat exchanger was instrumented and installed in a test stand to evaluate performance and operational characteristics. Testing was conducted without acid vapor in the hot gas inlet stream, due to the difficulty in producing an acid-laden stream without a cell stack. Verification of the heat exchanger's ability to condense acid was based on achieving an exit temperature of about $265^{\circ} \mathrm{F}$ or lower. Experience with $40-\mathrm{kW}$ power plants shows this to be a valid standard.

A summary of the test results is shown in Table 4-1. Testing at the 200-kW design point showed that all performance requirements were met. The maximum local gas stream temperature at the exit of the core was about $260^{\circ} \mathrm{F}$. Total pressure drop for the heat exchanger and acid separator was about $1^{\prime \prime} \mathrm{H}_{2} \mathrm{O}$, which is well within the allocated level. No water side flow instability was observed. System heat and water balances were generally within $5 \%$, which supported test data. A small amount of water leakage was observed at the tube joints during testing, which the vendor attributed to the type of stainless steel tubing used. The problem will be corrected by retrofitting the unit with higher quality tubing. The amount of leakage is minor and does not affect test results.

Testing at a low power operating point ( $30 \mathrm{~kW})$ showed that the heat exchanger will overperform when the condensate water is in the $70-120^{\circ} \mathrm{F}$ range. This situation produced local gas stream exit temperatures that were below the dew point, causing water condensation. A solution to this problem would be to preheat the condensate 


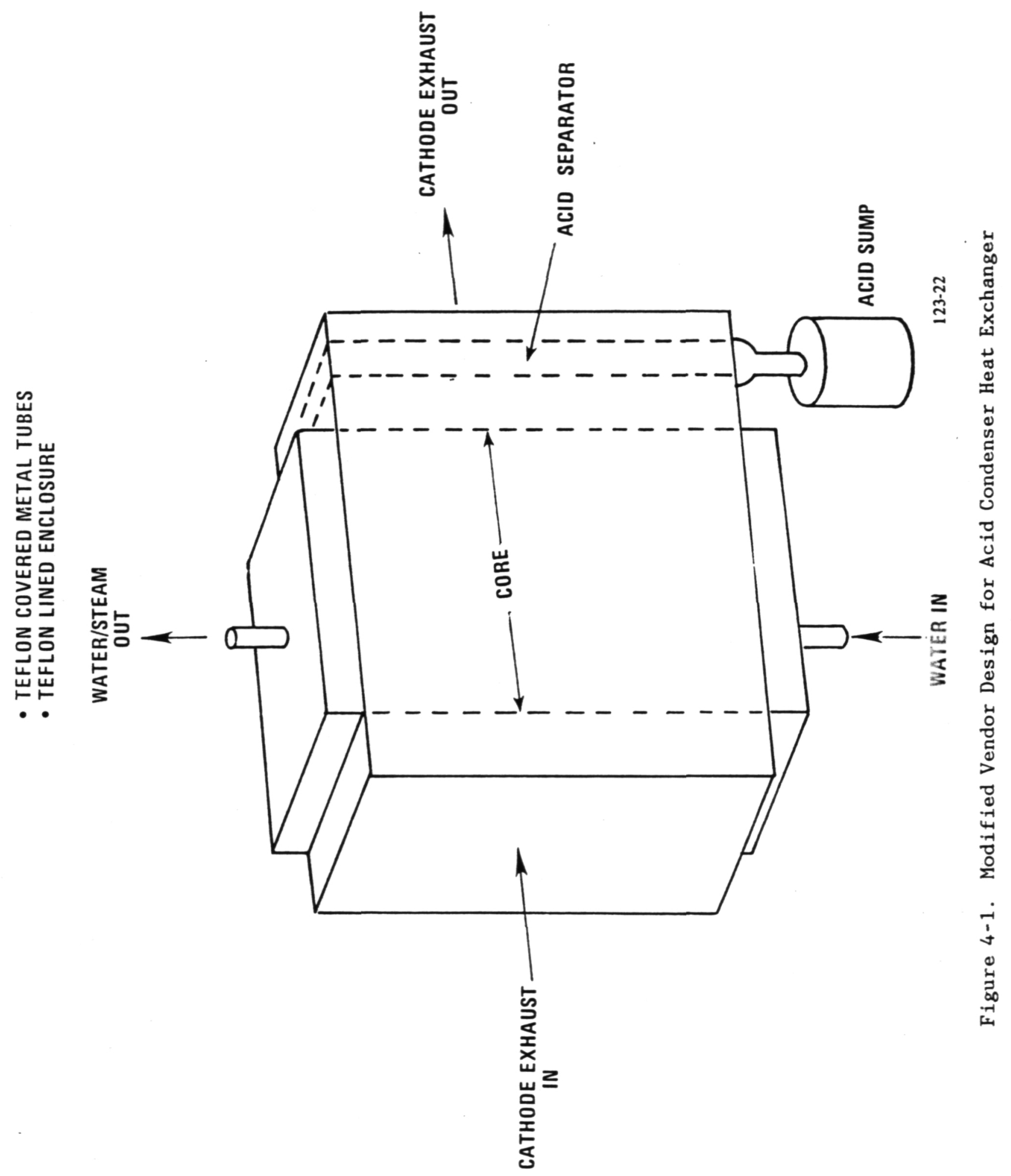




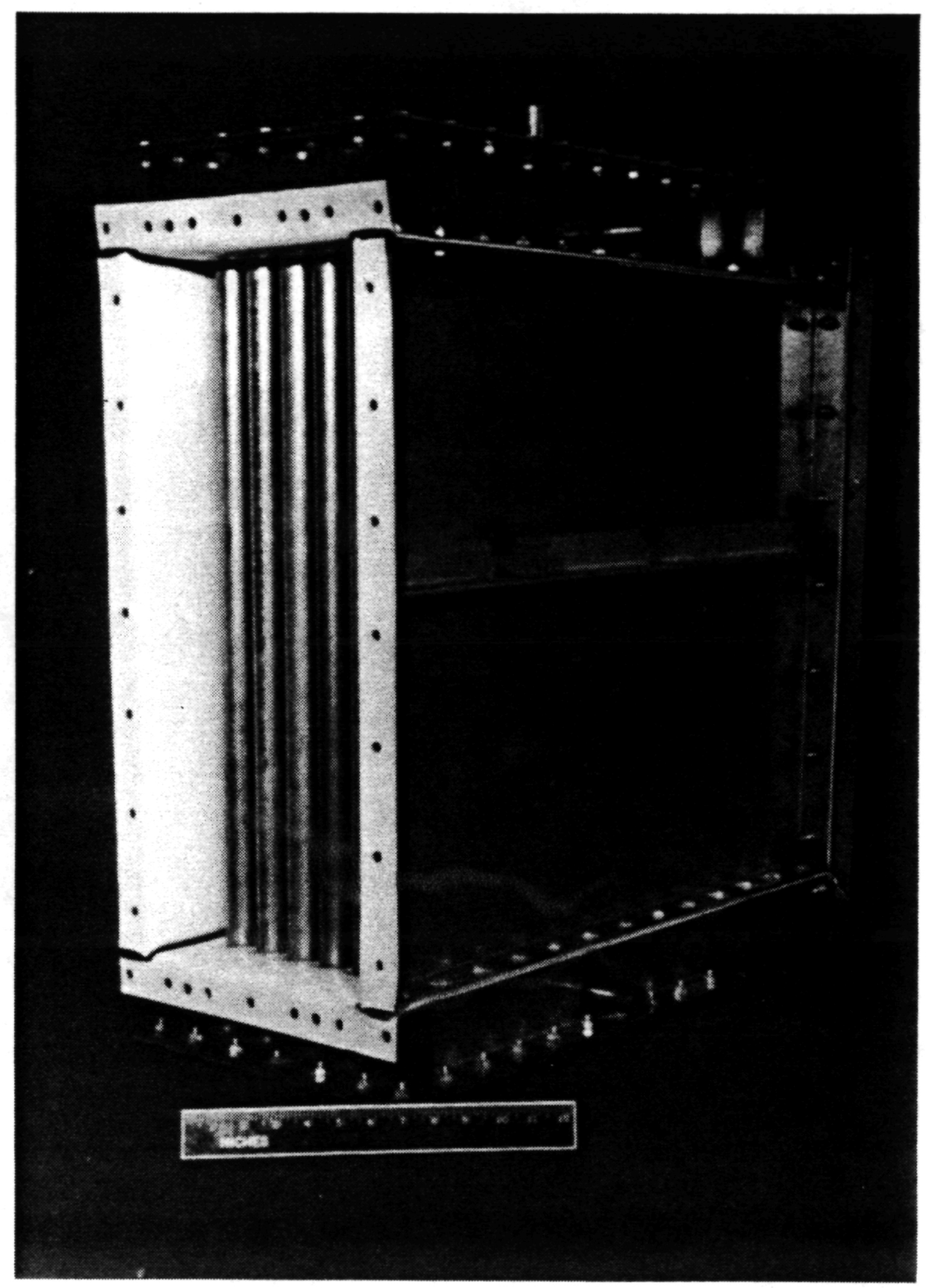

WCN-10710

Figure 4-2. Prototype 200-kW Acid Condenser Heat Exchanger 
water to a temperature near the gas stream dew point, a convenient heat source being the $212^{\circ} \mathrm{F}$ exit water. There were no functional problems with the heat exchanger at the low power operating point.

With modifications to correct water leakage and low power overperformance, this heat exchanger is considered an acceptable acid removal device for the on-site power plant. The cost of this heat exchanger is slightly higher than direct contact water cooling approaches; however, its life, reliability, control free operation, and favorable system impact compensate for this.

Performance testing has shown that potential for further cost reduction does exist with this heat exchanger. "A reduction in core size may be possible by incorporating multipass flow on the water side or the gas side, and these configuration changes could be incorporated by the vendor. The cost reduction potential of these changes will be investigated in a future program.

TABLE 4-1. ACID CONDENSER HEAT EXCHANGER TEST RESULTS

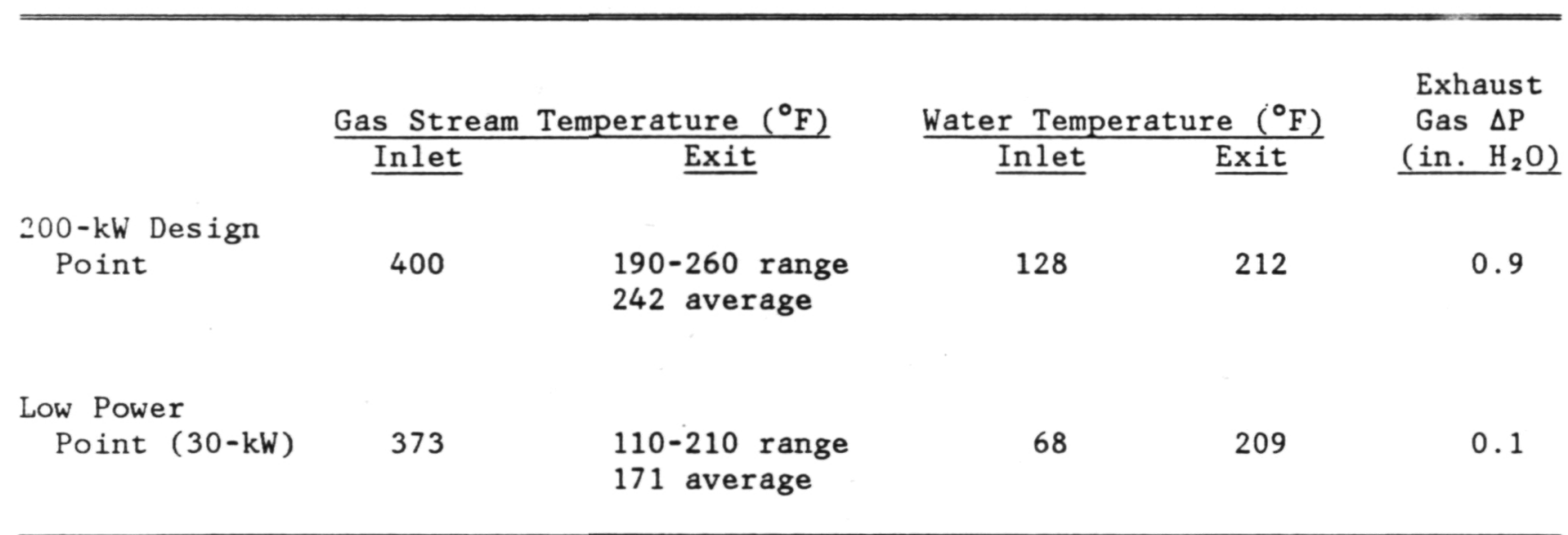


Direct Contact Water Cooling - Efforts were made to develop an alternative approach to the acid condenser heat exchanger. Various types of direct contact water cooling were considered, including evaporative spray cooling, contact saturation, and contact condensing.

The mechanism involved in these acid removal concepts is the evaporation of a water spray by direct contact with the cathode exhaust stream. In the case of the evaporative cooler, a controlled amount of water is injected into the cathode exhaust stream, cooling it to the desired acid condensing temperature of approximately $265^{\circ} \mathrm{F}$. In the contact saturator and the contact condensor, acid is essentially washed out of the cathode exhaust stream by the injected water. In the latter concept both acid and water vapor in the cathode stream are condensed and removed.

A systems assessment was performed, and it was determined that all three candidate methods could be incorporated into an on-site power plant.

The impact of contact condensing on the water treatment system was determined. Based on the estimated acid loss rate, the load on the water treatment system would increase by a factor of about five, which increases the cost of the demineralizer by a like factor for equivalent bed life. Since this cost penalty is unacceptably high, no further activity is planned using this approach. Based on system and cost assessments, evaporative spray cooling and contact saturation were selected for experimental evaluation.

Evaporative Water Spray Cooling - Candidate nozzles were tested to determine spray pattern and turndown capability for evaporative spray cooling application. Steam assist water spray nozzles were selected for initial testing; these use steam energy to atomize the water. These nozzles have a larger orifice for a given flow rate than conventional nozzles and can be operated over a larger turndown. Bench testing was conducted and a selection was made for the full-scale evaporative spray cooler rig. The nozzle selected did not produce complete atomization at the $200-\mathrm{kW}$ flow rate, but the downstream packed bed in the evaporative spray cooler should compen- 
sate for this. Spray quality of the nozzle improved at lower flow rates, which means turndown should not be a problem.

The selected water source for evaporative spray cooling is power plant feedwater taken from the exit of the demineralizer. This is the cleanest water available and should minimize the possibility of nozzle plugging. For nozzle and rig testing, facility DI/DO water was used, since it closely resembles power plant feedwater.

A vessel and packed bed were fabricated to meet the requirements of the evaporative spray cooler. A schematic sketch of the test rig is shown in Figure 4-3. Figure 4-4 shows the test rig prior to installation in the test stand. The test results are discussed below and summarized in Table 4-2.

BUILD I - The first build of the rig utilized a ballast ring packing shown in Figure 4-5. The height of the packed bed was 10 inches. The spray cooler was tested initially with the water nozzle spraying in the direction of the hot gas flow, then reversed to spray counter to the gas stream. Spray cooler performance was acceptable in both configurations, at gas flows corresponding to about $100 \mathrm{~kW}$. The gas exit temperature was reduced to $260^{\circ} \mathrm{F}$, which meets requirements for complete acid removal. A system heat balance was obtained, indicating all the water was vaporized. At higher gas flows (representing that of a 150- to 200-kW operation) neither of the two configurations performed satisfactorily. The water was not fully vaporized in the distance between the spray nozzle and bottom of the packed bed, resulting in water collecting in the sump and a high gas exit temperature.

To improve water vaporization at full power flow rates, the height of the packed bed was increased from 10 inches to 16 inches. The increased bed height did not produce acceptable performance at the $200-\mathrm{kW}$ operating point; water still collected in the sump, indicating incomplete vaporization. There was no significant reduction in water carryover into the sump for the increased bed height, indicating the packing material was not providing an effective surface for vaporization. 


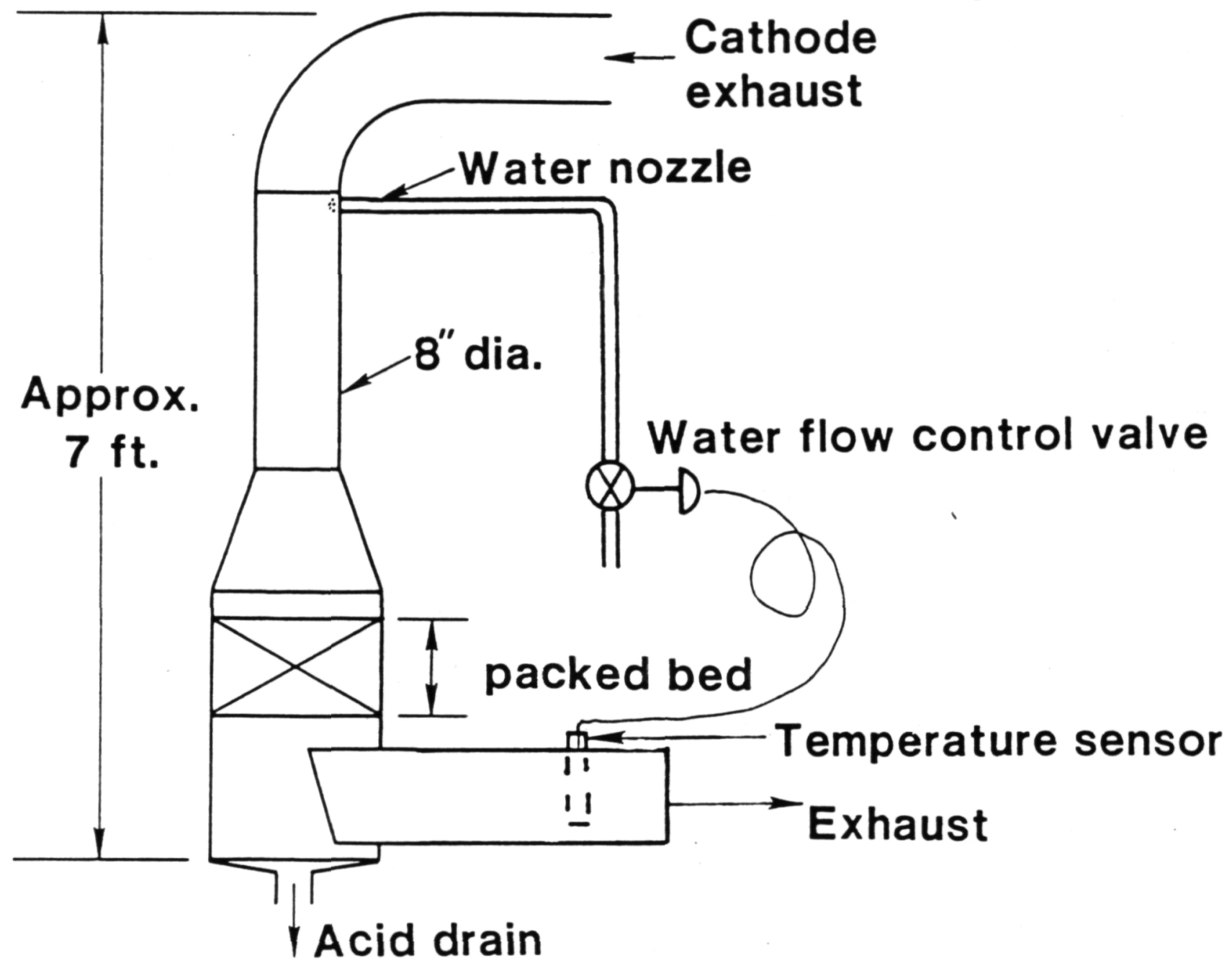

Figure 4-3. Evaporative Spray Cooler Rig for 200-kW System - Schematic 
Power Systems Division

ORIGINAL PAGE IS

FCR-5715

OF POOR QUALTTY

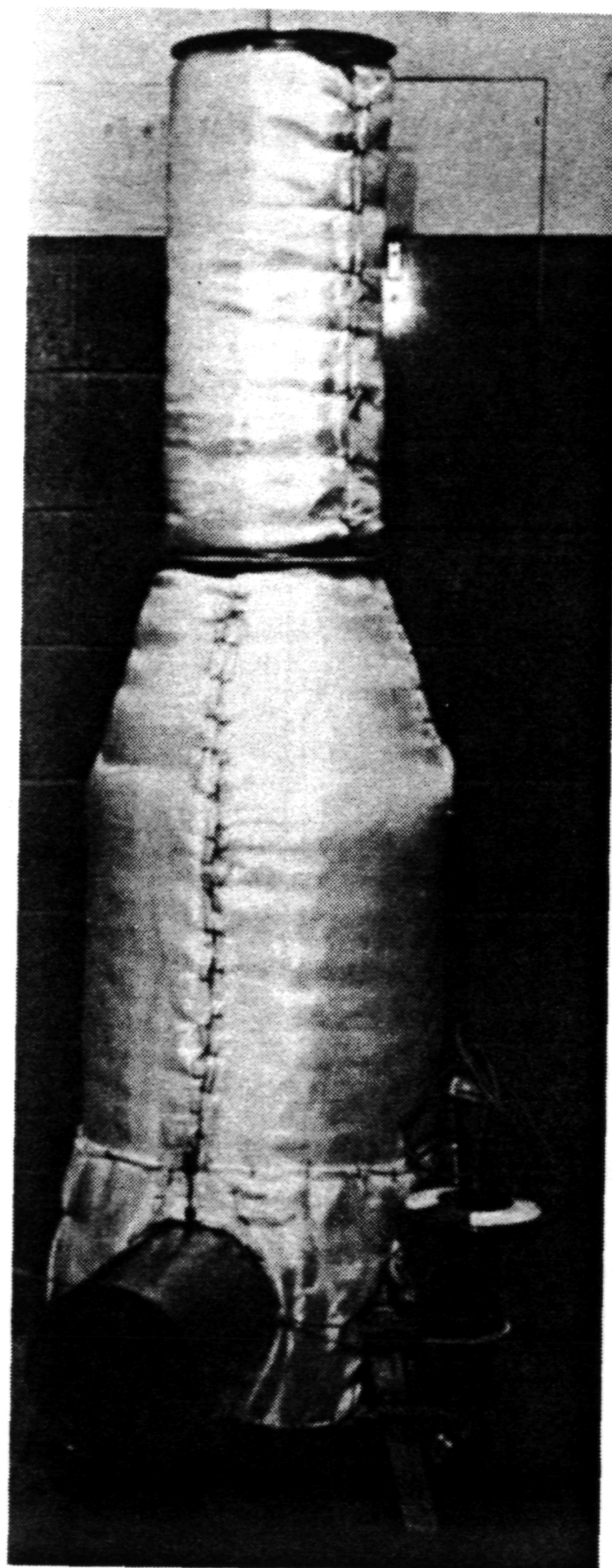

WCN-10011

Figure 4-4. Evaporative Spray Cooler Rig 


\section{ORIGINAL PAGE IS
OF POOR QUALITY}

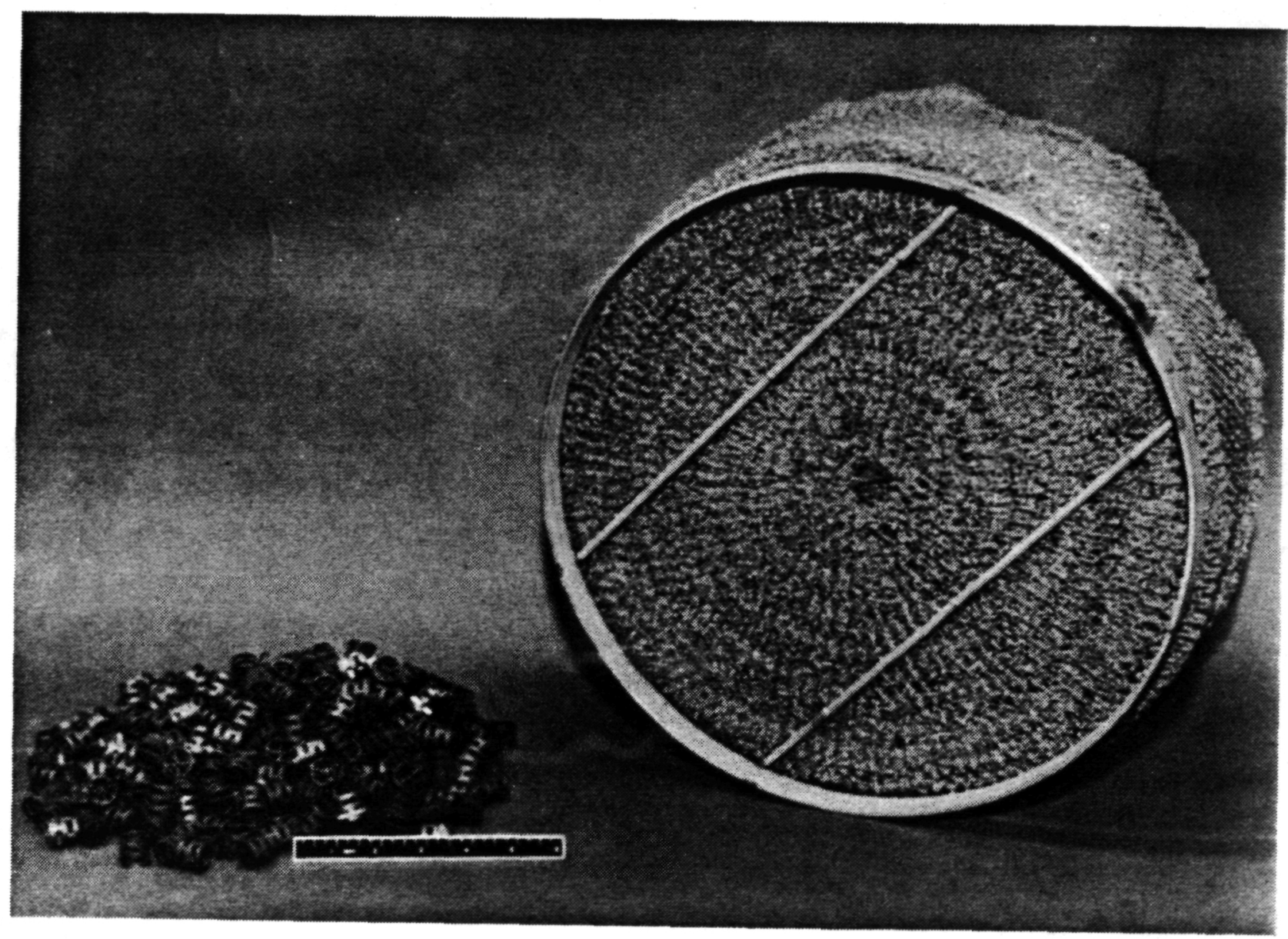

WCN-10704

Figure 4-5. Ballast Ring Packing (Left) and Wire Mesh Packing Evaluated in Evaporative Spray Cooler Rig 
BUILD II - In the second build of the rig, a stainless steel wire mesh packing was tested. A significant performance improvement was obtained with this packing. At the $200-\mathrm{kW}$ operating point, the amount of water carryover into the sump due to incomplete vaporization was about 50\% less than with the ballast ring packing. The total pressure drop of the spray cooler rig was well within the allocation. The wire mesh packing is shown in Figure 4-5.

BUILD III - Build III of the rig used a higher density stainless steel wire mesh packing to improve water vaporization at high power points. Testing with the higher density packing produced acceptable results at the $200-\mathrm{kW}$ operating point. There was no water carryover into the sump, and the gas stream exit temperature measured $20^{\circ} \mathrm{F}$ below the requirement for complete acid removal. The pressure drop was acceptable.

Testing of the evaporative water spray cooler up to this point had been conducted with a dry gas inlet stream. A test was then conducted with a humidified gas inlet stream, to determine whether there would be a significant performance difference. The gas inlet stream was humidified to $67 \%$ of the cathode exhaust moisture level, the maximum amount of humidification that could be obtained without significant changes to the test stand steam supply system. Performance at this level was acceptable. There was no water carryover into the sump, therefore the exit temperature was the same as obtained in the test with a dry gas inlet stream. Water breakthrough did not occur until the water spray flow was increased by $25 \%$ and the stream was cooled an additional $20^{\circ} \mathrm{F}$.

On the basis of these results, it was analytically determined that the 6-inch bed height should be increased by about $30 \%$ to insure that no water breakthrough would occur at the $100 \%$ cathode exhaust stream moisture level. To provide an operating margin, a $50 \%$ increase in bed height will be specified. This does not present a problem, since the cost of increasing the bed height from 6 inches to 9 inches is minimal and pressure drop will still be within allocation. 
An acceptable water flow control system has not been identified for the evaporative spray cooler. Testing with the standard commercial temperature sensing water flow control valve did not provide acceptable control. Definition of an alternative water flow control device was not pursued in this program.

TABLE 4-2. WATER SPRAY ACID CONDENSER TEST RESULTS

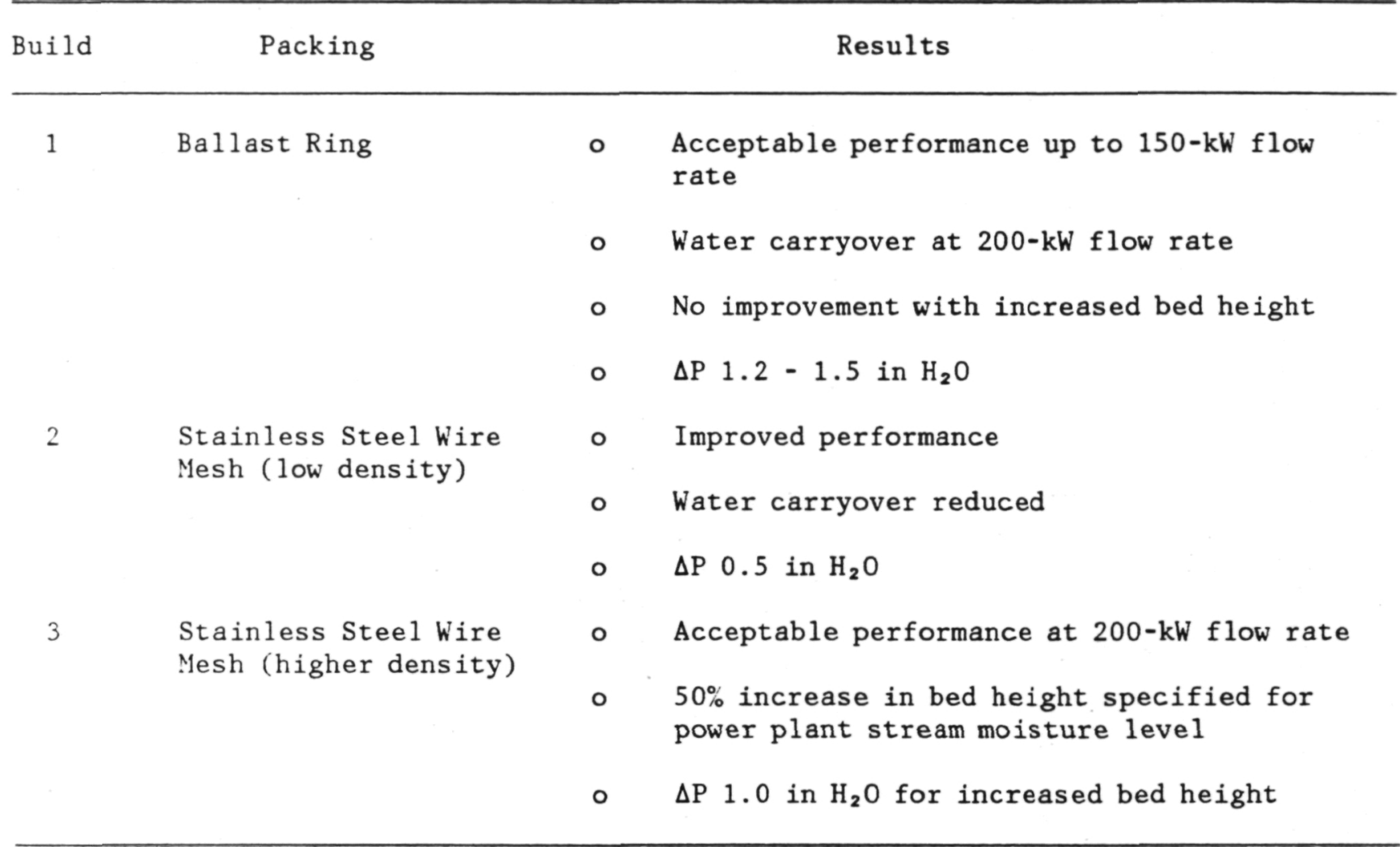

Contact Saturator - A contact saturator was evaluated to determine its ability to reduce the cathode exhaust stream temperature to the level required for acid condensation. Details of the contact saturator configuration cannot be disclosed at this time due to patent considerations. A contact saturator rig was assembled for a $200-\mathrm{kW}$ system. Testing of the initial build of the contact saturator rig resulted in the gas stream being cooled to approximately the saturation temperature of the gas stream used in the test. This is significantly lower than the temperature required for complete acid condensation. The system performance impact of cooling 
the cathode exhaust stream below the optimum $250-270^{\circ} \mathrm{F}$ temperature range is being assessed.

The water flow rate was decreased to demonstrate that the degree of cooling could be reduced if required. At this condition a higher gas stream exit temperature was obtained. This result indicates it is possible to define a configuration that cools to any desired temperature.

The contact saturator approach to acid removal is considered a viable method. This method utilizes basic components that do not require complex controls.

\section{Conclusion}

Table 4-3 summarizes characteristics of the three candidate acid condenser devices evaluated in this program. The preferred acid condenser device for the present on-site baseline system is the heat exchanger with Teflon covered metal tubes and Teflon lined enclosure. The higher cost of this heat exchanger, relative to the water cooling approaches, is offset by its advantages: system simplification, system performance, reliability, life, and maintenance. The alternative selection is the contact saturator, which has less control complexity and higher reliability than the evaporative water spray cooler.

Additional activity to investigate a potentially lower cost approach to the acid condenser heat exchanger is planned in the 1984 GRI and NASA On-Site Programs. This effort will address an uncoated metal heat exchanger, designed to operate with all surfaces (including the shell or enclosure) acting as heat exchanger surfaces. This maintains moderately low metal temperatures throughout, which reduces corrosion rates. Corrosion rates will be determined through laboratory tests and 40-kW field experience with uncoated stainless steel heat exchanger plates. If life and cost projections of this approach appear favorable, a prototype heat exchanger will be procured for experimental evaluation. 

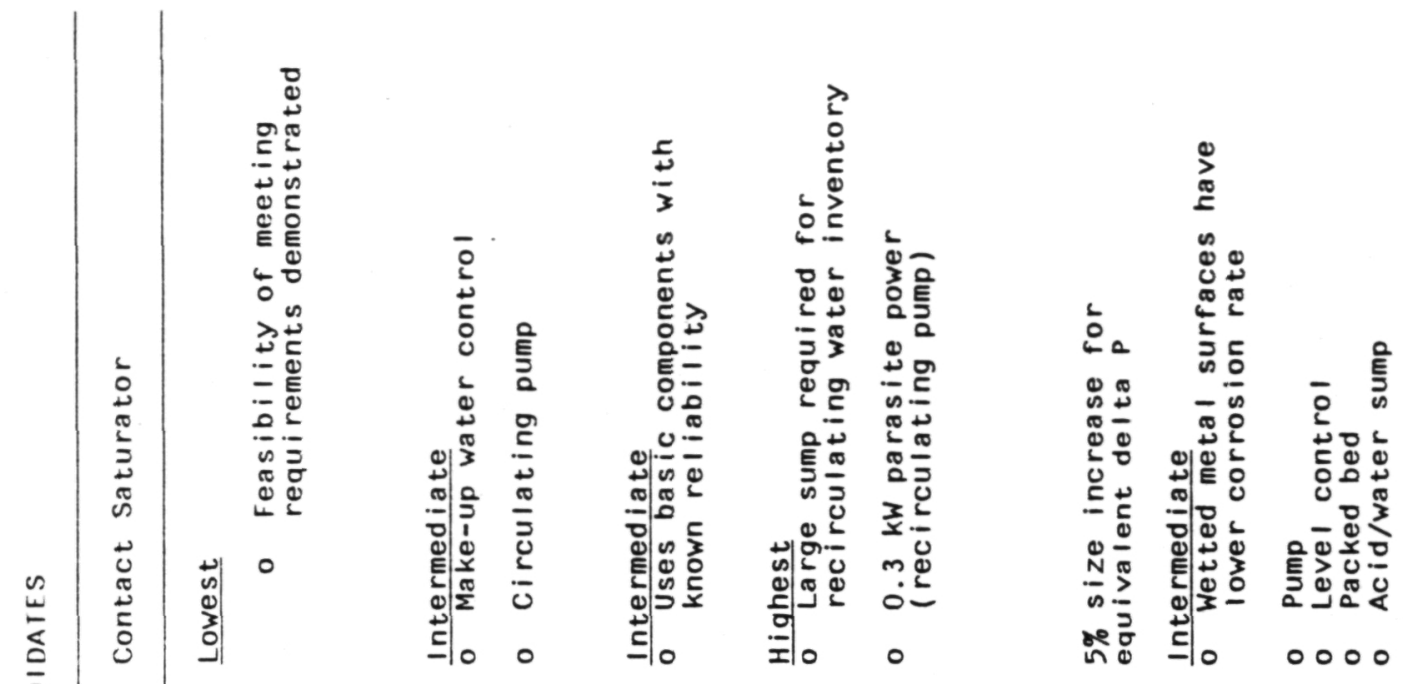

s

(1)

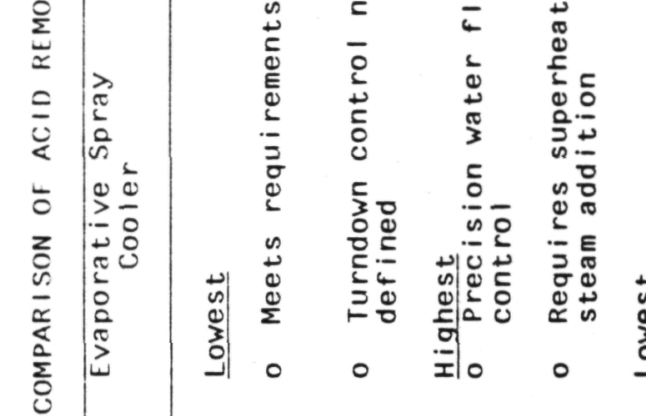

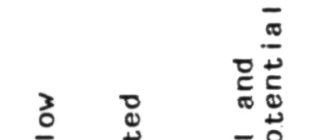

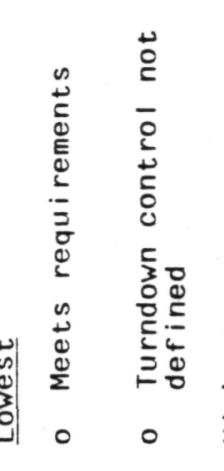

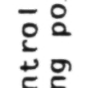

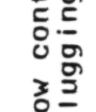

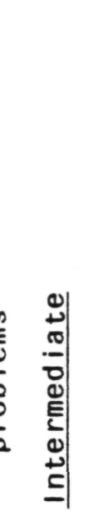

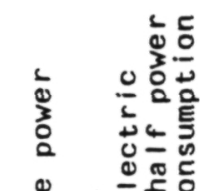

ن

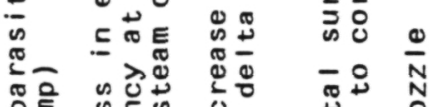

文言 का

次 包

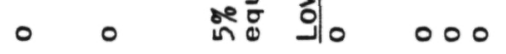

$\dot{m}$
$\dot{5}$
$\dot{\vec{x}}$
$\leq$
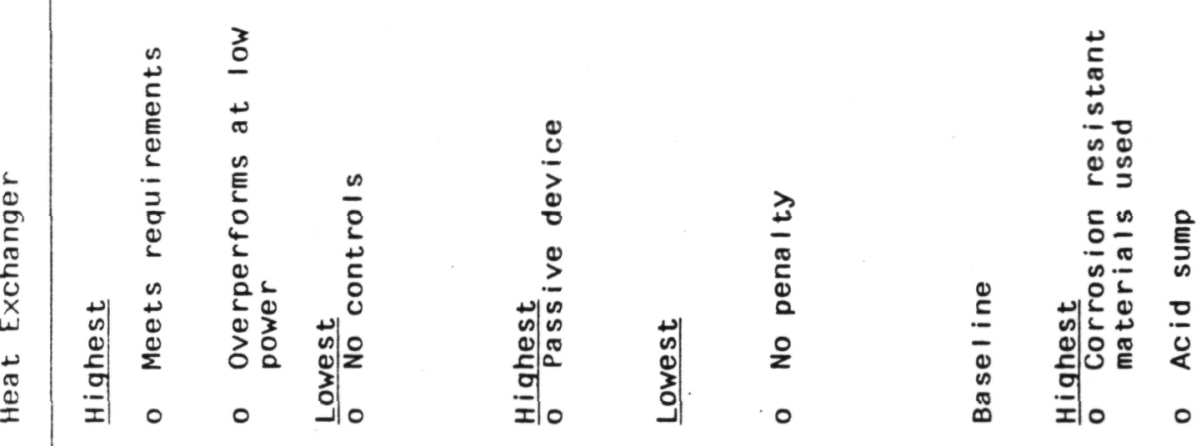

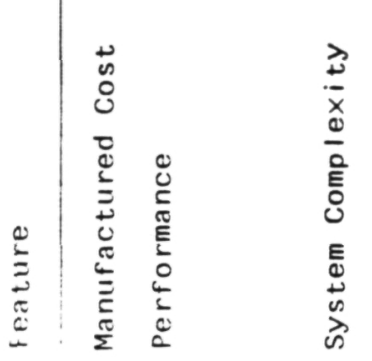

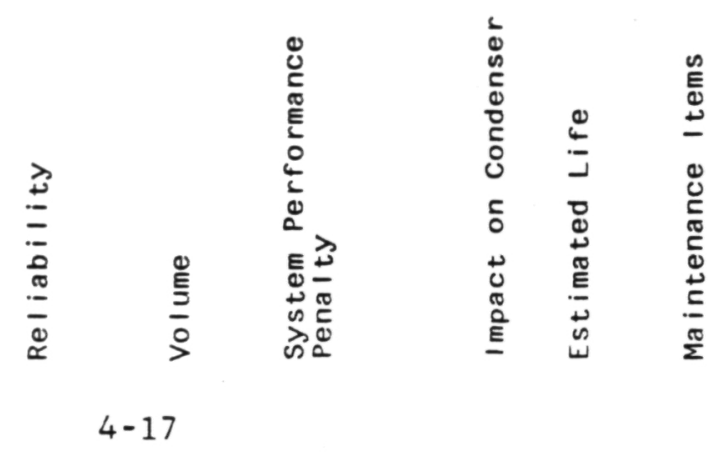


TASK 5 FUEL PROCESSOR DEVELOPMENT 
TASK 5 - FUEL PROCESSOR DEVELOPMENT

\section{Subtask 5.1 Develop Fuel Processor Catalyst Technology}

\section{Objective}

The objective of this subtask is to define hydrodesulfurization and low temperature shift catalyst characteristics in order to minimize the bed sizes, and to define reforming catalyst performance and pressure drop in order to optimize the packaging configuration (length/diameter ratio) of the reformer.

\section{Summary}

Several reforming catalysts were identified which have significantly lower pressure drop than the $40 \mathrm{~kW}$ catalyst. Low pressure drop reforming catalyst is important to the design of the $200 \mathrm{~kW}$ development reformer, as it allows the required catalyst volume to be packaged into fewer longer tubes, for reduced cost. The catalysts were identified via visits and telephone contacts with catalyst vendors. Of eight candidate catalysts tested, four were found to have performance equivalent to that of the $40-\mathrm{kW}^{\prime}$ catalyst. One of these has been selected for evaluation in the endurance test, since its small size permits design of a reformer with a thinner bed than would be possible with the other catalysts.

An alternative shift converter catalyst has been identified to have higher performance than the $40-\mathrm{kW}$ catalyst. Since the long-term life characteristics of the $40-\mathrm{kh}$ catalyst are known, this new catalyst has been selected for endurance test evaluation. This test could then be used as a basis for qualifying this catalyst for use in on-site power plants. 
A hydrodesulfurizer catalyst has been prepared by PSD. This catalyst does not require the costly, time-consuming presulfiding operation required for the $40-\mathrm{kW}$ catalyst. Problems were encountered during performance testing of this alternate catalyst, however, which called for analysis of the extremely low sulfur concentrations in the gas streams. This resulted in a delay in test completion and selection of catalyst for the endurance test.

\section{Highlights}

- Selected a reforming catalyst for the endurance test having significantly lower pressure drop and equivalent performance to the $40-\mathrm{kW}$ catalyst.

o Selected an alternate shift converter catalyst for stability testing in the endurance test.

\section{Discussion}

Reformer catalyst testing was conducted in an electrically heated subscale reactor capable of testing catalysts under controlled temperature conditions. The pressure drop and heat transfer effects in this reactor are analogous to those found in full-scale reformers. A schematic diagram of the reactor is shown in Figure 5.1-1. The reactor is 46.5 inches in length and has an I.D. of 1.38 inches. Sample taps are located at intermediate positions along the length of the reactor so that the degree of fuel conversion can be determined along the length of the reactor as well as at the reactor exit. The temperature in each of the reactor sections is controlled by separate heaters that can be adjusted to maintain constant wall temperatures for a variety of conditions. A photograph of the reactor installed in the furnace is shown in Figure 5.1-2. 
ORIGINAL PAGE IS

OF. POOR QUALITY

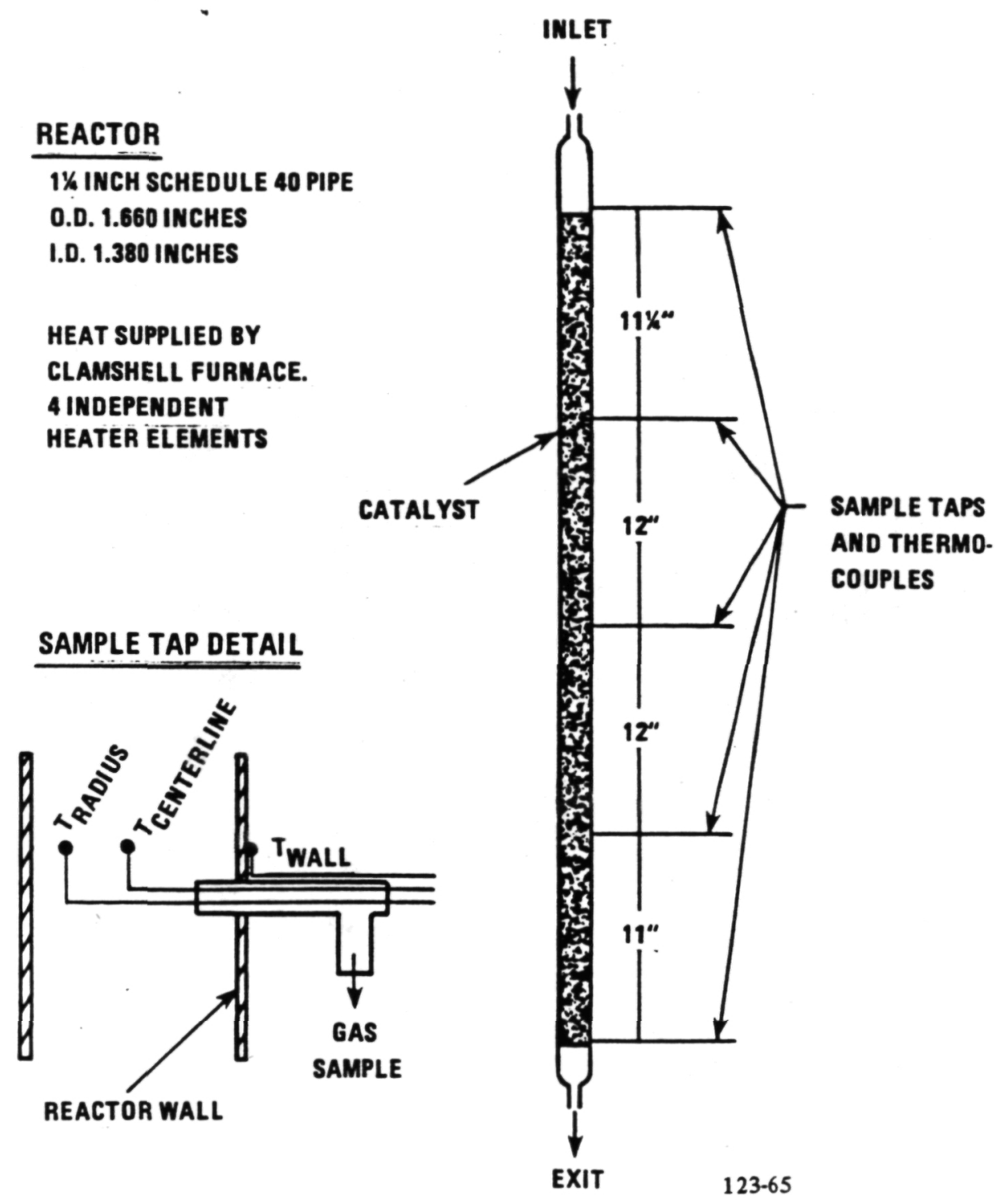

Figure 5.1-1. Subscale Reactor Schematic 


\section{ORIGINAL' PAGE IS \\ OF POOR QUALTTY}

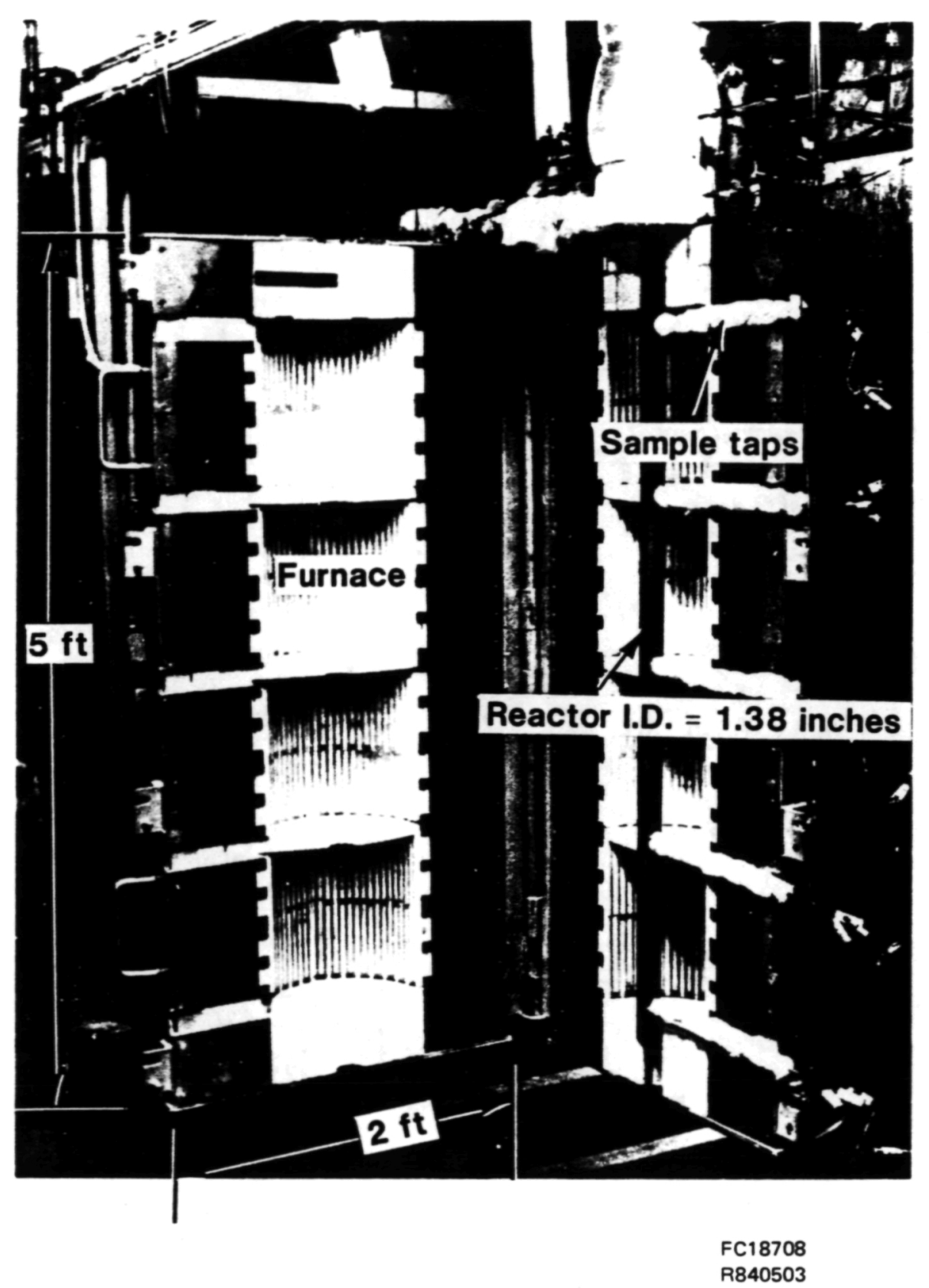

Figure 5.1-2. Subscale Reactor and Furnace 
A total of eight candidate catalysts plus the $40-\mathrm{kW}$ reformer catalyst were tested. Figure 5.1-3 shows a comparison of the data for the 40-kW catalyst and three of the candidate catalysts. As shown by the data in the figure, varying degrees of pressure drop reduction can be attained while maintaining good reform conversion at the reactor exit. Reforming conversion for these catalysts was also measured at the intermediate taps along the length of the reactor. The results indicate that there is very little difference in reform conversion between the $40-\mathrm{kW}$ catalysts and the low pressure catalysts (Figure 5.1-4). The data presented in the two figures above were taken at a mass flux (lbs. of fuel/hr. per unit reactor cross section) equal to the mass flux used in the $200-\mathrm{kW}$ reformer design. Reactants were fed to the reformer at $650^{\circ} \mathrm{F}$ and the same reactor wall temperature profile was maintained for all the catalysts with a $1400^{\circ} \mathrm{F}$ wall temperature at exit (see Table 5.1-1). The $1 x$ tests were run at a space velocity of $17.1 \mathrm{lbs}$. fuel/ft $\mathrm{ft}^{2} \mathrm{hr}$. Tests were also run at more severe conditions where the mass flux was twice that of the present $200-\mathrm{kW}$ design mass $f l u x$, and a $1500^{\circ} \mathrm{F}$ wall temperature was maintained at the reactor exit. The $2 \mathrm{x}$ tests were run at space velocity of $34.2 \mathrm{lbs}$. fuel/ $\mathrm{ft}^{2}-\mathrm{hr}$. Results of these more severe conditions are shown in Figure 5.1-5. The reform conversions in this figure show only a small difference between the lowest pressure drop catalyst and the $40-\mathrm{kW}$ catalyst. Data for all the catalysts tested are listed in Tables 5.1-2 and 5.1-3. The data for catalysts not shown in the foregoing figures but listed in the table are slightly lower than for the three catalysts used in the illustration. 


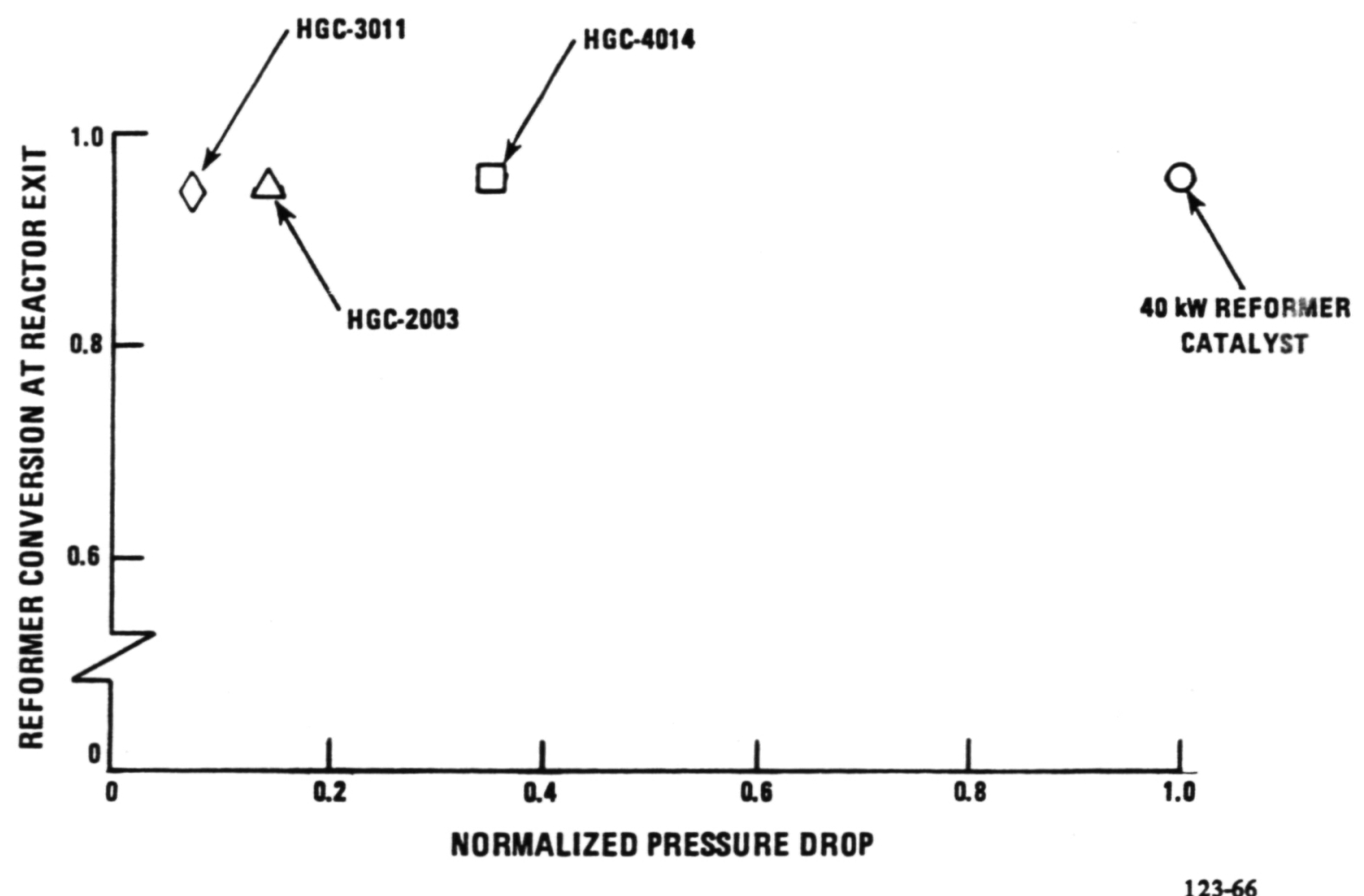

Figure 5.1-3. Low $\Delta \mathrm{P}$ Catalysts Reform Conversion 


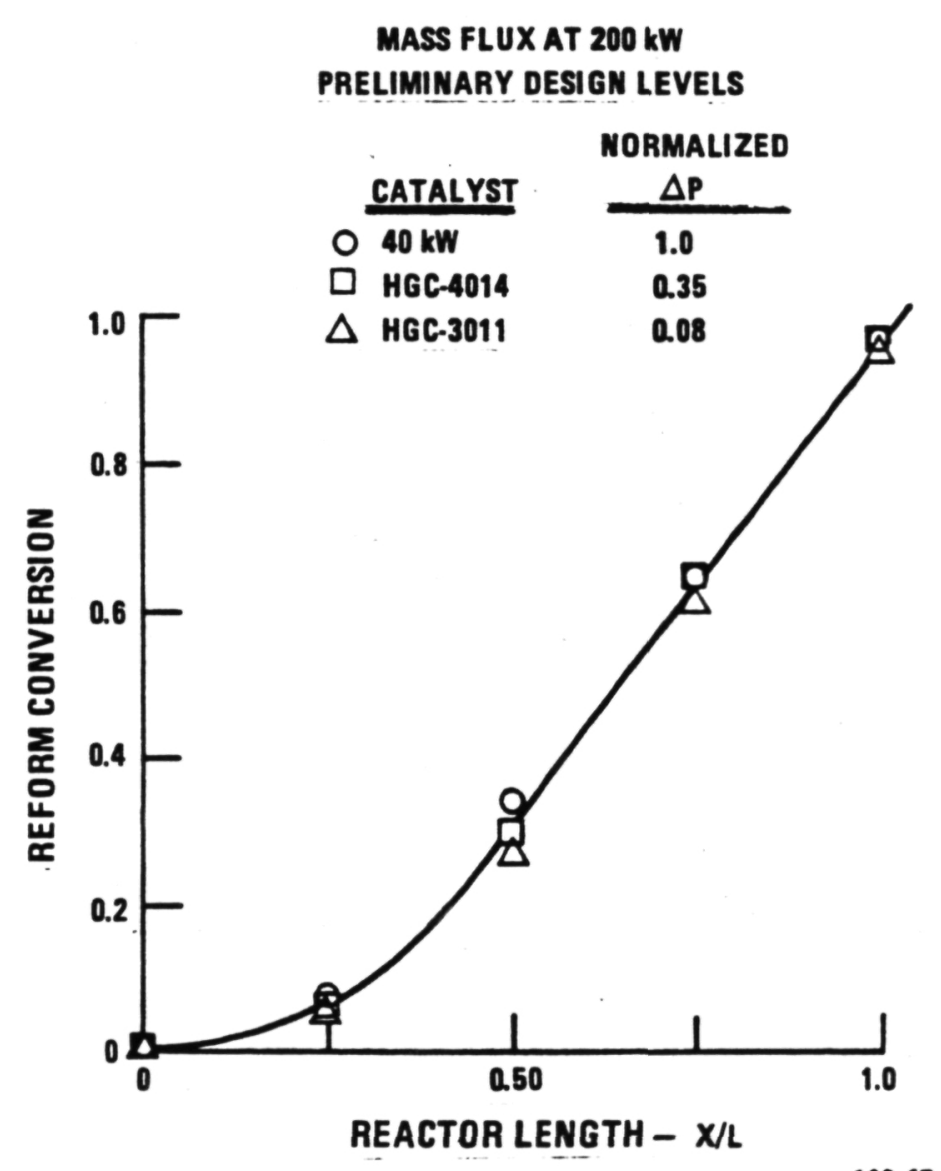

Figure 5.1-4. Reform Conversion with Reduced $\Delta$ P Catalysts 
TABLE 5.1-1. WALL TEMPERATURE PROFILES

(Temperatures in ${ }^{\circ} \mathrm{F}$ )

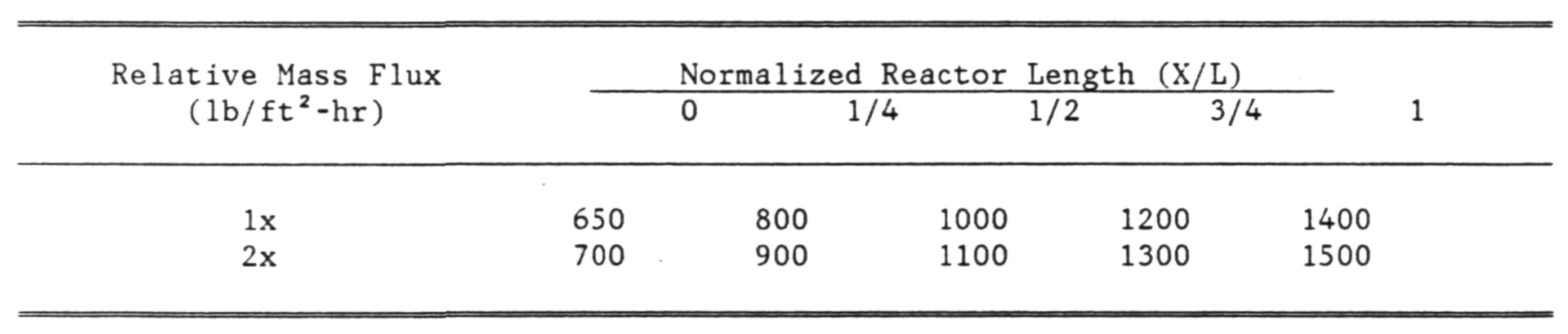

HCG-4014 has been selected as the reforming catalyst for the endurance test, since its small size permits design of a reformer with a thinner bed than would be possible with some of the other catalysts. The thinner bed minimizes the catalyst volume required. 


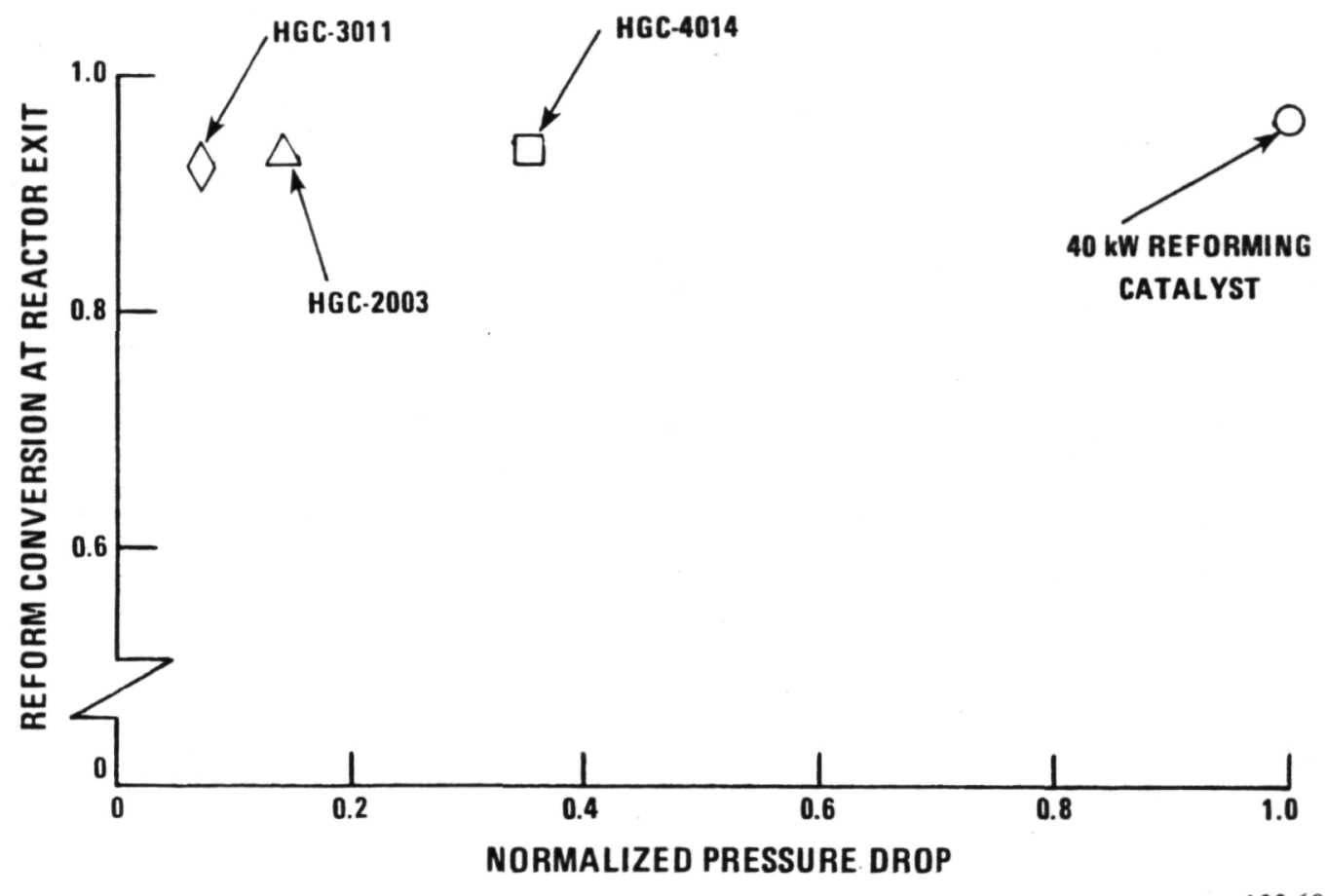

Figure 5.1-5. Performance of Catalysts at 2x Design Mass Flux 


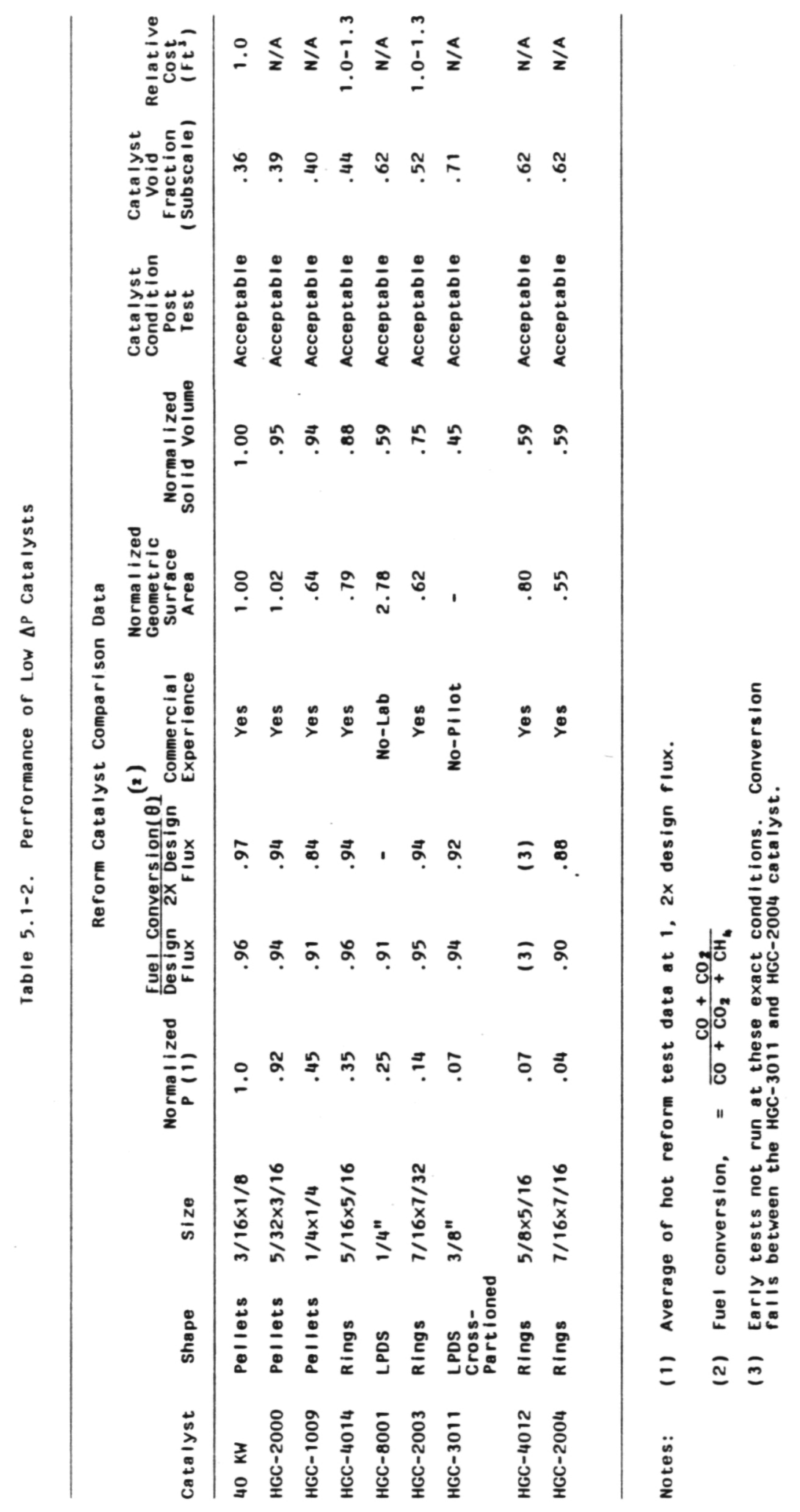




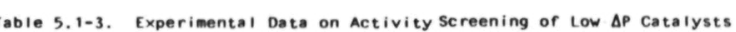

\begin{tabular}{|c|c|c|c|c|c|c|c|c|c|c|c|c|c|c|c|c|c|c|c|c|c|c|c|c|c|c|c|c|c|c|}
\hline \multirow{2}{*}{ 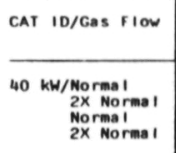 } & \multicolumn{3}{|c|}{$\begin{array}{l}\text { Axial Temp, Location } \\
\text { Hail } \\
\Delta\end{array}$} & \multicolumn{2}{|c|}{$\frac{x / L=0}{\Delta \quad \text { center }}$} & \multicolumn{3}{|c|}{$\begin{array}{l}\text { Axial Temp. Location } \\
\text { Wail } \\
\Delta\end{array}$} & \multicolumn{2}{|c|}{$\frac{x / L=.25}{\Delta \text { Center }}$} & \multicolumn{5}{|c|}{$\begin{array}{l}\text { Axial Temp. Location } \\
\text { Wail }\end{array}$} & \multicolumn{3}{|c|}{$\frac{\text { Axial Temp. Location }}{\text { Wall }} \Delta \frac{\text { Radius }}{\text { Rat }}$} & \multicolumn{2}{|c|}{$x / L=\frac{.75}{\text { center }}$} & \multicolumn{3}{|c|}{$\begin{array}{l}\text { Axial Iemp. Location } \\
\text { Wail } \\
\Delta\end{array}$} & \multicolumn{2}{|c|}{$\frac{x / L}{\Delta}=\frac{1,0}{\text { Center }}$} & \multicolumn{5}{|c|}{$\begin{array}{l}\text { Methann Conversion at various } \times / 1 \\
0.0 \\
0.0 \%\end{array}$} \\
\hline & $\begin{array}{l}747 \\
832 \\
751 \\
882\end{array}$ & $\begin{array}{r}98 \\
120 \\
955 \\
171\end{array}$ & $\begin{array}{l}649 \\
712 \\
656 \\
711\end{array}$ & $\begin{array}{c}12 \\
16 \\
0 \\
8\end{array}$ & $\begin{array}{l}637 \\
696 \\
656 \\
703\end{array}$ & $\begin{array}{l}797 \\
8994 \\
800 \\
892\end{array}$ & $\begin{array}{r}60 \\
110\end{array}$ & $\begin{array}{l}737 \\
784 \\
=:\end{array}$ & $\begin{array}{l}4 \\
5\end{array}$ & $\begin{array}{l}733 \\
779 \\
7722 \\
764\end{array}$ & $\begin{array}{r}996 \\
1093 \\
999 \\
1098\end{array}$ & $\begin{array}{r}51 \\
89 \\
69 \\
117\end{array}$ & $\begin{array}{r}945 \\
1004 \\
930 \\
981\end{array}$ & $\begin{array}{l}44 \\
63 \\
15 \\
16\end{array}$ & $\begin{array}{l}901 \\
941 \\
915 \\
965\end{array}$ & $\begin{array}{l}1196 \\
1998 \\
1200 \\
1301\end{array}$ & $\begin{array}{r}46 \\
91 \\
105 \\
170\end{array}$ & $\begin{array}{l}1150 \\
1207 \\
1095 \\
1131\end{array}$ & $\begin{array}{r}83 \\
117 \\
5 \\
6\end{array}$ & $\begin{array}{l}1067 \\
1090 \\
1090 \\
1125\end{array}$ & $\begin{array}{l}1404 \\
1500 \\
1400 \\
1499 \\
4999\end{array}$ & $\begin{array}{r}73 \\
199 \\
992 \\
960\end{array}$ & $\begin{array}{l}1331 \\
1331 \\
1331 \\
1330 \\
1339\end{array}$ & $\begin{array}{l}71 \\
49 \\
40 \\
24\end{array}$ & $\begin{array}{l}1310 \\
1322 \\
13268 \\
1315\end{array}$ & 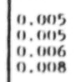 & $\begin{array}{l}0.085 \\
0.1114 \\
0.013 \\
0.098\end{array}$ & $\begin{array}{l}10.3727 \\
0.395 \\
6.340 \\
0.440\end{array}$ & 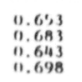 & $\begin{array}{l}10.965 \\
0.968 \\
0.9964 \\
0.9713\end{array}$ \\
\hline $\begin{array}{l}\text { HGC-4014/Morma! } \\
2 \times \text { Norma }\end{array}$ & $\begin{array}{l}703 \\
834\end{array}$ & ${ }_{144}^{127}$ & $\begin{array}{l}576 \\
690\end{array}$ & 8 & $\begin{array}{l}567 \\
682\end{array}$ & $\begin{array}{l}803 \\
900\end{array}$ & $\begin{array}{l}53 \\
944\end{array}$ & $\begin{array}{l}750 \\
806\end{array}$ & ${ }_{2}^{2}$ & $\begin{array}{l}7488 \\
804\end{array}$ & $\begin{array}{l}1001 \\
1099\end{array}$ & $\begin{array}{r}68 \\
120\end{array}$ & 933 & $\begin{array}{l}33 \\
40\end{array}$ & $\begin{array}{l}900 \\
939\end{array}$ & $\begin{array}{l}1200 \\
1299\end{array}$ & $\begin{array}{l}48 \\
99\end{array}$ & $\begin{array}{l}1152 \\
1200\end{array}$ & $\begin{array}{r}81 \\
109\end{array}$ & $\begin{array}{l}1071 \\
1091\end{array}$ & $\begin{array}{l}1401 \\
1500\end{array}$ & $\begin{array}{l}72 \\
135\end{array}$ & $\begin{array}{l}1329 \\
1365\end{array}$ & 413 & $\begin{array}{l}1316 \\
1324\end{array}$ & $\begin{array}{l}0.006 \\
0.0166\end{array}$ & $\begin{array}{l}0.061 \\
\text { 0.0855 }\end{array}$ & $\begin{array}{l}0.296 \\
0.342\end{array}$ & $\begin{array}{l}0.641 \\
0.651\end{array}$ & $\begin{array}{l}\text { 8.961 } \\
0.9441\end{array}$ \\
\hline $\begin{array}{l}\text { MGC-2003/Normas } \\
2 \times \text { Norma I }\end{array}$ & $\begin{array}{l}8144 \\
1028\end{array}$ & $\begin{array}{l}162 \\
310\end{array}$ & $\begin{array}{l}652 \\
118\end{array}$ & $\frac{14}{14}$ & $\begin{array}{l}638 \\
704\end{array}$ & $\begin{array}{l}804 \\
899\end{array}$ & $\begin{array}{l}-69 \\
-150\end{array}$ & $\begin{array}{l}873 \\
1049\end{array}$ & $\begin{array}{l}92 \\
88\end{array}$ & $\begin{array}{l}781 \\
861\end{array}$ & $\begin{array}{l}1003 \\
1099\end{array}$ & & $=$ & & $\begin{array}{l}918 \\
983\end{array}$ & 11989 & $\begin{array}{l}89 \\
128\end{array}$ & 11109 & $\begin{array}{l}28 \\
46\end{array}$ & $\begin{array}{l}1081 \\
1125\end{array}$ & $\begin{array}{l}1400 \\
1500\end{array}$ & $\begin{array}{l}131 \\
181\end{array}$ & $\begin{array}{l}1269 \\
1319\end{array}$ & $\begin{array}{l}-65 \\
-64\end{array}$ & $\begin{array}{l}1334 \\
1383\end{array}$ & $\mid \begin{array}{l}0.006 \\
0.006\end{array}$ & $\begin{array}{l}0.121 \\
0.188\end{array}$ & $\begin{array}{l}0.324 \\
0.420\end{array}$ & $\begin{array}{l}0.635 \\
0.694\end{array}$ & $\begin{array}{l}0.952 \\
0.956\end{array}$ \\
\hline $\begin{array}{l}\text { HGC-3011/Normas } \\
2 \times \text { Norma }\end{array}$ & $\begin{array}{l}745 \\
844\end{array}$ & 99 & $\begin{array}{l}651 \\
697\end{array}$ & $\begin{array}{c}-5 \\
1\end{array}$ & $\begin{array}{l}656 \\
696\end{array}$ & $\begin{array}{l}788 \\
901\end{array}$ & $\begin{array}{l}45 \\
80\end{array}$ & $\begin{array}{l}743 \\
821\end{array}$ & $\begin{array}{l}15 \\
27\end{array}$ & $\begin{array}{l}728 \\
794\end{array}$ & $\begin{array}{l}985 \\
1099\end{array}$ & & $=$ & & $\begin{array}{l}8888 \\
945\end{array}$ & 1301 & י1199 & 11138 & $\begin{array}{r}77 \\
108\end{array}$ & $\begin{array}{l}1061 \\
1082\end{array}$ & $\begin{array}{l}1409 \\
1502\end{array}$ & $\begin{array}{l}104 \\
200\end{array}$ & $\begin{array}{l}1305 \\
1302\end{array}$ & $\stackrel{-6}{9}$ & 1311 & $\begin{array}{l}0.005 \\
0.005\end{array}$ & $\begin{array}{l}0.049 \\
0.091\end{array}$ & $\begin{array}{l}0.263 \\
0.300\end{array}$ & $\begin{array}{l}0.6018 \\
0.596\end{array}$ & $\begin{array}{l}0.945 \\
0.924\end{array}$ \\
\hline $\begin{array}{l}\text { HGC-2000/Norma: } \\
2 x \text { Norras I }\end{array}$ & $\begin{array}{l}739 \\
848\end{array}$ & 134 & $\begin{array}{l}668 \\
714\end{array}$ & 18 & $\begin{array}{l}650 \\
698\end{array}$ & $\begin{array}{l}796 \\
892\end{array}$ & $\begin{array}{l}52 \\
89\end{array}$ & $\begin{array}{l}744 \\
803\end{array}$ & ${ }_{29}^{20}$ & $\begin{array}{l}724 \\
774\end{array}$ & $\begin{array}{l}997 \\
1092\end{array}$ & $\begin{array}{l}52 \\
93\end{array}$ & $\begin{array}{l}945 \\
999\end{array}$ & $\begin{array}{l}53 \\
66\end{array}$ & $\begin{array}{l}8922 \\
933\end{array}$ & $\begin{array}{l}1199 \\
1296\end{array}$ & $\begin{array}{l}67 \\
131\end{array}$ & 11132 & ${ }_{68}^{58}$ & $\begin{array}{l}1074 \\
1097\end{array}$ & $\begin{array}{l}1400 \\
1497\end{array}$ & $\begin{array}{r}91 \\
152\end{array}$ & $\begin{array}{l}1309 \\
1345\end{array}$ & $\begin{array}{l}22 \\
45\end{array}$ & $\begin{array}{l}1287 \\
1330\end{array}$ & $\begin{array}{l}0.006 \\
0.0166\end{array}$ & $\begin{array}{l}0.068 \\
0.096\end{array}$ & $\begin{array}{l}\begin{array}{l}0.309 \\
0.359\end{array} \\
0.35\end{array}$ & $\begin{array}{l}0.600 \\
0.632\end{array}$ & $\begin{array}{l}0.935 \\
0.942\end{array}$ \\
\hline $\begin{array}{l}\text { HGC-1009/Normas } \\
2 \times \text { Normo }\end{array}$ & $\begin{array}{l}709 \\
783\end{array}$ & & $\because$ & & $\begin{array}{l}643 \\
698\end{array}$ & $\begin{array}{l}802 \\
898\end{array}$ & $\begin{array}{l}57 \\
97\end{array}$ & $\begin{array}{l}745 \\
801\end{array}$ & 6 & $\begin{array}{l}739 \\
794\end{array}$ & $\begin{array}{l}1005 \\
1097\end{array}$ & $\begin{array}{r}79 \\
103\end{array}$ & $\begin{array}{l}926 \\
994\end{array}$ & $\begin{array}{l}47 \\
64\end{array}$ & $\begin{array}{l}879 \\
930\end{array}$ & $\begin{array}{l}1203 \\
1302\end{array}$ & $\begin{array}{l}44 \\
80\end{array}$ & $\begin{array}{l}1159 \\
1222\end{array}$ & $\begin{array}{l}130 \\
143\end{array}$ & $\begin{array}{l}1029 \\
1079\end{array}$ & $\begin{array}{l}1403 \\
1497\end{array}$ & 112 & $\begin{array}{l}1291 \\
1363\end{array}$ & $\begin{array}{l}14 \\
70\end{array}$ & $\begin{array}{l}2177 \\
1293\end{array}$ & $\begin{array}{l}0.005 \\
0.005\end{array}$ & $\begin{array}{l}0.065 \\
0.007\end{array}$ & $\begin{array}{l}0.253 \\
0.254\end{array}$ & $\begin{array}{l}0.547 \\
0.513\end{array}$ & $\begin{array}{l}0.912 \\
0.840\end{array}$ \\
\hline $\begin{array}{l}\text { HCG-8001/Norma: } \\
2 x^{2} \text { Norras I }\end{array}$ & 721 & 66 & 655 & 3 & 652 & 800 & $\begin{array}{r}29 \\
0\end{array}$ & 771 & 9 & 762 & 999 & 75 & 924 & 3 & 921 & 1201 & 72 & 1129 & 93 & 1036 & 1400 & 143 & 1257 & 3 & 1254 & 0.009 & 0.016 & 0.147 & 0.505 & 0.906 \\
\hline $\begin{array}{l}\text { HCC-2004/Norms: } \\
2 \times \text { Norma i }\end{array}$ & $\begin{array}{l}{ }_{837}^{737} \\
839\end{array}$ & $\begin{array}{l}86 \\
175\end{array}$ & $\begin{array}{l}651 \\
664\end{array}$ & $\stackrel{8}{13}$ & $\begin{array}{l}643 \\
651\end{array}$ & $\begin{array}{l}791 \\
895\end{array}$ & $\begin{array}{r}54 \\
106\end{array}$ & $\begin{array}{l}737 \\
789\end{array}$ & 2 & $\begin{array}{l}735 \\
788\end{array}$ & $\begin{array}{l}990 \\
1086\end{array}$ & $\begin{array}{l}50 \\
99\end{array}$ & $\begin{array}{l}940 \\
987\end{array}$ & $\begin{array}{l}38 \\
36\end{array}$ & $\begin{array}{l}902 \\
951\end{array}$ & 1193 & $\begin{array}{l}21 \\
55\end{array}$ & 1172 & $\begin{array}{l}141 \\
188\end{array}$ & $\begin{array}{l}1031 \\
1045\end{array}$ & $\begin{array}{l}1400 \\
1492\end{array}$ & $\begin{array}{r}69 \\
146\end{array}$ & $\begin{array}{l}1331 \\
1346\end{array}$ & $\begin{array}{l}27 \\
21\end{array}$ & $\begin{array}{l}1304 \\
1325\end{array}$ & $\begin{array}{l}0.005 \\
0.005\end{array}$ & $\begin{array}{l}0.051 \\
0.061\end{array}$ & $\begin{array}{l}0.211 \\
0.266\end{array}$ & $\begin{array}{l}0.537 \\
0.545\end{array}$ & $\begin{array}{l}\mathbf{0 . 8 9 8} \\
0.885\end{array}$ \\
\hline
\end{tabular}

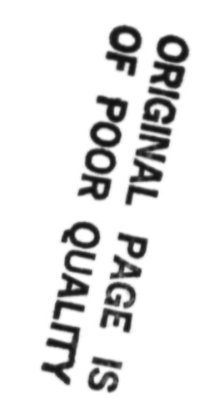


A shift converter catalyst having activity comparable to that of the $40-\mathrm{kW}$ catalyst has only been available from one source. An effort was made, therefore, to identify an alternative source for such a catalyst. This has been done and vendor performance data from this alternate catalyst shows that its activity is higher than that of the $40-\mathrm{kW}$ shift catalyst. For this reason it has been selected for the upcoming endurance test. If the claimed performance improvement is verified at the low pressure conditions used in the $200-\mathrm{kW}$ power plant, then the volume of the power plant shift converter could be reduced.

An alternative hydrodesulfurization catalyst that does not require any presulfiding to become active, as does the $40-\mathrm{kW}$ catalyst, was prepared at PSD. The catalyst's activity was evaluated by placing a segmented bed in an electrically heated reactor (see Figure 5.1-6) and determining its ability to decompose thiophane, a sulfur compound frequently used as a natural gas odorant. Measurements of the thiophane concentration were made at the various sample taps using a DOHRMANN microcoulometric sulfur analyzer. Data obtained using this technique was not repeatable, and for this reason the thiophane approach was replaced by measuring the level of hydrogen sulfide, the product of thiophane decomposition. This measurement was taken using KITAGAWA hydrogen sulfide detection tubes. The data is now repeatable and shows that this catalyst has higher activity than the $40-\mathrm{kW}$ catalyst. The testing, however, is not expected to be completed until early January 1984. An HDS catalyst selection for the endurance test will be made at that time.

\section{Subtask 5.2 Fuel Processor Catalyst Endurance Testing}

\section{Objective}

The objective of this subtask is to carry out a 2000 hour endurance test featuring one of each of the catalyst types selected in Subtask 5.1. 


\section{ORIGINAL PAGE IS
OF POOR QUALTTY}

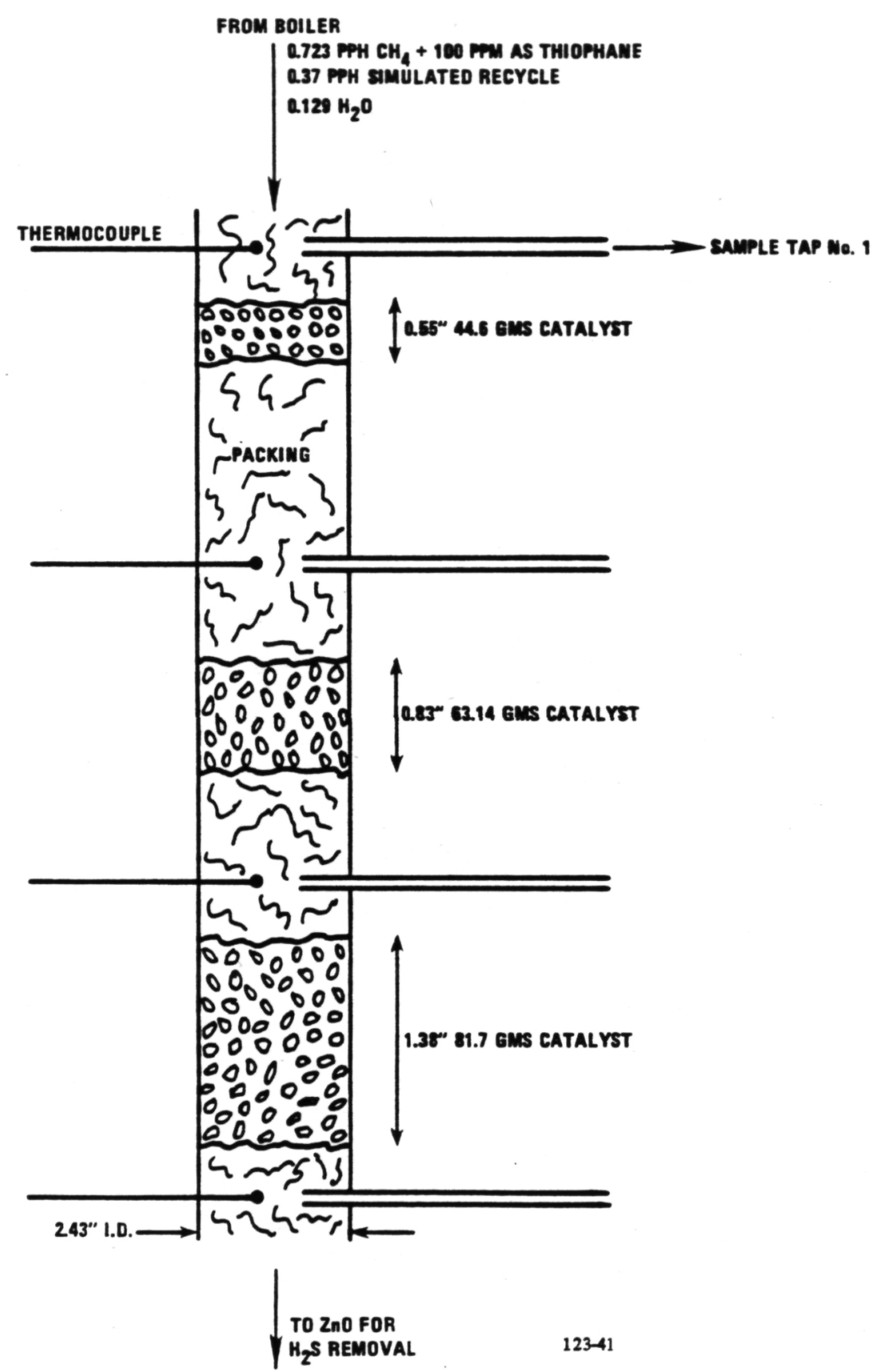

Figure 5.1-6. Subscale HDS Test Reactor Schematic 
$\underline{\text { Summary }}$

A 2000 hour endurance test of a fuel processing catalyst train is planned in order to demonstrate long-term stability of the selected catalysts. The catalyst train is comprised of a hydrodesulfurizer, steam reformer, and shift converter connected in series, as they would be in a power plant. A test stand has been modified to accept the subscale reactors, which have been fabricated. The reforming and shift converter catalysts have been selected, and a supply of them is on hand. Problems measuring gas stream sulfur concentrations in the Task 5.1 hydrodesulfurizer testing have delayed the selection of this catalyst for the endurance test. This has postponed the start of the endurance test until January 1984.

\section{Highlights}

- A test stand has been prepared for the endurance test.

- The reactors have been fabricated and loaded with catalyst, with the exception of the hydrodesulfurizer.

\section{Discussion}

A 2000 hour endurance test of a fuel processing catalyst train is being planned. This test will provide experience with certain catalysts that offer potential benefits relative to the $40-\mathrm{kW}$ catalysts. The endurance train will be comprised of a fuel clean-up section (hydrodesulfurizer/Zno sulfur scrubber), a steam reformer, and a low temperature shift converter. These will be arranged as shown in Figure 5.2-1. The individual vessels have been fabricated and loaded with catalysts selected in subtask 5.1, with the exception of the hydrodesulfurizer, since final selection of this catalyst has been delayed. This catalyst train is planned to operate on a representative pipeline quality natural gas. The throughput will be varied over the anticipated range of the power plant, and gas compositions will be monitored at periodic intervals in order to establish catalyst stability characteristics. 


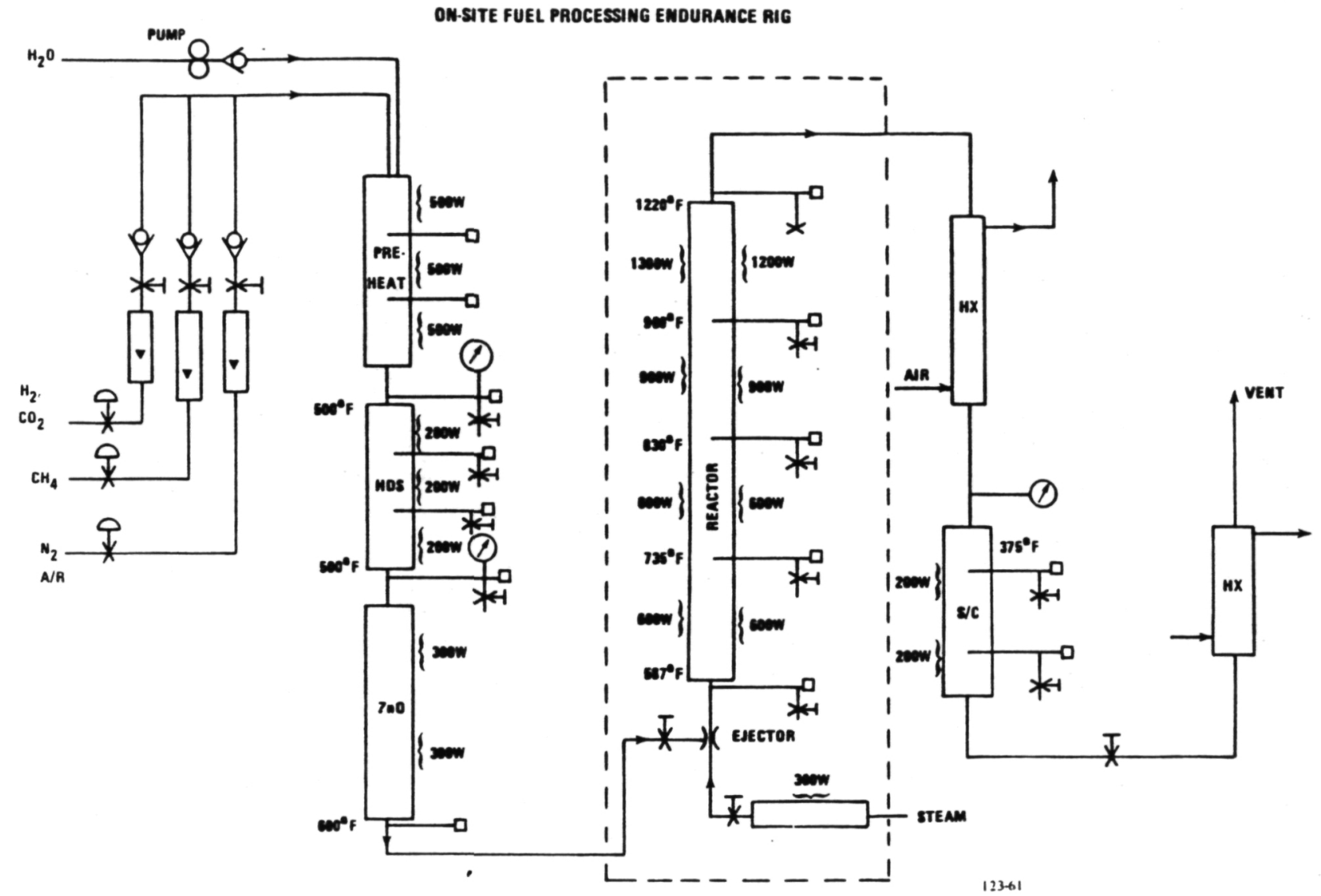

Figure 5.2-1. Catalyst Endurance Train for On-Site Fuel Processor 
The catalyst vessels are designed so that each catalyst type will be subjected to operating conditions similar to those found in the power plant. The reformer was fabricated from a four foot section of 1.25 inch schedule 40 pipe, and contained 1362 grams of HGC-4014 steam reforming catalyst. The shift converter was fabricated out of a 41 inch section of three inch tubing and contained 6808 grams of HGC-4015 shift catalyst. The test stand was designed to operate at fuel flows up to 1.4 pounds per hour.

Subtask 5.3 Verify Reformer Technology

\section{Objective}

The objective of this subtask is to prepare a development reformer for testing.

$\underline{\text { Summary }}$

A tubular configuration for the $200-\mathrm{kW}$ development reformer was selected and analyzed under GRI Contract No. 5080-344-0405. A burner test rig was fabricated, and a commercial burner was purchased and is being evaluated. In addition, a two dimensional flow model of the first of three potential burner arrangements was fabricated, and water flow table testing has begun. An infra-red pyrometer has been purchased and will be evaluated as an alternate means of reformer temperature control. This technique has the potential for higher reliability and stability. Design of the reformer is being addressed in the parallel GRI effort. 


\section{Highlights}

- Selected a seven tube reformer from among five candidate configurations for the 200-kh development reformer design. Performance estimates confirmed that this selection satisfies system performance requirements.

- Prepared a facility for testing a commercial burner and began tests to map burner performance.

- Prepared facility for conducting water table model tests of the burner arrangement.

- Purchased equipment for infra-red pyrometric tube temperature sensing and control.

- Development reformer design is underway under the parallel GRI effort.

Discussion

A development reformer is being designed under the parallel GRI design task. Work done to support this effort has included screening and selection of a reforming catalyst, performance analysis estimates, modification of an existing UTC test facility for testing candidate reformer burners, flow model testing of various burner arrangements, and procurement of an infra-red pyrometer for evaluation as a possible means of reformer temperature control.

Analysis of the proposed seven tube, $200-\mathrm{kW}$ development reformer confirmed that it would meet the required rated power performance level of $92.5 \%$ fuel conversion at $88^{\circ}$ o efficiency over the full expected power range. Performance characteristics are shown in Figure 5.3-1. The tube geometry will be based on the use of standard pipe and tube sizes wherever possible, in order to reduce cost and improve availability. 


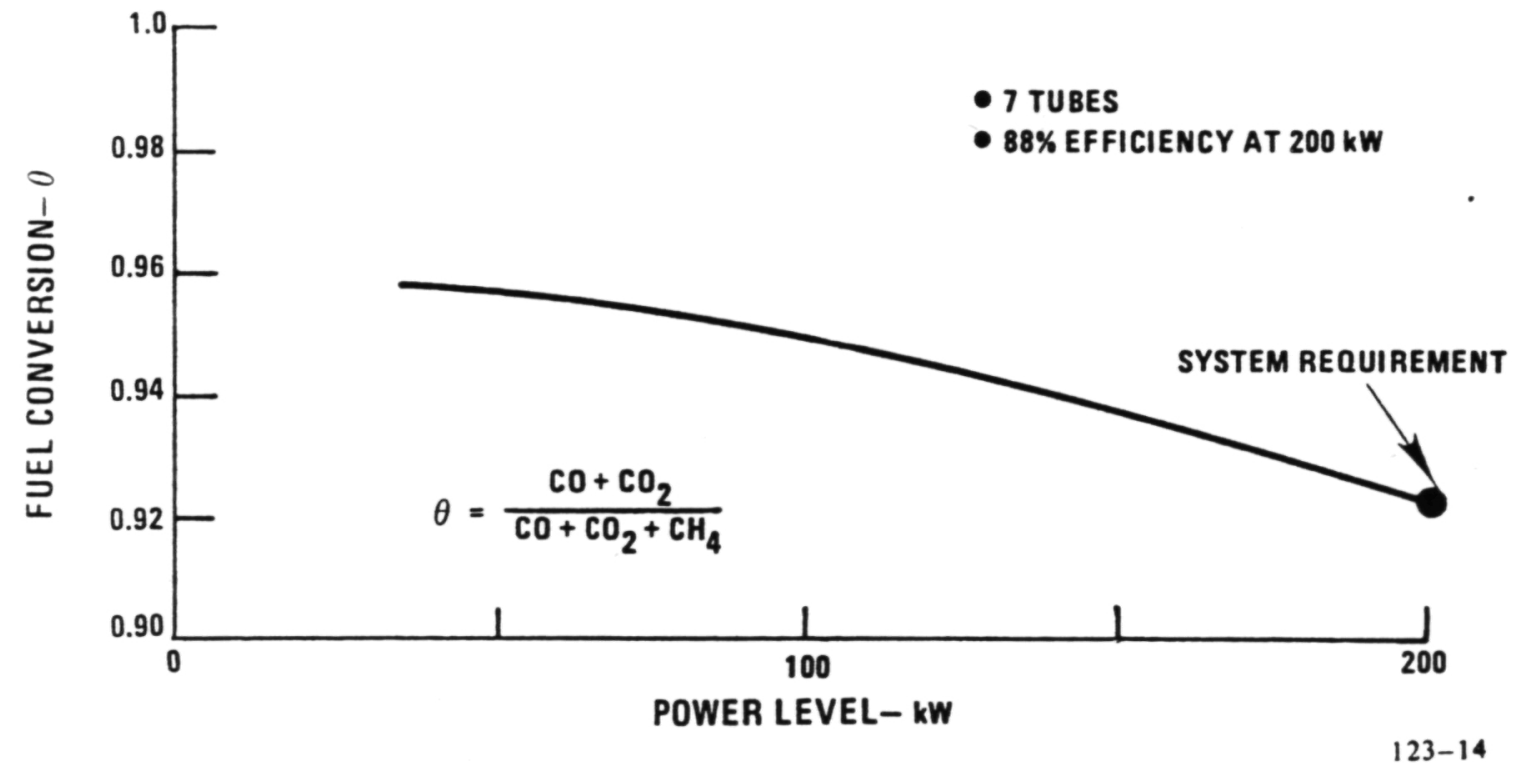

Figure 5.3-1. 200-kW Development Reformer Performance Estimate 
An industrial burner was selected for evaluation in the development reformer, and an existing UTC facility has been modified for testing the burner at $200-\mathrm{kW}$ operating conditions. Figure 5.3-2 shows the test arrangement, and Figure 5.3-3 shows the burner that has been purchased for evaluation. The purpose of this test is to establish the following:

- maximum heat release capability

- air and fuel pressure drop

- capability for start-up on natural gas and steady operation on low BTU anode exhaust gas

- ignition characteristics

- turndown ratio

o operating margin with changing air/fuel ratio, etc. 


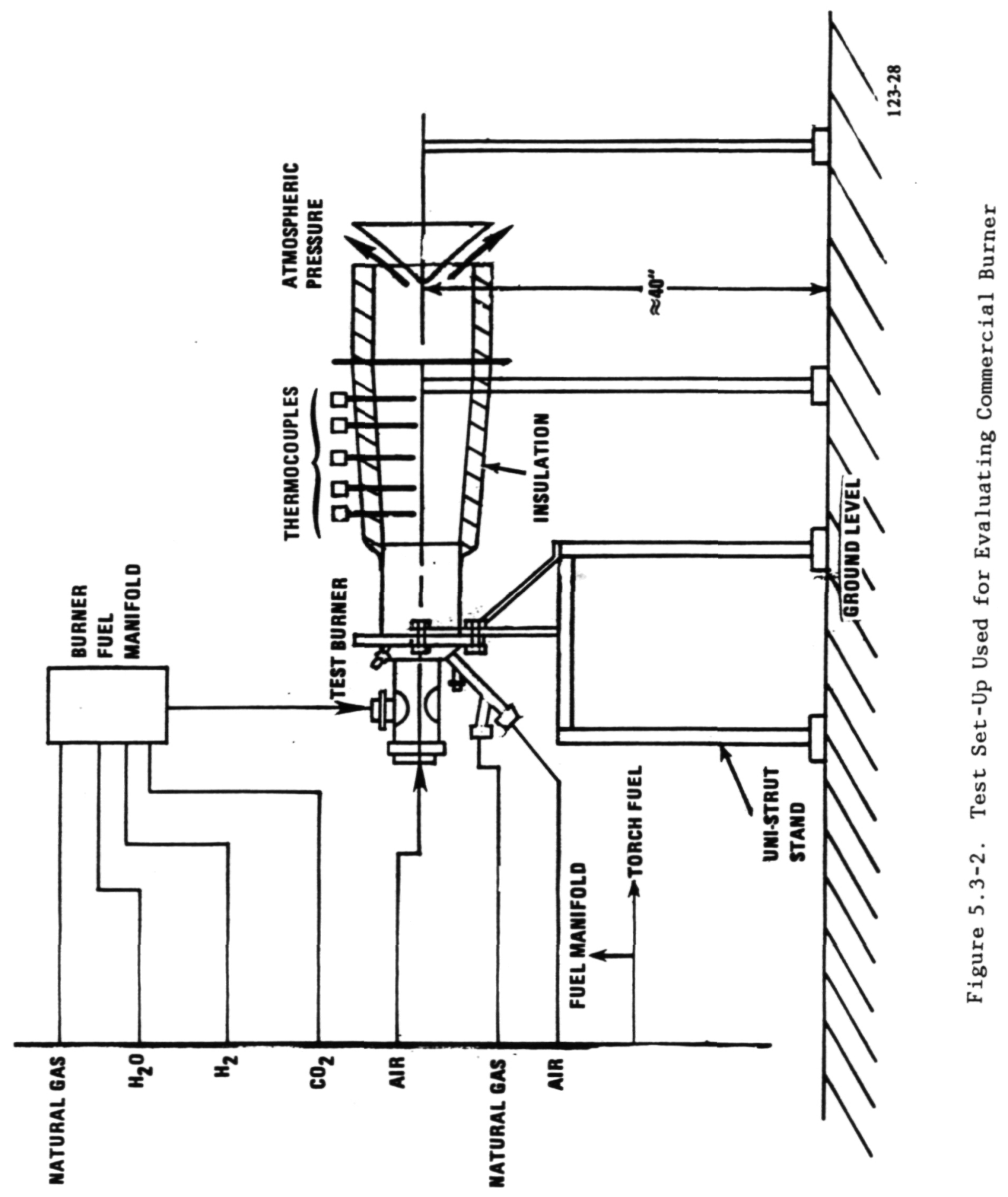




\section{ORIGINAL PAGE IS OF POOR QUALITY}

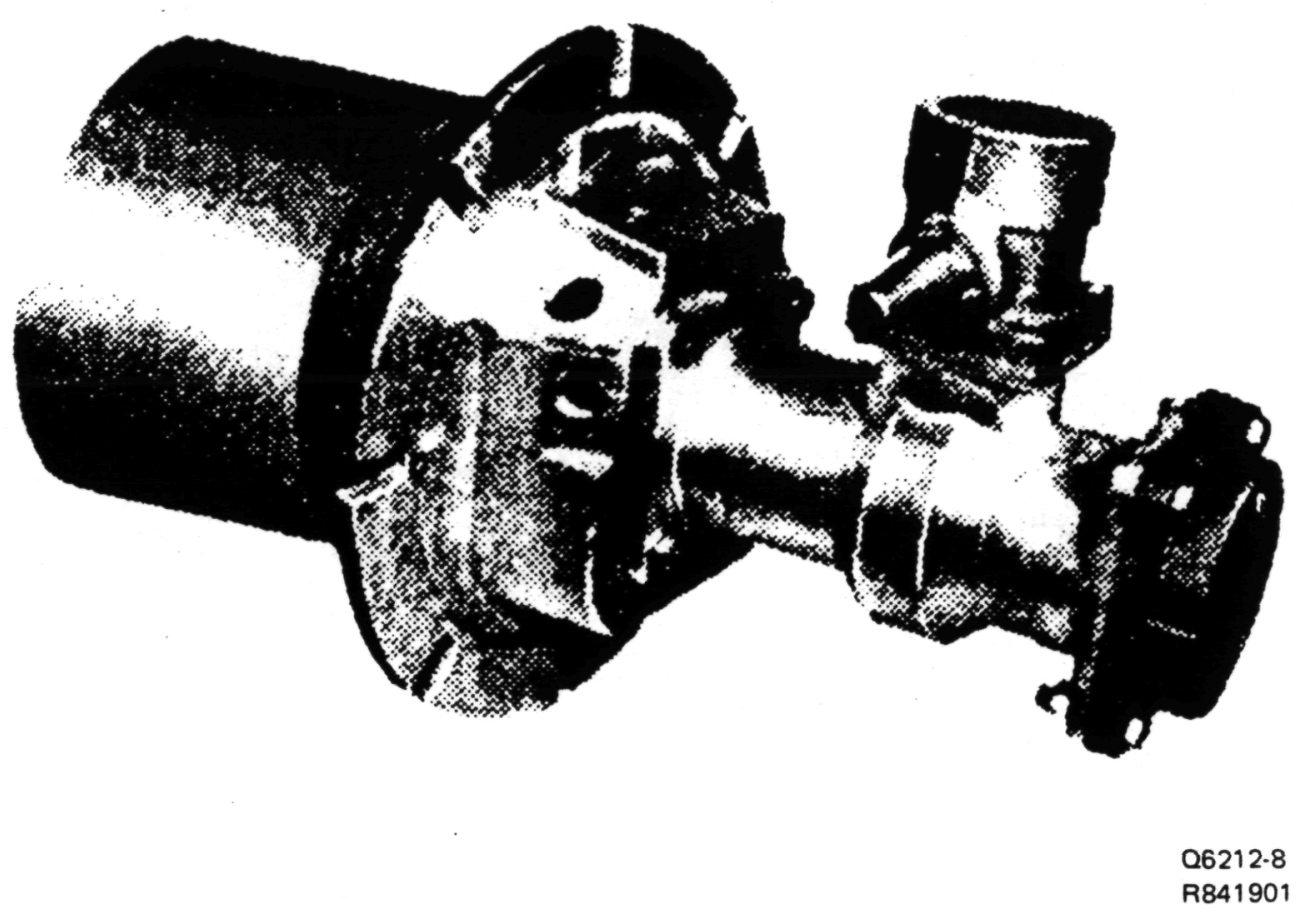

Figure 5.3-3. Commercial Reformer Burner Candidate 
Three potential arrangements for using this burner have been defined:

down fired
- side fired
○ upfired

Water table flow tests of various burner/reactor arrangements are planned to aid in the selection of the optimal configuration. Figure 5.3-4 shows the water table set up with a model of one burner arrangement in place. The objective of these tests is to use a proven water analogy to study the flow distribution provided by each arrangement and to make burner/flow path geometry changes as required. Testing will be conducted using talcum powder as a tracer and pulse photography of individual particles to determine streamline velocities. This will be used to define areas in the burner cavity where flow distribution improvement is required.

An infra-red pyrometer has been purchased for evaluation as a means of controlling reformer temperature. The objective is to develop an alternate, more reliable means of temperature measurement than thermocouples, which are subject to drift with aging. This evaluation will take place during testing of the development reformer. 


\section{ORIGINAL PAGE IS
OF POOR QUALTYY}

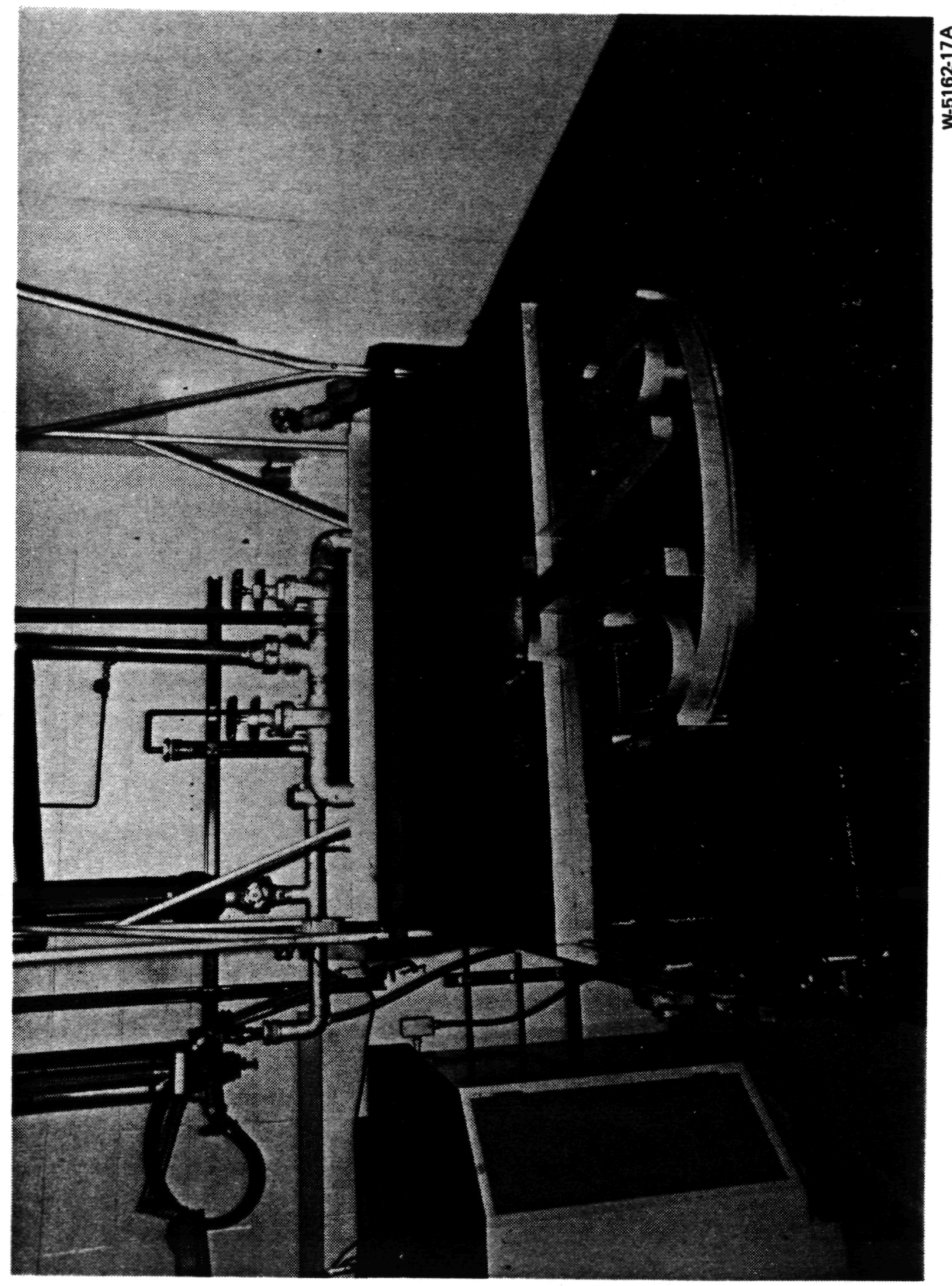

告 
TASK 6 ASSESS PREPROTOTYPE AND VERIFICATION TEST RESULTS 
TASK 6 - ASSESS PREPROTOTYPE AND VERIFICATION TEST RESULTS

\section{Objective}

The objective of this task is to review operating experience with the verification test unit at United Technologies' South Windsor, Connecticut plant and experience with preprototype units located at UTC in South Windsor; in Portland, Oregon; Rockville, Connecticut; and two privately purchased units. The results of this review were assessed to determine whether additional technology development activities or changes in emphasis are required to overcome these power plant reliability deficiencies in future power plants.

\section{$\underline{\text { Summary }}$}

The activities in Task 6 included review of power plant shutdown experience for six early 40-kW power plants. Each unscheduled shutdown was examined to determine the classification of failure. All failures have been addressed by design or procedure changes for the 47 Power Plant Field Test. Program. A number of changes were made to the Technology Development Program activity to develop a basis for design of future power plants that will not be susceptible to these failure causes.

\section{$\underline{\text { Highlights }}$}

- The operating experience with early power plants was reviewed and the unscheduled shutdowns classified by type of cause.

- The failures were reviewed and two changes made to the Technology Development Program to provide an improved reliability base for future power plants. These changes involved institution of activities to investigate coolant loop issues and initiation of an activity to establish guidelines for improved logic card reliability.

- Several other technology program activities are already underway that will provide improved components addressing other failures experienced in the early power plant testing. 


\section{Discussion}

The shutdown experiences of the verification power plant, three DOE/NASA preprototype field test power plants, and three private preprototype field test power plants were analyzed to provide additional reliability information for use in the prototype technology design and development program.

The power plants whose operating histories were included in the data base included:

The verification test power plant. This unit was constructed and tested under DOE Contract No. DE-AC-03-77ET11302 and GRI Contract No. 5010-344-0060 to evaluate improvements on earlier $40-\mathrm{kW}$ power plants that had been built and operated under private funding.

Three preprototype power plants constructed under DOE contract No. DE-ACO180ET17109. One of these units containing design modifications to approximate field test units remained at UTC's South Windsor, Connecticut facility for further development testing. One was installed in Portland, Oregon by Northwest Natural Gas, supplying power and cogenerated heat to a laundry. The third unit was installed by Northeast Utilities in Rockville, Connecticut. This unit supplied power and cogenerated heat for a telephone company switching center.

Two privately purchased units, of the same design as the three units constructed under DOE contract.

These early power plants were operated as field development units to identify improvements to: power plant components, manuals, and training, which would result in improved operating experience for the power plants in the 47 unit field test program. Deliveries under this program began in the Fall of 1983. The 47 Power Plant Program is sponsored by GRI and DOE and managed by NASA under Contract No. DEN3-255. 
The scope of field test experience employed in the assessment is summarized.

\begin{tabular}{|c|c|c|c|}
\hline$\underline{S / N}$ & $\begin{array}{l}\text { Start-up } \\
\text { Date } \\
\end{array}$ & $\begin{array}{l}\text { Hours of } \\
\text { Operation }\end{array}$ & $\begin{array}{c}\text { Operating } \\
\text { Status } \\
\end{array}$ \\
\hline 8218 & $4 / 16 / 83$ & 3217 & Operating \\
\hline 8219 & $9 / 13 / 83$ & 2593 & Deactivated \\
\hline 8220 & $6 / 19 / 83$ & 1375 & Operating \\
\hline 8221 & $3 / 25 / 82$ & 1219 & Operating \\
\hline 8222 & $3 / 25 / 82$ & 972 & Operating \\
\hline
\end{tabular}

The shutdown histories of these power plants were reviewed to determine whether changes in emphasis of existing tasks or addition of new tasks would be appropriate in the Technology Development Program. These changes would be made to ensure development of technology that would improve reliability for future power plants.

Power plant shutdowns were reviewed to determine if they were scheduled or unscheduled. Unscheduled shutdowns were defined as power plant failures and were reviewed further to define primary cause. Failures were then classified into the following categories:

Non-Relevant Failures - Failures arising from circumstances not normally found in the intended application.

Relevant Failures - Failures caused by circumstances or conditions relevant to power plant technology and development.

Process Failure - A failure attributed to a power plant function performed unsatisfactorily by one or more components.

Inadequate Component Failure - A failure caused by a component that satisfies specified design requirements but predictably limits power plant operation.

Human Error Failure - A failure caused by a direct human action. 
Component Failure - A failure caused by a component that meets specified design requirements. Failures of this type are often referred to as random failures.

Non-relevant failures, which represented only about $2 \%$ of the shutdowns reviewed, were excluded from further consideration.

All relevant failures were categorized a second time as either failures during start or failures during operation. For the purpose of this analysis, failure to achieve load or failure within 24 hours of achieving load was defined as a start failure.

Table 6-1 shows the percent of relevant power plant failures by cause. A further review of the failures of these power plants shows that all the failures have been addressed with design changes ( 85 percent) or procedural changes ( 15 percent) for the 47 power plants to be delivered beginning in the Fall of 1983. The operation of these improved power plants will demonstrate whether the changes were effective in resolving the problem.

Tables 6-2, 6-3, 6-4, and 6-5 break down process failures, inadequate component failures, human error failures, and component failures. These tables are then discussed with respect to Technology Development Program effects.

Table 6-2 shows that the process failures are all associated with water system issues. Corrosion products have deposited in flow restrictions which control coolant distribution in the cell stack. This problem has resulted in the largest change in the Technology Development Program. In the GRI Technology Development Program, alternative designs for the flow restrictions and alternative water loop configurations, materials, and approaches are being evaluated in subscale rigs, and the mechanisms of corrosion product deposition are being evaluated. Results of these activities have been used to design cooling system modifications, which are currently being evaluated in the $40-\mathrm{kW}$ power plant design. In addition, work on an alternative cooler is already underway in the Technology Development Program. This cooler does not require flow restrictions. 
Table 6-3 shows power plant shutdowns that were due to inadequate components. These problems are associated with components not meeting the requirements for fuel cell operation. As a result of the deficiencies identified in failures of the early units, revised requirements and modified components have been defined for the 40-kW Field Test Program. The adequacy of these revisions will be verified in the field test and the design information can then be used to select components for future power plants. There are several technology development activities associated with these problem areas.

First, an activity was added to the GRI Technology Development Program to develop guidelines for avoiding logic card problems. Second, inverter control logic and power plant control logic using few parts was already under investigation. This improved logic is based on more highly integrated logic elements that permit use of mass produced hardware for the fuel cell application. Alternative control actuation approach studies to reduce the number of control devices, and evaluations of integrated fuel controls and feedwater pumps with improved design margin are also being evaluated. These activities are expected to reduce failures associated with pumps and valves. Heat exchangers that eliminate concerns with trapped protective coatings are also being pursued in the Technology Development Program.

Tables 6-4 and 6-5 show shutdowns associated with component failures and human errors. These failures have been addressed in the $40-\mathrm{kW}$ field program. Because they involve power plant specific issues, no action is appropriate in the Technology Development Program.

The review of power plant operating experience to identify appropriate changes to the technology program will continue under the GRI Technology Development Contract in the future. 
TABLE 6-1. PERCENT FAILURES BY CAUSE

\begin{tabular}{lc}
\hline Component Failures & $\begin{array}{r}\text { Percent } \\
\text { of all } \\
\text { Failures }\end{array}$ \\
Inadequate Components & 7 \\
Process Failures & 7 \\
Human Errors All Causes & $100 \%$ \\
A & 7 \\
\hline
\end{tabular}

TABLE 6-2. POWER PLANT SHUTDOWNS DUE TO PROCESS FAILURES

1. Water Cleanliness Problems
2. Water Tank Flow Path
Total


TABLE 6-3. POHER PLANT SHUTDOWNS DUE TO INADEQUATE COMPONENTS

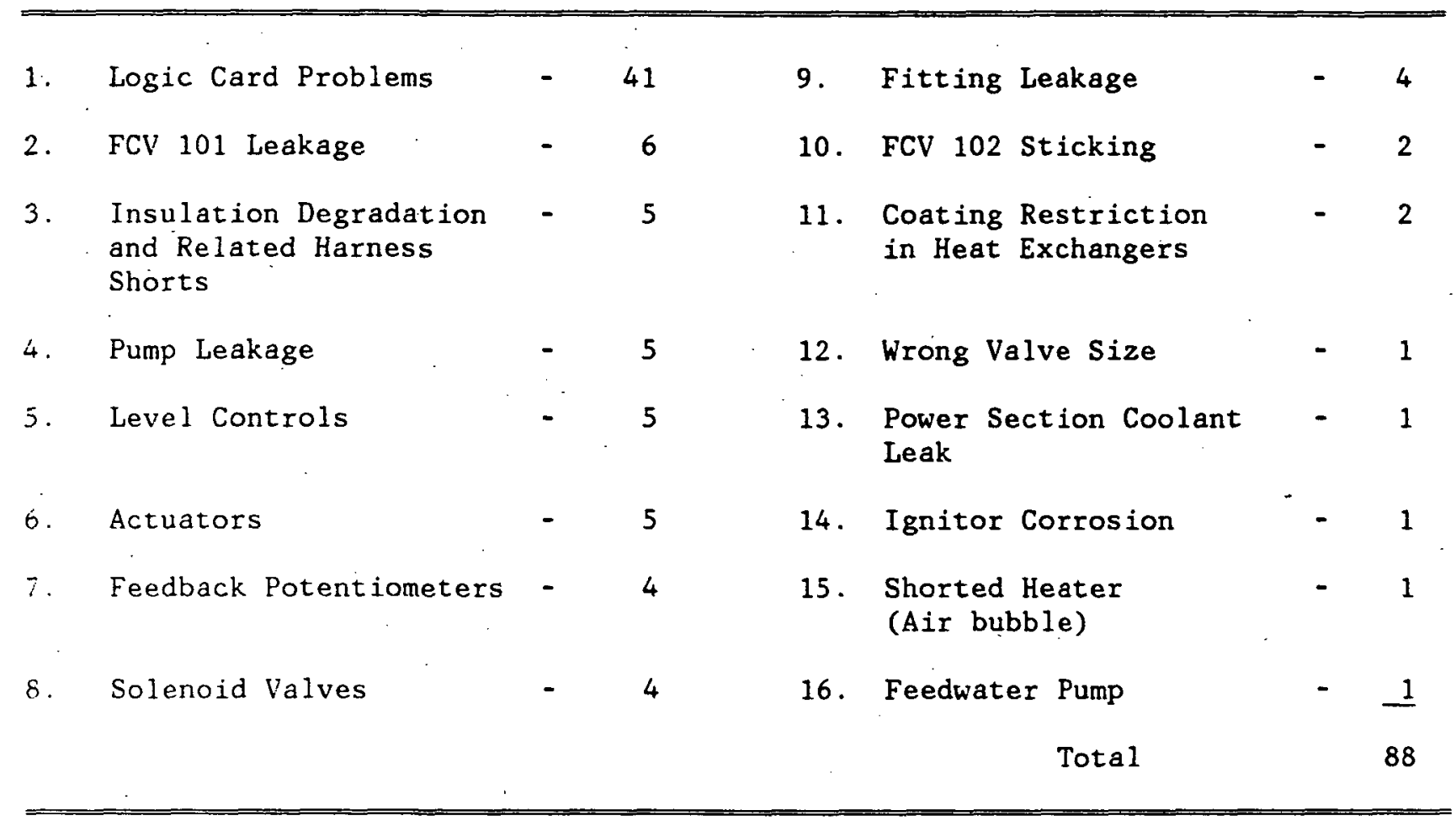

TABLE 6-4. POWER PLANT SHUTDOWNS DUE TO COMPONENT FAILURES

1. Relay Switch

2. Door Switch

3. GCU Switch

4. Fan Notor

5. Fuse

6. Thermal Switch

7. Flow Switch

Total
1

1

1

1

1

2

$\underline{1}$

8 
TABLE $6-5$. POWER PLANT SHUTDOWNS DUE TO HUMAN ERRORS

\begin{tabular}{rlll} 
1. Loose Wires (Assembly) & - & 2 \\
2. $\begin{array}{l}\text { Wire Failures (Related to } \\
\text { Previous Maintenance Action }\end{array}$ & - & 3 \\
3. $\begin{array}{l}\text { Operator Error (GCU Switch } \\
\text { in Wrong Position) } \\
\text { Total }\end{array}$ & - & 9 \\
\hline \hline
\end{tabular}




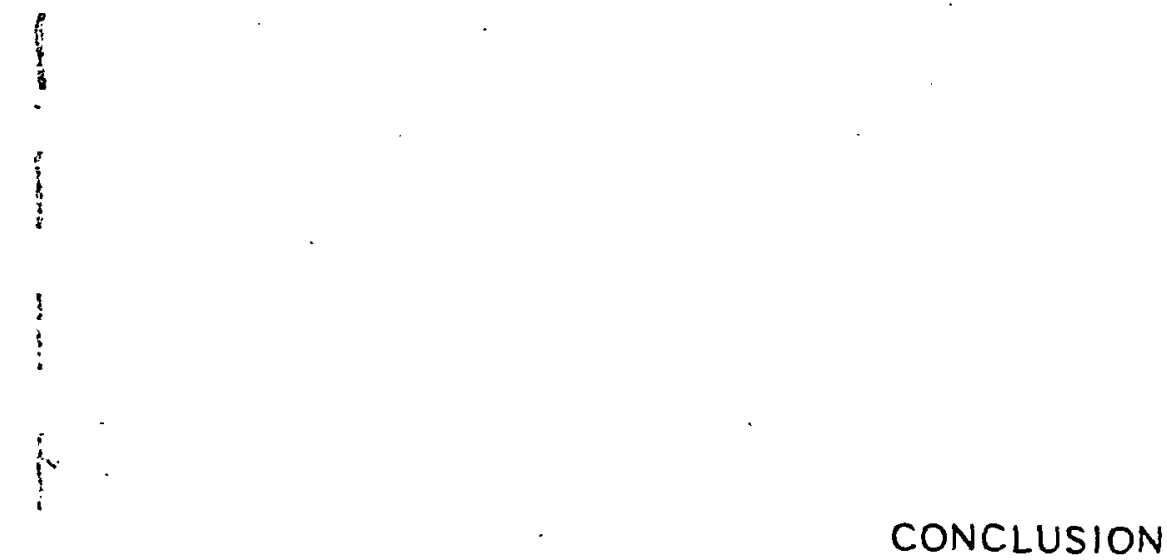


CONCLUSION

Subscale endurance cells were run containing GSB-18 cathodes and HYCAN anodes, which perform within seven millivolts of the program goal (E+20mV) after 2000 hours of testing.

Dual porosity substrate electrodes which are predicted to have a wider electrolyte fill tolerance were evaluated and found to perform equivalently to those using conventional substrates. Control of substrate pore size was found to be improved by blending fibers of various diameters. Although low cost substrate materials have been identified, resulting substrate characteristics are not at the desired levels; therefore, further processing development is required.

An acid condensation zone cell design was developed which has the potential of doubling the time between acid refills. The concept is being evaluated in the short stack currently being evaluated in this program. An encapsulated serpentine cooler design was developed which improves cooling performance, improves the reliability of the cooler assembly by eliminating flow control orifices, and reduces the cost of the cooler. This cooler design is also being evaluated in the program's short stack test.

Three acid addition techniques were evaluated in a laboratory rig, and the spray approach was selected for full-scale verification testing. The spray acid addition approach was tested on a $270-c e 1140-\mathrm{kW}$ stack. This technique will be further evaluated on the short stack when it reaches 5000 hours of testing.

An advanced 30 -cell short stack was tested for 2,900 hours at $400^{\circ} \mathrm{F}$ atmospheric pressure and $200 \mathrm{ASF}$. The major features of this stack are dry mix and wet mix GSB-18 cathodes, encapsulated serpentine coolers, acid condensation zone, and acid refill capability. The performance of this stack is 5-10 $\mathrm{mV}$ below E-line and is decaying at E-line rate. 
An inverter bridge design was established with full power efficiency of $94.8 \%$, as compared to a baseline of $93 \%$. The proposed design is a two-bridge $200-\mathrm{kW}$ inverter with auxiliary commutations for surge circuitry and a low loss output transformer. A bridge coolant study resulted in a decision to select forced air/heat sink cooling for the design. A $200-\mathrm{kW}$ brassboard inverter was designed in the complementary GRI program, and vendor fabrication was completed in this program by December 31, 1983. The bridge vendor fabrication completion is scheduled for January 1984.

A commercial Teflon ${ }^{\circledR}$ coated heat exchanger was successfully evaluated as the acid condenser for the $200-\mathrm{kW}$ on-site power plant. The specific cost of this unit $(\$ / \mathrm{kW})$ is estimated to be $1 / 5$ that of the $40-\mathrm{kW}$ acid condenser. In addition to water cooling, acid condensation approaches were successfully evaluated as a backup for the condensate heat exchanger.

Several reforming catalysts were identified as having less than $35 \%$ of the pressure drop of the baseline catalysts, with near equivalent conversion. These catalysts allow for a simpler development reformer design. Reformer, shift converter, and hydrodesulfurizer catalysts will be selected in 1984 for a 2000 hour endurance test, to verify the catalyst selections. The design for the development reformer has begun under the parallel GRI On-Site Technology Developmental Program. A commercial búrner and infrared pyrometer for temperature sensing and control have been obtained for use in the development reformer tests.

Shutdown experiences from the verification power plant, three DOE preprototype power plants, and two private preprototype power plants were reviewed. A number of changes to the Technology Development Program were made as a result of this review. 


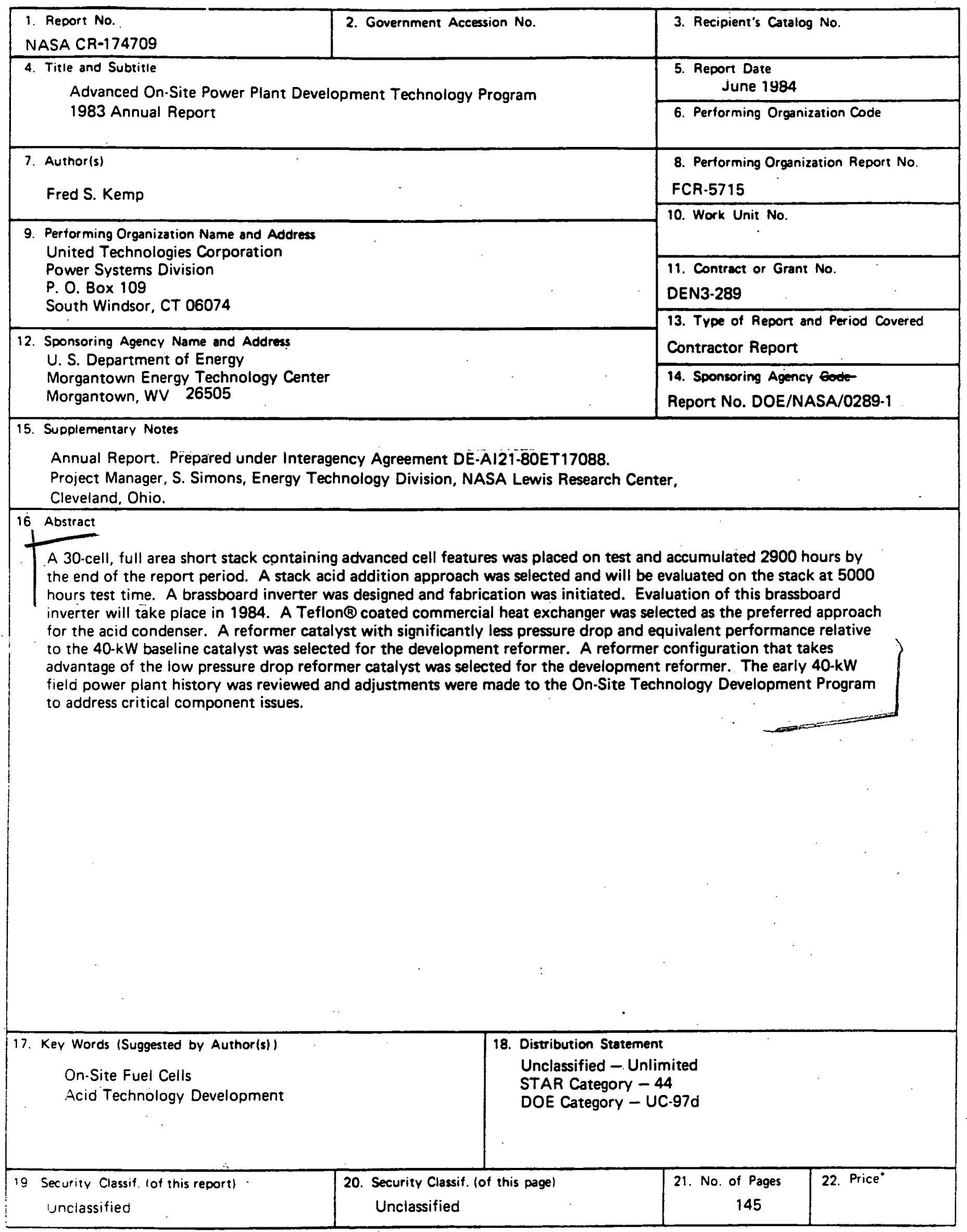

- For sale by the National Technical Information Service, Springfield. Virgina 22161 